Florida International University FIU Digital Commons

FIU Electronic Theses and Dissertations

University Graduate School

3-15-1977

\title{
Correspondence course for travel counsellors : hospitality industry project
}

Thomas Ward Calnan

Florida International University

DOI: $10.25148 /$ etd.FI14052546

Follow this and additional works at: https://digitalcommons.fiu.edu/etd

Part of the Hospitality Administration and Management Commons

\section{Recommended Citation}

Calnan, Thomas Ward, "Correspondence course for travel counsellors : hospitality industry project" (1977). FIU Electronic Theses and Dissertations. 1982.

https://digitalcommons.fiu.edu/etd/1982

This work is brought to you for free and open access by the University Graduate School at FIU Digital Commons. It has been accepted for inclusion in FIU Electronic Theses and Dissertations by an authorized administrator of FIU Digital Commons. For more information, please contact dcc@fiu.edu. 
CORRESPONDENCE COURSE FOR TRAVEL COUNSELLORS $-$ 
CORRESPONDENCE COURSE FOR TRAVEL COUNSELLORS

by

THOMAS WARD CALNAN

. HOSPITALITY INDUSTRY PROJECT

PRESENTED TO THE FACULTY OF THE

SCHOOL OF HOTEL, FOOD AND TRAVEL SERVICES

OF FLORIDA INTERNATIONAL UNIVERSITY

IN PARTIAL FULFILJMENT OF THE REQUIREMENTS

FOR THE DEGREE OF

MASTER'S OF SCIENCE

HOTEL AND FOOD SERVICE

FLORIDA INTERNATIONAL UNIVERSITY

MARCH 15, 1977 
Table of Contents

I INTRODUCTION

Purpose of the Project 1

Origin of Project

Canadian Institute of Travel Counsellors 3

Ryerson Polytechnical Institute 3

Structure of the Programme 5

Objectives of the Programme 5

Course Materials 6

Assignments 6

Certification $\quad 7$

Membership in CITC $\quad 7$

Scheduling of Work Time 8

II ELEMENTS OF RETAIL PRACTICE AND TOURIST DESTINATIONS

Unit 1: Project 10

Lesson 1: Theory of Tourism 11

Lesson 2: Travel Counselling and Travel

Agencies 12

Lesson 3: Travel Documents 25

Lesson 4: Controls and Reference Manuals 28

Lesson 5: Travel Insurance 37

Lesson 6: Legal Responsibilities 39

Lesson 7: Professional Ethics and Standards 42

Lesson 8: Office Procedures 45

Lesson 9: World Geography 49

Lesson 10: Travel Knowledge - General 60

Lesson 11: Canadian Travel Destinations 64

III AIRLINE TARIFFS, FARES AND TICKETING

Unit 2: Project $\quad 67$

Lesson 1: Domestic Route Structures 68

Lesson 2: North American Edition Official Airline Guide (NAOAG) 80

Lesson 3: International Route Structures 84

Lesson 4: International Air Transport Association (IATA)

Lesson 5: International Edition Official Airline

Guide (OAG) 88

Lesson 6: IATA - Reading the Air Tariff I 91

Lesson 7: Reading the Air Tariff II 95

Lesson 8: Reading the Air Tariff III 98

Lesson 9: Reading the Air Tariff IV 100

Lesson 10: Reading the Air Tariff V 103

Lesson 11: Air Traffic Conference of America (ATC) 105

Lesson 12: Airline Terms and Definit'ions 107

Lesson 13: The 24 Hour Clock System; Computing

Time, Flying and Elapsed

Lesson 14: Flight Reservations, Computer

Reservation Systems 
Lesson 15: Ticketing ${ }^{\circ}$

Lesson 16: Ticketing II

Lesson 17: Miscellaneous Charges Order (M.C.O.)

Lesson 18: Charter Services, Taxes on Aire Transportation, Credit Card Sales, Airline Equipment and Reference Material

Sample CITC Qualification Examination Questions 125

IV SURFACE TRANSPORTATION AND TOUR PLANNING

Unit 3: Project

Lesson 1: Introduction to Ocean Travel 131

Lesson 2: Selling the Cruise 137

Lesson 3: Selling the Cruise II and Nautical Terms 140

Lesson 4: Rail Service in North America 143

Lesson 5: Passenger Rail in Europe and Britain 146

Lesson 6: Surface Transportation and Tour Planningl51

Lesson 7: Introduction to Types of Tours 154

Lesson. 8: Inclusive Tour Charters I 159

Lesson 9: Inclusive Tour Charters II 161

Lesson 10: Tour Operators 164

Lesson 11: Product Analysis and Costing of Tours 167

Lesson 12: Airline Promotion of Tours and Reference Materials 173

Sample CITC Qualification Examination Questions 176

$\mathrm{V}$ TECHNIQUES OF SELLING TRAVEL; HOTELS AND RESORTS

Unit 4: Project

Lesson 1: Understanding the Client 195

Lesson 2: Salesmanship 197

Lesson 3: Telephone Sales 201

Lesson 4: Product Knowledge and Success in Sales 204

Lesson 5: Travel Promotion and Public Relations 206

Lesson 6: The Hotel Industry 209

Lesson 7: Hotel Rates and Deposits 211

Lesson 8: Hotel Standards, Grading and Quality 215

Lesson 9: Hotel Reservations and Commissions 217

Lesson 10: Hotel Terminology 222

Sample CITC Qualification Examination Questions 225 
CORRESPONDENCE COURSE FOR TRAVEL COUNSELLORS

\section{INTRODUCTION}

\section{Purpose of the Project}

The purpose of this paper is to produce a travel counselling course which could be subscribed to by students from Canada and abroad, which, upon completion, would qualify them to work in a travel agency.

\section{Origin of Project}

A request was made by the Canadian Institute of Travel Counsellors of Ontario, C.I.T.C., to the Hotel, Restaurant and Institutional Administration Department of Ryerson Polytechnical Institute, Toronto, Ontario, to produce a correspondence course that would prepare a student to write the C.I.T.C. Qualification Examination. This paper was commissioned to fulfil that request.

An agreement was reached between the Canadian Institute of Travel Counsellors of Ontario and Ryerson Polytechnical Institute by which Ryerson would operate the program under the Food, Restaurant and Institutional Administration Department with students qulaifying for a Ryerson Diploma in Travel Counselling upon successful completion of the course and obtaining a passing grade in the C.I.T.C. Qualification Examination. 
The estimated cost to the student to enroll on the Travel Counselling Programme would be $\$ 500.00$ which would Include:

a) the Four Unit Correspondence Course

b) the text "Principles and Procedures of Travel Counselling" published by the Canadian Institute of Travel Counsellors of Ontario, 1976, Toronto.

c) "A Study of the Inclusive Tour Charter Industry in Ontario". Thomas W. Calnan, Ryerson PolyTechnical Institute, 1976, Toronto.

d) "It Will Help If You Know". Air Canada, 1975, Montreal.

e) "Building Tariff Skills", Units 1 to 4, Pan American Airways, 1974, New York.

f) Travel Agents U.S.A. Transportation Guide, 1975-76, U.S. Department of Commerce, 1975, Washington D.C.

g) Complete Instructions, North American Edition Official Airline Guide, The Reuben H. Donnelley Corporation, 1976, Oak Brook, Ill.

h) Complete Instructions, Worldwide Edition, Official Airline Guide, The Reuben H. Donnelley Corporation, 1976, Oak Brooks, Ill.

i) Complete Instructions, Worldwide Tour Guide, The Reuben H. Donnelley Corporation, 1976, Oak Brook, IIl. 
Canadian Institute of Travel Counsellors

The Canadian Institute of Travel Counsellors was incorporated by charter in the Province of Ontario in September 1968. It is an organization of individual travel counsellors presently numbering about 1,100 men and women and was founded:

(1) to elevate the status and increase the prestige of persons engaged in the travel industry in Canada by extablishing higher educational and professional standards in the travel agency field, and

(2) to develop and administer formal educational and training programms designed to raise the level of individual agent competence in pertinent fields of knowledge.

The Institute also represents its members in relationship with the public, the government and other travel industry associations. As well, the Institute endeavours to create and enforce regulations which are designed to protect the public from any possible malpractice by members of the travel industry. (Appendix A)

\section{Ryerson Polytechnical Institute}

The Hotel, Restaurant and Institutional Administration program at Ryerson Polytechnical Institute sarted in 1952, and is the oldest hospitality school in.Canada. Since its inception the program has been a major supplier of managerial 
talent to the hospitality industry in Canada.

The school currently offers a three year diploma program and a four year degree program both of which have attracted a large number of foreign students. The result has been an enhanced reputation in Canada and abroad.

The campus is located in the heart of metropolitan Toronto, with many of the nation's leading hospitality outlets in the immediate proximity of the Institute. This accessibility enhances the students' opportunities to blend into the business community and facilitates the numerous visits and lectures received from top industrial personnel. The hospitality programs have expanded to incorporate tourism and travel. The introduction of the Correspondence Program for Travel Agents is one more step of the expansion policy to meet all the educational needs of the hospitality industry • 


\section{Structure of the Programme}

This correspondence programme in travel counselling consists of four units. Each of these units contains ten to eighteen lessons which have a set of questions to be completed and returned.

The four units contained in the Travel Counselling Correspondence Programme are:

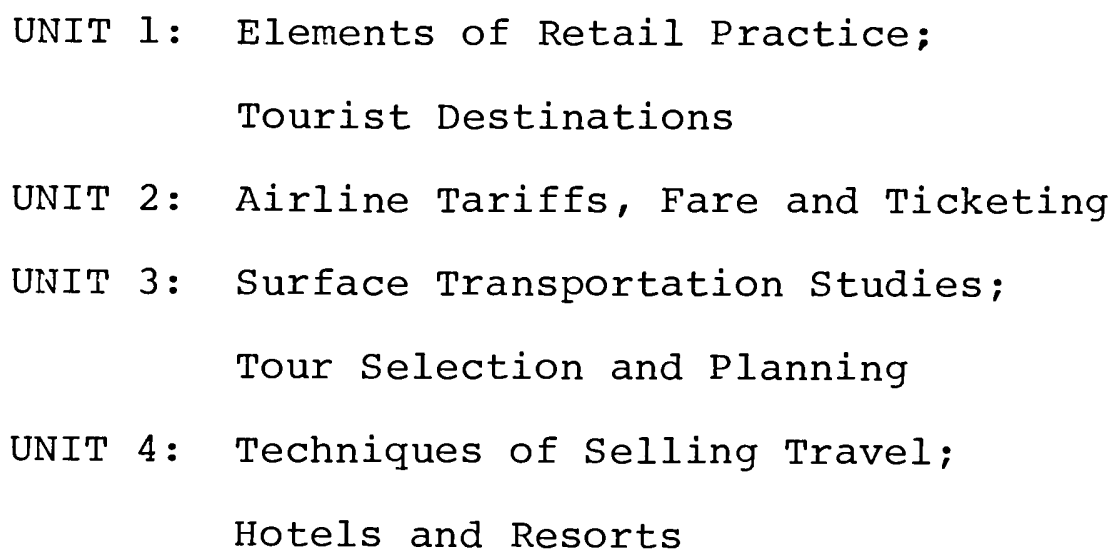

Objectives of the Programme

This C.I.T.C. Travel Counselling Programme is structured to give the student a broad, yet detailed, knowledge of all of the practical subjects related to travel counselling and travel agency operations. In concept and execution, the programme has as its objective the training of travel counsellors who will enter the job market well equipped to accept meaningful employment within the travel industry. Toward this end, the course content and the counselling skills are particularly attuned to serve the needs and wants of Canadian travellers and tourists. 
Each of the four units is directly related to the basic textbook; Principles and Procedures of Travel Counselling, 3rd edition, published by the Canadian Institute of Travel Counsellors of Ontario, 1976.

In addition to the textbook, there are Instructor Notes wherever it is necessary to clarify the information in the text. These notes play the role of the classroom teacher, and are sent to help the student determine what the instructor wishes to emphasize.

The student is expected to make use of reading material that is available in the community through libraries, newspapers and travel agencies.

Stress is placed on the importance of the student's own efforts at building up lesson notes. These are built around the Instructor Notes which will direct, point by point, to the reference sources from which the material can be obtained. The student's lesson notes will be very valuable at examination time. They should provide a complete review of what has been covered and make it unnecessary to reread in detail all the books and materials that have been studied during the term.

\section{Assignments}

Every lesson is accompanied by a set of questions which take the place of classroom participation. All assignments and questions are returned to Ryerson Polytechnical Institute 
where they are marked and returned with corrections. A student does not need to wait for the answers to be returned before continuing on with the next lesson.

In addition to the end-of-lesson questions, the completion of a major assignment is a requirement of each unit. This project is done throughout the course and serves the purpose of allowing the student to obtain an overview of the programme unit.

\section{Certification}

A letter of Completion will be issued by Ryerson Polytechnical Institute on successful completion of each of the four units in the Travel Counselling Programme.

The C.I.T.C. Qualification Examination is written in May and October. Students achieving at least $65 \%$ of the total marks obtainable will be granted pass standing. Students achieving $85 \%$ or more of the total marks obtainable will be granted "Honours Graduate" standing.

The C.I.T.C. Diploma in Travel Counselling is awarded to students who successfully complete the four units of the C.I.T.C. Travel Counselling Correspondence Programme and obtain a passing grade in the C.I.T.C. Qualification Examination.

Membership in the Canadian Institute of Travel Counsellors

Graduates who have passed the qualification examination and who have a minimum of one year of full-time work exper- 
ience at a registered travel agency or travel wholesaler will be eligible for membership in the Canadian Institute of Travel Cousellors as a Certified Travel Counsellor and entitled to use the designation C.T.C. after their name.

\section{Scheduling Work Time}

A correspondence course has the advantage of allowing a student to choose the time to be spent on the programme, however, it is recommended very strongly that the Weekly Personal Timetable be completed.(Figure 1) Setting up regular hours and treating them as class attendance will be helpful in completing the programme successfully. 
WEEKLY PERSONAL TIMETABLE

\begin{tabular}{|c|c|c|c|c|c|c|c|}
\hline TIME & MON & TYES & WED & THURS & FRI & SAT & SUN \\
\hline $8 \mathrm{a} \cdot \mathrm{m}$. & & & & & & & \\
\hline 9 a.m. & & & & & & & \\
\hline $0 \mathrm{a} . \mathrm{m}$ & & & & & & & \\
\hline $1 \mathrm{a} . \mathrm{m}$. & & & & & & & \\
\hline 12 noon & & & & & & & \\
\hline 1 a.m. & & & & & & & \\
\hline $2 \mathrm{p} \cdot \mathrm{m}$. & & & & & & & \\
\hline 3 p.m. & & & & & & & \\
\hline 4 p.m. & & & & & & & \\
\hline 5 p.m. & & & & & & & \\
\hline 6 p.m. & & & & & & & \\
\hline 8 p.m. & & & & & & & \\
\hline 9 p.m. & & & & & 0 & & \\
\hline 10 p.m. & & & & & & & \\
\hline 11 p.m. & & & & & & & \\
\hline
\end{tabular}


II UNIT 1: ELEMENTS OF RETAIL PRACTICE AND TOURIST DESTINATIONS

Unit 1 consists of eleven lessons and a Unit Project. The following materials are needed in order to complete the Unit:

1. Instructor Notes

2. Principles and Procedures of Travel Counselling

3. TIM Manual, October, 1975 Edition

4. Two Canadian Passport Application For "A".

\section{Unit 1: Project}

Start a filing system of your own for fifteen tourist destinations. The choice of destinations is your own. (See Lesson 9 for Tourist Bureau Addresses) The purpose of the file is to be a quick source of information, therefore, a list comparing hotel facilities compiled by you would be more useful than a brochure from each hotel.

Newspaper articles, clippings, etc., would be mounted on paper for ease of handling.

A bibliography of all sources of information should be kept and submitted.

It is recommended that the student obtain and study the weekly newspaper travel supplements for the duration of the course.

The project is to be completed over the period taken to do Init 1. It is to be submitted with the last lesson. 
Marks will be awarded for the following:

1. completeness of information on destinations

2. usefulness of project as an information resource

3. neatness of presentation

4. indiction of continuity of travel reading throughout the course - i.e., Travel sections from newspapers, articles from magazines

5. completeness of Bibliography.

This project will be useful in completing exercises in the following units.

LESSON: $\quad$ One

TOPIC: $\quad$ Theory of Tourism

OBJECTIVES: The student will define Tourism and state the reasons for its growth and importance.

REFERENCES: Principles and Procedures of Travel Counselling Page 1 - 5 (Sections 1 - 7)

INSTRUCTOR'S NOTES :

Read Section I:

The International Union of Official Travel Organizations (IUOTO). This organization was renamed the World Tourism Organization (WTO) in November, 1974. It is an international body with representation from member governments and a special relationship to the United Nations. The W.T.O. gathers, translates and communicates statisitics and information to members; it carries out an education programme and holds seminars on the problems affecting international tourism. 
Read Section 2:

The UN definition of a tourist does not take into account the vast movement of persons resident in a country to other parts of the same country, for the purposes given in (a) and (b). This type of traffic is known as domestic tourism and would account for such cases as a resident of Toronto who journeys to Banff for a vacation.

Read Section 3 and 4:

The most recent advance in air transportation was the introduction of the supersonic Concorde aircraft which cut travel time to one half of the time taken by regular jet services. Study the diagram on page 2 - World and International Passenger Traffic Forecasts.

Read Section 5:

Disposable income and discretionary dollar are two economic terms with slightly similar use. Disposable income is the money a person has to spend after paying taxes, in otherwords, a person's take-home pay. Discretionary dollar is used to indicate the balance of money a person has remaining after paying all bills and meeting all financial commitments. This money can be saved or spent as they choose. A man who earns $\$ 200.00$ per week and has $\$ 50.00$ of it left after paying taxes, bills, etc. can be said to have $\$ 50.00$ discretionary income. 
The travel agent provides his customers with many services. Some of these services come from the agent's own resources and experience, such as information on required documents, climate, customs, restaurants, etc. Others are services offered on behalf of someone else, such as an airline, steamship, hotel or railroad. When a customer buys an airline ticket from a travel agency, he pays the same amount as he would had he gone to that airline's own ticket office. For the customer, the advantage in going to the travel agent is that he saves time and effort because he is able to choose from a wide variety of airlines or other services.

But, if the travel agent does not charge a fee over and above the airline's or hotel's regular price, how does he make money? The travel agent is officially recognized by the various airlines, steamships, hotels, railroads, etc. These companies are referred to as INDUSTRY PRINCIPALS. The travel agent is authorized to sell their services and, in effect, he is a part of their sales team. When he sells the services of an industry principal, that company pays the travel agent a commission. This commission is usually a fixed percentage of the price of the service sold.

Here's a quick example of how this commission plan works. Your customer wants to take a cruise in the Caribbean. The fare charged by the steamship company is $\$ 200.00$. That company will pay the travel agent a $10 \%$ commission for this sales amounting to $\$ 20.00$. It is important to note that the steamship company, airline etc., does not pay the travel agent 
anything until a specific service is sold. The agent is not "salaried" in any way by those industry principals.

Commissions, however, are not the only source of income for the travel agent. In some instances he may add a service charge. For example, the travel agent may have a client who desires a specially tailored trip. The agent must seek out and make arrangements for appropriate hotels, night clubs, restaurants, sightseeing tours, etc., and bring them together in a well organized fashion. The time and experience required of the agent to make such arrangements sometimes necessitate a service charge. The total charge may be slightly higher or lower than if the traveler had made all the arrangements himself. But then, how many travelers have first-hand knowledge of the world's hotels, restaurants, and attractions, not to mention the time and knowledge needed to actually set up the arrangements. As you will see in the following lessons, however, many services offered, ordinary scheduled air travel, for example, are never "marked up" by the travel agent.

\section{Who Can Be A Travel Agent?}

Depending upon the area in which you live, there may be one, a few, or many travel agencies. Some may be large, with a big office and many employees, others may be smaller with only two or three employees. Some offer a broad, complete travel service, others may emphasize a specialty or appeal to certain groups or people. But every agency is owned or managed by a professional travel agent, an individual who, 
because of his superior skills, knowledge and adherence to certain standards, has been appointed by the various industry principals as their agent.

In general, the travel agent must meet these requirements :

1. operate in a fixed location that is attractive and accessible to the general public. In most cases this location is for the sole purpose of promoting and selling travel.

2. demonstrated his desire and ability to promote travel in a professional manner.

3. adequate capital.

4. a competent staff to carry out his duties and responsibilities.

The actual list of requirements is much longer and more complex than we have stated here. But the point is, not everyone can become a travel agent. The agent for whom you will work has earned his place in the travel industry through his hard work, professional skills, and by meeting high standards.

More than half of the accredited agents in the United States and Canada are members of the American Society of Travel Agents. They have demonstrated the highest degree of professionalism by adhering to the Society's "Principles of Professional Conduct and Ethics". They insure competence and integrity in relations with the public, their fellow agents and the entire travel industry. As a new employee in a travel agency, you should adhere to these principles, especially those 
having to do with your relations with the public.

The following is a summary of the Society's "Principles of Professional Conduct and Ethics":

1. It is the duty of the travel agent to protect the public against any fraud, misrepresentation, or unethical practices in the travel agency industry. He should endeavour to eliminate any practices which could be damaging to the public or to the dignity and integrity of the travel agent's profession.

2. It is the duty of the travel agent to keep himself fully informed on all phases of domestic and international travel in order to be in a position to give clients truly professional travel advice and to secure for them the best possible travel services and accommodations.

3. The travel agent should ascertain all pertinent facts concerning every tour, transportation, accommodation, or other travel service offered to the public so that he may fulfill his obligation to inform his clients accurately about the services he sells and the costs involved.

4. Travel agents shall consider every transaction with a client to be strictly confidential unless the client specifically authorizes disclosure.

Where Will You Fit In?'

As you look around your office, you will see that your 
employer has invested a considerable sum in his agency. He has office furniture, expensive machines, volumes of reference materials, a monthly rent to pay, and your salary. This might make you feel insignificant at first, until you realize that on the average, salaries make up $60 \%$ of your employer's costs. That in itself says a lot about your importance as a travel agency employee. But your value goes even farther. A travel agency is in the business of providing services to people who want to travel. And only you can take a customer's ideas or dreams and turn them into a successful business trip or a wonderful vacation he will remember forever. The books and machines and attractive office are merely tools which can come to life in your hands. You are, in fact, the most important asset your employer has.

Needless to say, you also have important responsibilities, to the public and to your employer. Both are counting on you to provide friendly service and efficient travel arrangements. What are some of the duties you will perform that have such an important effect? The number and scope will vary from one agency to another but the basic duties are:

1. OFFICE SALES: This includes greeting the customer, determining his desires for travel, planning and presenting possible travel arrangements, assisting him in making the decisions, and carrying out the details. If this soundș like you would be doing everything, you are almost right. But many agencies divide these functions up between two or 
more employees.

2. TELEPHONE SAIJES: This is very similar to office sales except that the initial, and sometimes the only, contact is by telephone.

3. RESERVATIONS, FARES AND TICKETING: This is the "technical" side of the travel agent's duties and includes making transportion and hotel reservations, writing tickets and vouchers, and computing fares and charges. Some of this is done by telephone, talking to airline and steamship reservation offices and hotel sales representatives. You will also use transportation schedules, guides and fares tariffs. A large portion of this course is devoted to these subjects and we cannot overemphasize their importance Your salesmanship and good service are of little value if you put your customer on the wrong flight because you misread the schedule.

4. CLERICAL: Another very important area. In order to send people all over the world, a travel agent needs a wealth of information; pamphlets, brochures, schedules, correspondence, reports etc. But if you cannot find this information when you need it, it is of little use. The industry has developed certain methods of keeping such information current and readily available. We will discuss these later in this lesson. 
Secretarial duties are also important, particularly typing. A travel agency does a large amount of corresponence, letters to clients, sales reports to the industry principles, itineraries for each traveler, receipts and statements. If you do not type now, it is recommended that you learn. It comes in handy for a lot of things outside your job too.

A recent survey showed that the average agency employs five to six people. The smaller agencies are staffed by generalists who may handle all phases of the agency operation, while larger agencies may have specialists in each field. We have given you a brief idea of what your duties in a travel agency may be. All are important to the operation of an agency, and, therefore, important to you.

Read Section 6 and 7

Answer the following questions and submit for marking:

\section{$\underline{\text { ASS I GNMENT }}$}

Lesson 1

1. Why does a client choose to visit a travel agent rather than arrange his. own travel?

2. What is the main reason why principals offer travel agencies a commission for selling their products?

3. Write a brief outline of the main reasons which gave rise to modern tourism from the 1830's to the 1950's.

4. What position would you like to hold, or what duties 
would you like to perform in a travel agency and why? Be as specific as you can.

PRACTICAL :

Determine by personal survey, by using the Yellow Pages of your local telephone directory, the total number of travel agencies in your neighborhood, town or township.

Note the location of the offices. Are they situated in shopping plazas? Office Buildings? Street level shopfronts on busy thoroughfares?

Based upon your personal observations of local agencies, what is the approximate number of employees in each office? Are the premises attractive and neatly decorated? Are window displays in evidence? Do the exteriors and interiors reflect an orderly, business-like atmosphere?

Based upon your observations, what changes would you make in the matter of office location, layout and general appearance of the premises?

LESSON : TWO

TOPIC: Travel Counselling and Travel Agencies

OBJECTIVES: The student will know the different levels of travel agency operations, the wholesaler, the retailer and their relation to the travel principal. The student will review the role of the counsellor in relation to different types of tourist, and will analyze the job of travel counselling and appreciate the need to be professional. 
REFERENCES: Principles and Procedures of Travel Counselling, Pages 5 to 15 , Sections 8 to 12 .

INSTRUCTOR'S NOTES :

Read Section 8:

Travel agents provide a service to their clients through their travel counsellors. When a client buys a travel product from an agent, the agency is paid a commission by the travel principal. The travel principals are the firms which supply the services such as airlines, railways, hotels and resorts. Thus, the success of an agency depends on the amount of commission it makes from selling products to clients. Most of the commission an agency earns is from selling air fares, therefore, it is necessary for a travel agency to obtain an appointment from the two major airline bodies, IATA and ATC. They specify six criteria to be considered when granting an appointment to an agency. The situation is somewhat different with ship and rail transportation, hotels and tour wholesalers. They do not require an agency to be appointed to sell their products.

Travel is marketed by the following:

1. THE RETAIL AGENT: The travel agent who sells most of his business or "products" directly to the customer or the man in the street.

2. THE TRAVEL WHOLESALER: The agent who puts tours together and sells them to other travel agents. (retailers)

3. THE TRAVEL PRINCIPAL: The firm which supplies the 
service or reservations which the travel agent sells. ie. airlines, hotels, resorts.

Note, however, that in this industry the customer does not receive a product like a box of cereal, which can be returned if not satisfactory. Therefore, the customer will buy the travel product on his assessment of the travel agency, he will consider the reputation of the agency from his dealings with them or stories told by others; he will be influenced by the agency's advertising and promotion, and he is likely to use a travel agent who is easy to reach. Agencies vary in size from small to very large. The size and location of the agency determine the character and qualities needed in its personnel.

Read Section 9:

In lesson one, the reasons why people travel were reviewed. In section 9 we review the different demands made on an agency by the different categories of tourist. Some agencies have become specialized to cater for the special needs of a specific type of tourist.

The trend in travel is for groups of persons to make bulk purchases of transportation and accommodation. This may lead to reduced commission earnings for the agent but the imaginative travel agent can increase sales by using his knowledge of the area to sell extra sightseeing and entertainment to the group. To do this, the agent must have a sound understanding of the reasons why the group tour is 
being undertaken.

Read Section 10:

An analysis of the job of a travel counsellor shows that the skills can be divided into ten main areas. The job description shows the extensive scope of knowledge and duties required to function as a travel counsellor. A travel counsellor is not merely a desk clerk writing up tickets, far from it!

Read Section 11:

Three major trade associations have been formed. This reflects the demand for professionalism in members of the industry, for the protection of the public interest and of the travel industry itself.

Read Section 12:

Answer the following questions:

\section{ASSIGNMENT}

Lesson 2

1. Compile a list of 15 groups, clubs and organizations in your town or district which you think could provide a travel agency with group business. In which tourist category do you think each of the groups would fit? See definitions of types of group travel on pages 8 to 10 in your textbook. 
2. Assume that you are arranging a group tour from Toronto to New York City for a three day weekend holiday for first-time visitors. Specify four components or features you would likely include in such a tour in addition to the trasportation and accommodation.

3. In the job description for travel counsellors produced by the College Affairs Branch of the Ministry of Colleges and Universities, Ontario, a number of abbreviations are used. Give the full name for each, use any source for information.
a) C.A.T.M.
b) O.A.G.
c) O.H.R.G.
d) T.I.M.
e) I.A.T.A.
f) A.T.C.
g) M.C.O.
h) A.T.O.
i) A.B.C.
j) I.T.C.
k) C.I.T.C.
1) A.S.T.A.
m) O.T.I.C.
n) C.T.C.
o) C.B.I.T.

PRACTICAL:

Practical assignements are given in order that the 
student can obtain exposure to knowledge available to the intdrested student. Proof of completion of the practical assignments should be completed. However, marks are not allocated to practical assignments and the submission of lesson assignments should not be delayed if practical assignments are not completed.

1. Select three foreign tourist, airline or shipping offices and visit them if possible. Find out the range of information they handle and services they provide. Obtain their tourist literature and familiarize yourself with the contents.

2. Read copies of the leading Canadian travel journals, magazines and newspapers. Study the news content and the editorials to become familiar with the current issues and problems in the trade. Also, study the advertisements to develop awareness of new products which the retail agent can offer for sale. Specify four current issues in the Canadian travel industry giving brief backgrounds on each.

\section{LESSON : Three}

TOPIC: $\quad$ Travel Documents

OBJECTIVES: The student will have a thorough knowledge of the requirements for passports, visas, tourist cards and international health documents; the student will know why it is important to be accurate when handling travel documents.

REFERENCES: Principles and Procedures of Travel Counselling Pages 14 to 19 , Section 13 to 15 
INSTRUCTOR'S NOTES:

Read the introductory paragraph on travel documents. Read Section 13:

Take careful note that it is the responsibility of the travel counsellor to inform his client of those specific documents which must be obtained to visit or pass through countries en route to the destination and to re-enter Canada.

Every travel counsellor must be thoroughly familiar with the requirements and must know what reference manuals to consult in the event of having to handle a unique problem. A visitor's trip can be completely ruined if his travel counsellor has been inaccurate with his advice in any of these areas. This will result in harmful remarks being made about the travel agency and subsequent loss of business.

The student is urged very strongly to spend as long as is necessary to understand all the requirements thoroughly. If, on first reading the sections of this lesson, and area is not clear, re-read until it is understood. Make brief, careful notes of the specific requirements, limitations and distinctions of each document. Consult your notes from time to time as the course progresses to refresh your memory. Study the Application for Passport. Form "A" provided with this lesson.

Read Section 14:

Here too, the student is urged to become thoroughly 
familiar with the differences between a passport, a visa and a tourist card.

Study the form on page 17: Application for a Mexican Tourist Card.

Read Section 15:

Remember that the health regulations are subject to change and the travel counsellor must always be informed of the most recent regulations. Some of the regulations laid down apply even where the visitor is only in transit, and some of the regulations laid down are for re-entry to Canada at the end of the overseas trip.

Study the form on page 16: International Certificate of Vaccination, Smallpox.

\section{ASSIGNMENT}

Lesson 3

1. State Clearly the differences between:
a) a passport
b) a tourist visa
c) a business visa
d) a transit visa
e) a tourist card

2. Who are the issuing authorities for:
a) passports
b) tourist cards
C) visas 
3. a) Name the three diseases with which the health requirements are mostly concerned.

b) Name the specific document in which vaccinations must be recorded for travel purposes.

c) What is the cost for this document?

d) Specify three things which must be done by the client before this document becomes valid.

4. Complete the enclosed application for a Canadian passport as if you were applying for a passport for yourself. This should be either typed or printed in block letters using blue or black ink. Take care to study the general information and the instructions thoroughly before you begin, these are printed on both sides of the application. (Figure 2)

5. Complete the attached application for a Mexican Tourist Card on behalf of yourself. (Figure 3)

LESSON : $\quad$ Four

TOPIC: $\quad$ Controls and Reference Manuals

OBJECTIVES: The student will appreciate the need for customs restrictions and know the role of the Customs Department as it affects the traveler; the student will be familiar with major tourist currencies and be aware of foreign exchange and currency restrictions; the student will obtain and use basic reference materials used in travel 


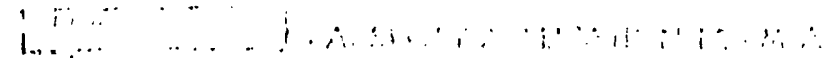

i.

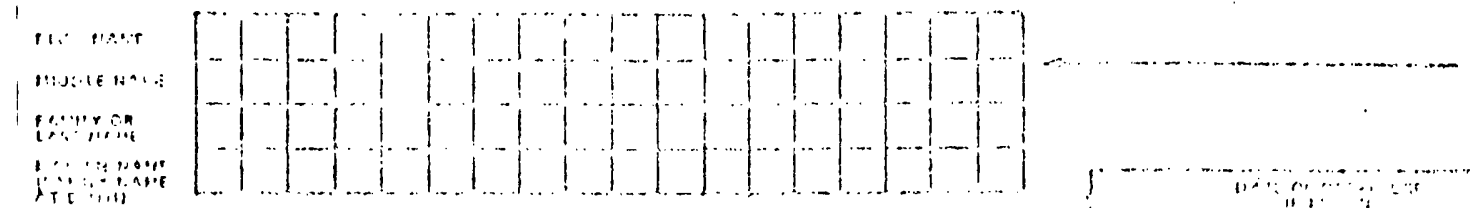
(ston

2.

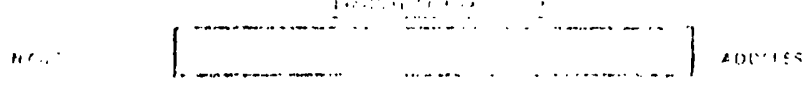

$\ln , 2=4: 3$

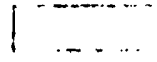

r.

$\because$

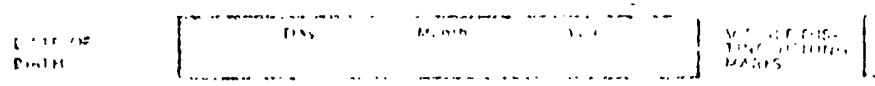

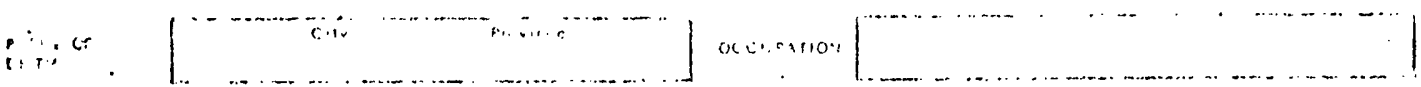

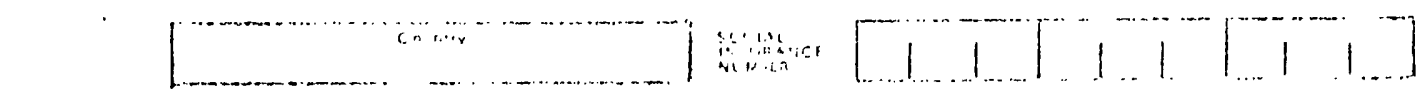

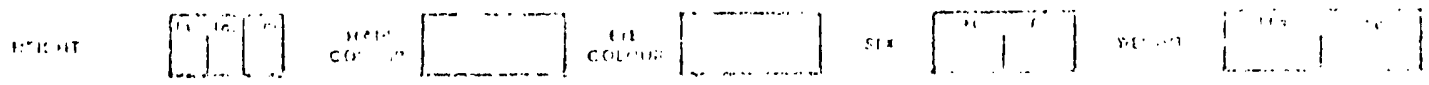

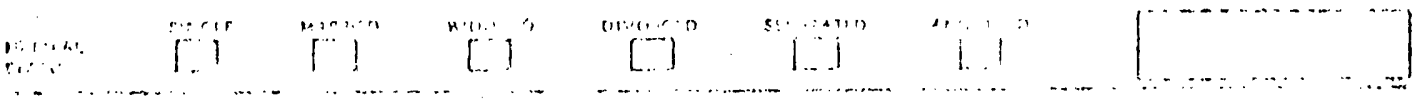

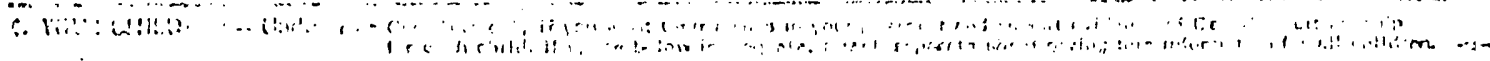

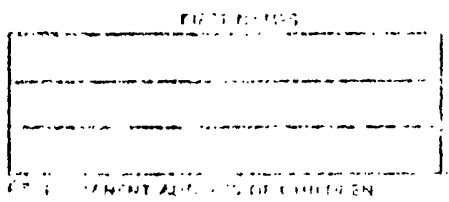

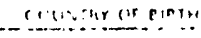
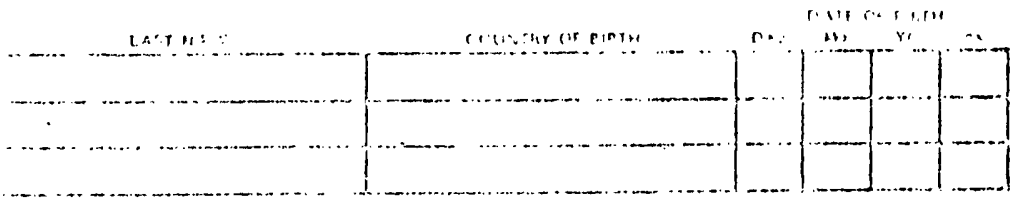

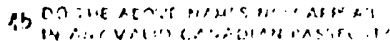

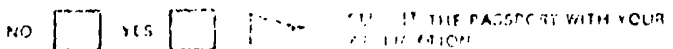

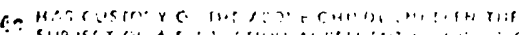

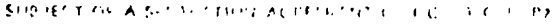

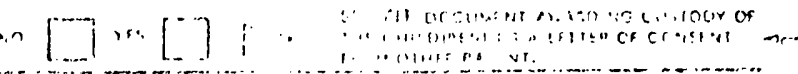

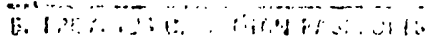

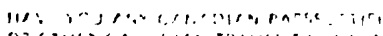

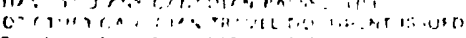

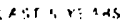

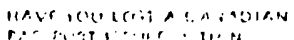

ri.

il. $1+1+1, \ldots$,

ins $\sin (1$,

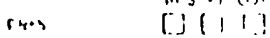

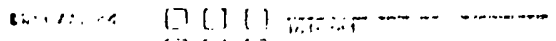

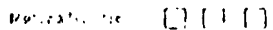

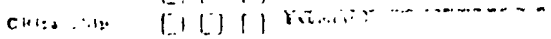

n:m :- [j] [ ?

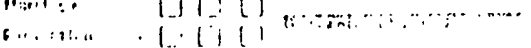

lles: $\quad$ ।

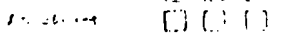

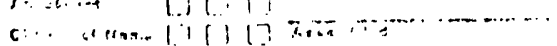

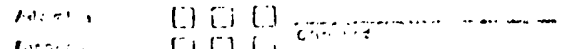

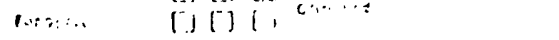

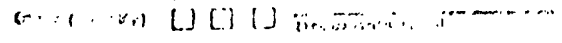

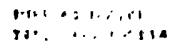




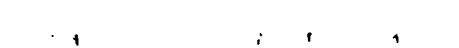

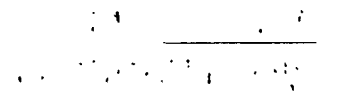

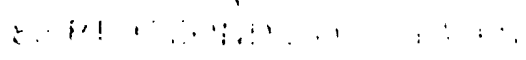

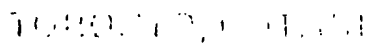

$$
\begin{aligned}
& \text { I.: : : : : : } 1 \\
& 1 \therefore \text { in }
\end{aligned}
$$

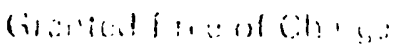

i.tasidinitit.

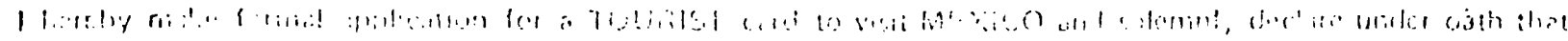

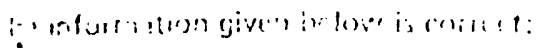

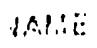

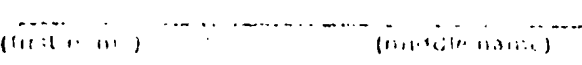
: ,

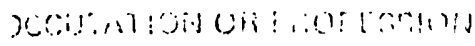
Li:C: ri: Eli:TH HILki?

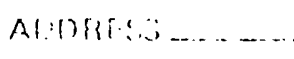

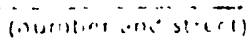

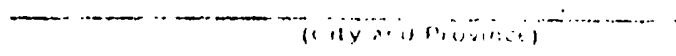

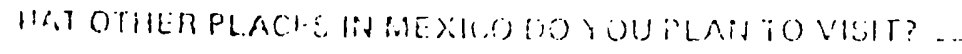

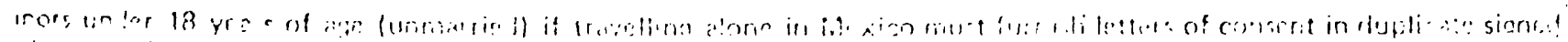

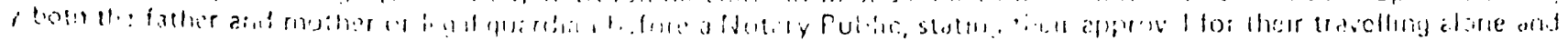
*

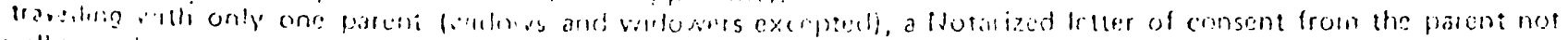

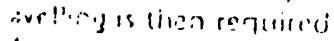

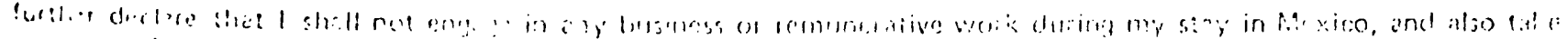

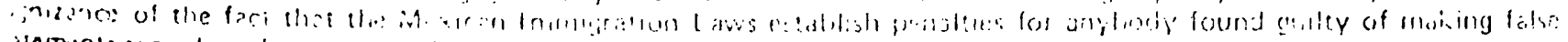

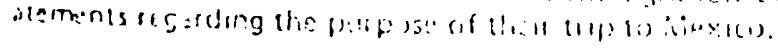

Sisminiur .....

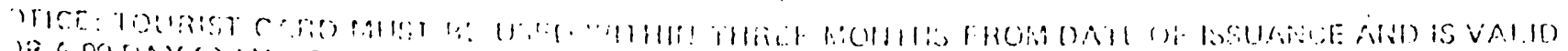

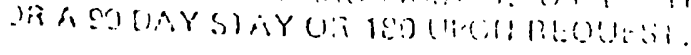

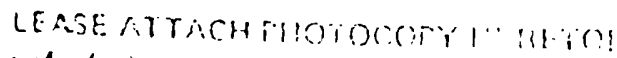

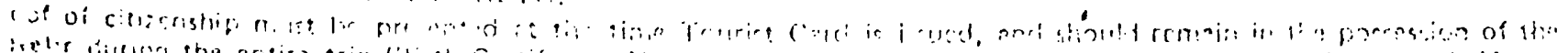

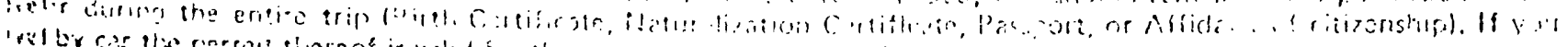

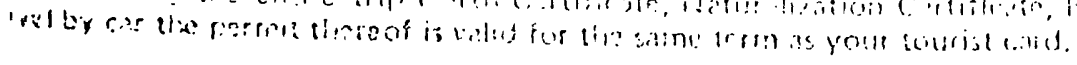

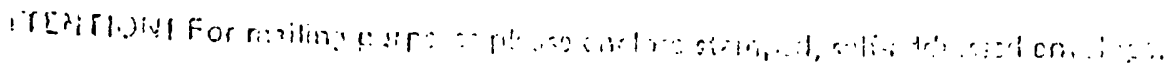


counselling, including the TIM, Travel Abroad, and Canadian Government publications.

REFERENCES: Principles and Procedures of Travel Counselling Pages 21 to 23 , Sections 16 to 18. TIM Manual.

INSTRUCTOR'S NOTES :

Read Section 16:

There are as many variants to the Customs restrictions placed on travelers as there are countries and it is unlikely that a person could know all of them from memory. However, certain items are continually mentioned, in particular: alchohol, in which wine is often considered separately from spirits such as rum and whiskey, tobacco and/or cigarettes and perfume. Currencies will be considered in section 17 .

The two other areas which are almost universally banned are the importation of drugs other than those medically prescribed, arms, ammunition and weapons in general.

Where the traveler intends to go hunting he may be required to obtain a permit under the local laws. It is worth remembering that these restrictions have been introduced often in response to abuses or threats of damage to the fauna of the country involved, such as the wildlife of East Africa. The travel counsellor must impress upon his client the fact that hostility will arise if he should attempt to flout local laws. He must, therefore, abide by the laws of the host country at all times.

The manner of making customs declarations also vary extensively. Sometimes the traveler is asked to choose between a gate saying "Nothing to Declare" and another one 
for "Customs Declaration", while at the other extreme in some countries every piece of luggage is checked. Persons entering Canada and returning residents may make a written declaration which in turn will determine the extent to which Customs officials will check the luggage.

Study the document illustrated on page 20, Customs Declaration Form for returning Canadian residents. (Figure 4)

Read Section 17:

Many countries, such as those of Eastern Europe, place restrictions on money taken into the country and local currency taken out, and there are very severe penalties for persons who break the regulations.

No attempt should be made to memorize all the restrictions on importation or the rate of exchange between Canadian and foreign currencies. Currency exchange rates change almost daily and the current rates are available from banks and foreign exchange houses such as Deak Canada Ltd.

The student should, however, familiarize himself with the names of the major tourist currencies:

$\begin{array}{lll}\text { Country } & \text { Currency } & \text { Code } \\ \text { Australia } & \text { Australian Dollar } & \text { AUD } \\ \text { Austria } & \text { Schilling } & \text { AUS } \\ \text { Barbados } & \text { Barbados Dollar } & \text { BAD } \\ \text { Bahamas } & \text { Bahamas Dollar } & \text { BMD } \\ \text { Belgium } & \text { Belgian Franc } & \text { BFR } \\ \text { Bermuda } & \text { Bermuda Dollar } & \text { BED }\end{array}$


Figure 4

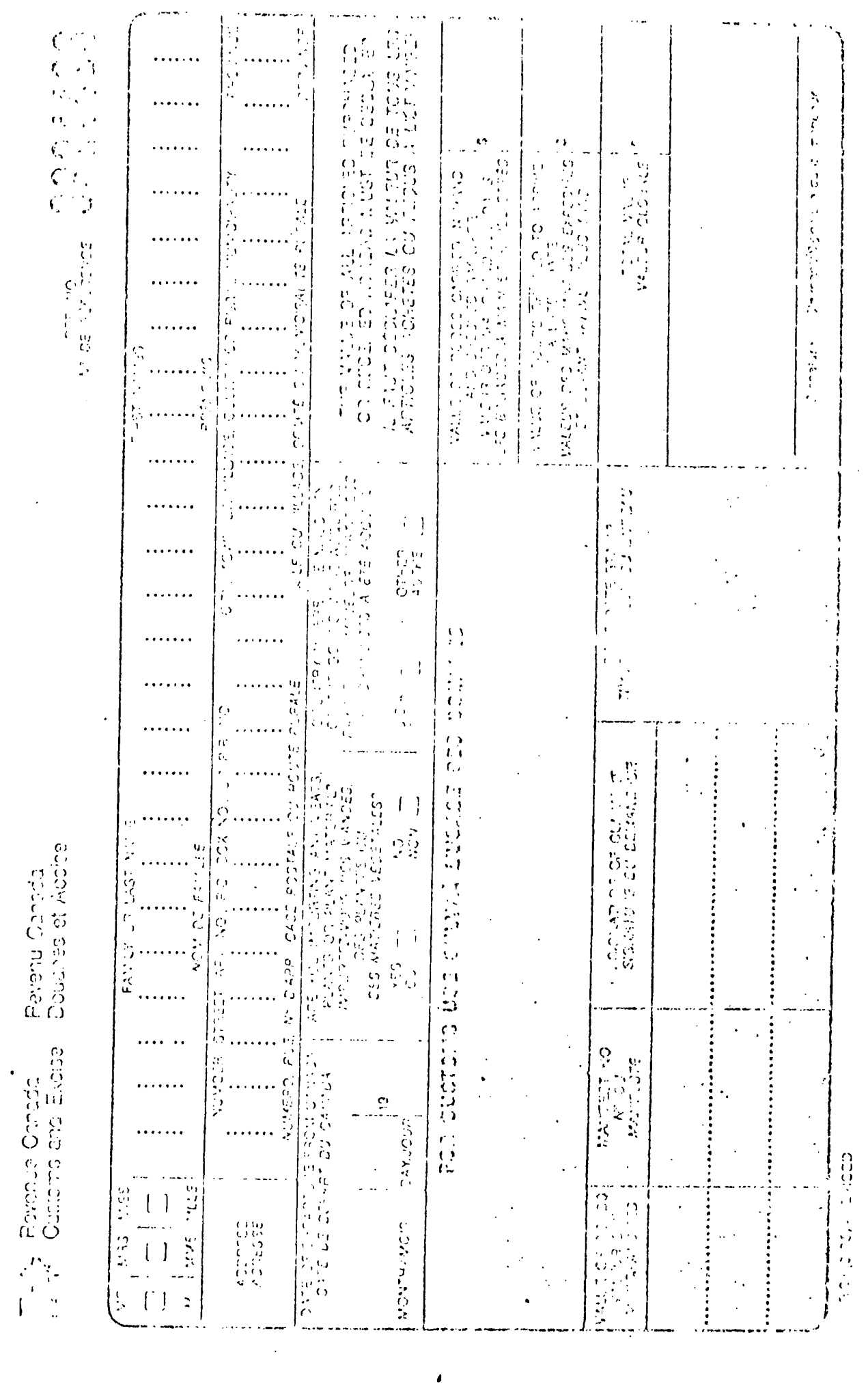

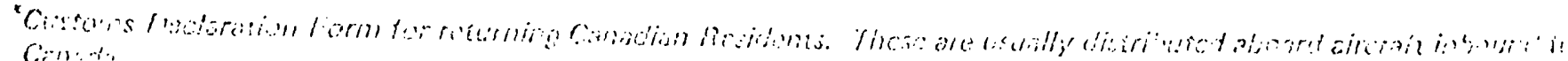




\begin{tabular}{|c|c|c|c|}
\hline Country & Currency & & Code \\
\hline Denmark & Krone & DKR & DKR \\
\hline England & Pound sterling & & UKL \\
\hline France & Franc & & FFR \\
\hline West Germany & Deutsche Mark & & DMK \\
\hline Greece & Drachma & & DRA \\
\hline Israel & Israeli Pound & & ISL \\
\hline Italy & Lira & & LIT \\
\hline Japan & Yen & & JYE \\
\hline Mexico & Peso & & MEP \\
\hline Holland & Guilder & & DFL \\
\hline Norway & Krone & & NKR \\
\hline Portugal & Excudo & & ESP \\
\hline Spain & Peseta & & PTS \\
\hline Sweden & Kroma & & SKR \\
\hline Switzerland & Swiss Franc & & SFR \\
\hline Turkey & Lira & & TUL \\
\hline Yugoslavia & Dinar & & YUD \\
\hline
\end{tabular}

Read Section 18:

It is impossible to know and remember everything, especially information which is continually changing, such as currency exchange, and customs restrictions. However, a good travel counsellor will know where to look to find information and who to ask about it.

Obtain your own copies of the Canadian Government Publications mentioned in this section. TIM, Travel 
Information Manual is a very important basic working manual. Study the instructions printed on page 22 or your textbook, then proceed to answer the questions using the TIM Manual provided.

\section{ASS IGNMENT}

Lesson 4

1. From the list of currencies given:

a) State the names of countries whose unit of currency is called the pound.

b) State the names of countries whose unit of currency is called the krone.

c) State the names of countries whose unit of currency is called the franc.

d) What are the units of currency used in:

Japan
Greece
Mexico
Barbados
England
Switzerland
Italy
France
Holland
Bahamas

2. Specify the documents required to held by a Canadian tourist visiting Holland. (Netherlands) 
3. Specify the documents, including any health certificates, which are required to be held by an American Citizen visiting Kenya.

4. State the entry requirements for Jamaica for the holder of a Greek Passport.

5. How many cigarettes may a visitor from Canada bring with him through Japanese Customs? How many cigarettes may an American citizen import into Japan?

6. Is there a tax charged passengers upon departure from the Republic of Korea? If so, how much?

7. What items can a resident of Mexico import free of duty when visiting Finland?

8. Specify the currency restrictions which apply to visitors of any nationality to the U.S.S.R. (Russia).

9. A Canadian citizen arrives at Bucharest Airport in Romania at 0900 hours, his connecting flight from Bucharest to Moscow is scheduled to leave at 0700 hours the next day. Is he required to obtain a Romanian visa if he remains at Bucharest Airport?

\section{PRACTICAL :}

1. Read the "Admission and Transit Restrictions" applicable for Uganda and for India.

2. Note carefully the strict requirements under Visas "Additional Information" for China (People's Republic). 


\section{LESSON : $\quad$ Five}

TOPIC: $\quad$ Travel Insurance

OBJECTIVES: The student will have a basic knowledge of the types of travel insurances available to travelers; the student will appreciate the need to make the traveler aware that insurance is available: the student will compute simple insurance requirements.

REFERENCES: Principles and Procedures of Travel Counselling Pages 24 to 27 , Sections 19 to 27 .

INSTRUCTOR'S NOTES :

Read Introduction to Travel Insurance

Most travel agencies sell travel insurance. It is an extra service which agents can provide to the traveler and also allows them to earn additional revenue. A client cannot be forced to purchase insurance coverage but should be advised of the benefits and protection travel insurance provides.

Read Section 19:

Several low cost charter transportation arrangements usually carry stiff penalties such as loss in part or in full of the cost of the ticket in the event of the client cancelling - whatever the reason. The travel counsellor must, in fairness to the client, point out these penalties and should advise him about the type of insurance available to protect him from losses through cancellation.

Study fully the example on page 25 - Trip Cancellation 
Insurance. The premium rates under this scheme mean simply that a traveler whose travel costs amount to $\frac{50}{}$ can insure himself against loss if he cancels by paying $\$ 1.50$ premium. At the other end of the scale, travel plans costing $\$ 2,000$ can be protected by a premium of $\$ 60$. Note claim procedures shown on page 26 .

Read Section 20:

Another major worry for travelers is loss of baggage. This could sever hardships on the journey. Study the example on page 26 - Worldwide all risks baggage and personal effects insurance. This chart shows protection offered for specified periods (from 3 days to 180 days) and to the value of between $(\$ 200$ to $\$ 3,000)$. Clients should be made aware of the importance of insuring their baggage for its full replacement value. Note too, the all-inclusive nature of this baggage insurance, example, providing coverage of the insured's personal effects; note exclusions.

Read the remaining sections 21 to 27 .

\section{ASSIGNMENT 5 \\ Lesson 5}

1. Using the chart on page 25, calculate the rate to be paid by a 71 year old person who wishes to obtain insurance against trip cancellation. His transportation costs amount to $\$ 1,250$. 
2. Using the charts on page 25 and 26 , calculate the rate to be paid by a 35 year old traveler wishing to insure against trip cancellation for a 60 day voyage costing $\$ 3,050$. In addition, he/she has asked for your advice about insuring his/her baggage and personal effects which he/she estimates will be have a value of $\$ 2,000$. Assuming that he/she will be on the move for most of his/her voyage, how would you advise him/her on this? If he agrees to insure, what will it cost him/her?

LESSON : . Six

TOPIC: $\quad$ Legal Responsibilities

OBJECTIVES: To make the student aware of the law as it relates to travel agents and action taken by dissatisfied clients.

REFERENCES: Principles and Procedures of Travel Counselling Pages 27 to 30 , Sections 28 and 29 .

INSTRUCTOR'S NOTES :

Read sections 28 and 29 and the Air Traffic Conference Sales Agreement on page 29 and 30 .

Read Introductory paragraph to Legal Responsibilities:

The Travel Industry Act of 1974 was passed by the Government of Ontario. The objective of the legislation was to regulate the travel industry to provide protection for the consumer. This was done by passing legislation which requires every travel agency and wholesale tour operator doing business in ontario to be duly registered.

The Ontario Travel Industry Act is administered and 

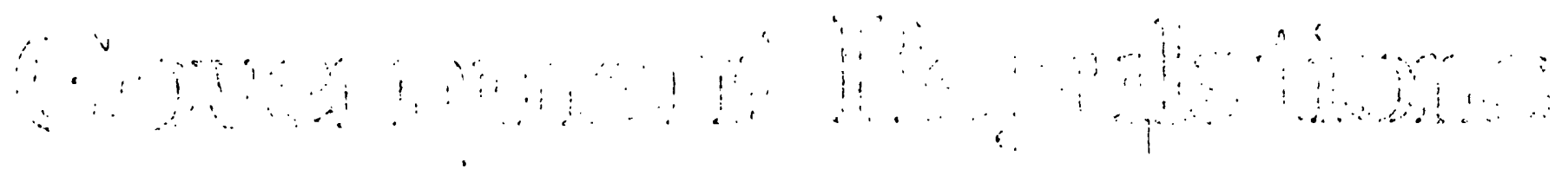

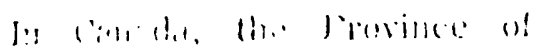

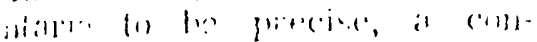

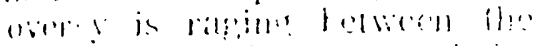

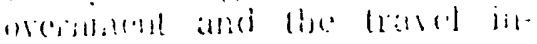
Mrs.

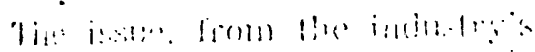

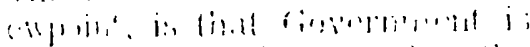

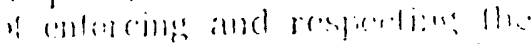

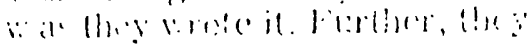

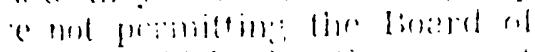

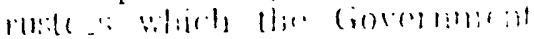

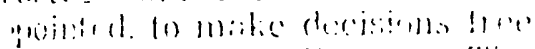

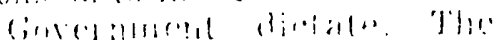

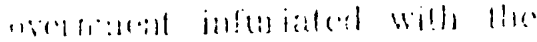

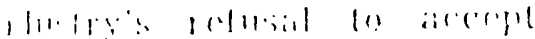

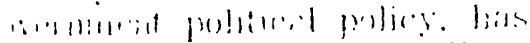

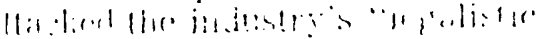

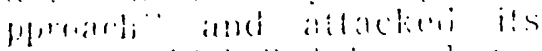

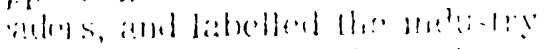

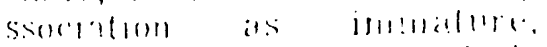

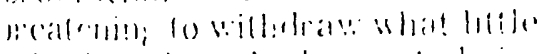

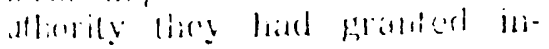
astsy.

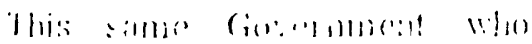

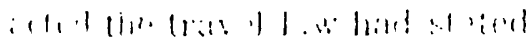

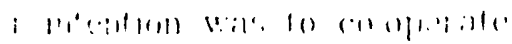

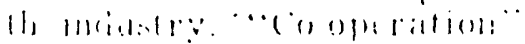

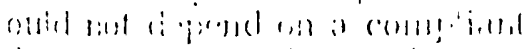
lablry llat! whe?: hill al

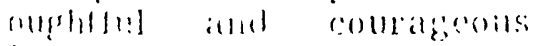

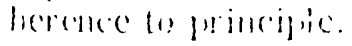

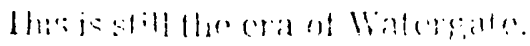

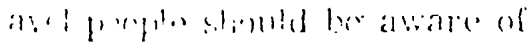

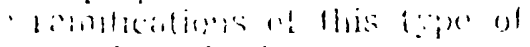

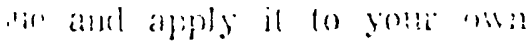
aris.

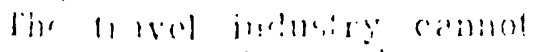

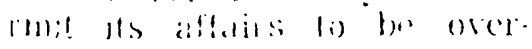

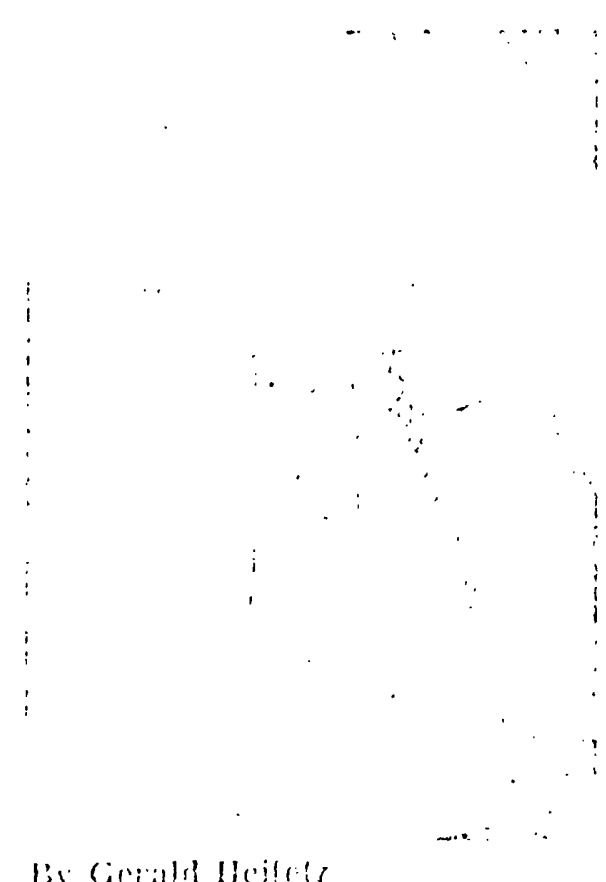

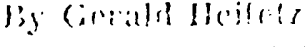

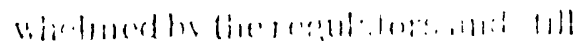

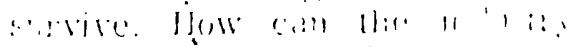

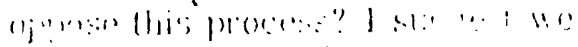

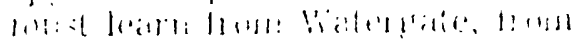

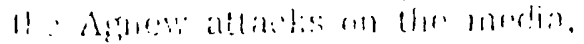

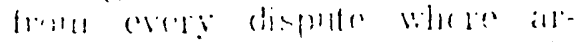

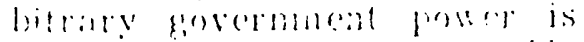

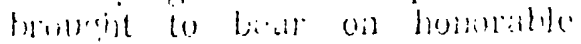
[xille.

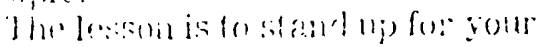

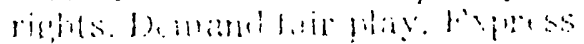

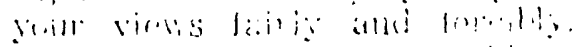

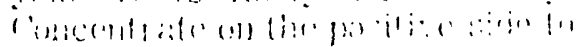

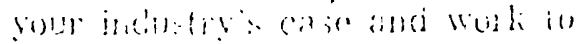
cille the defictereders.

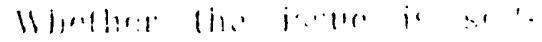

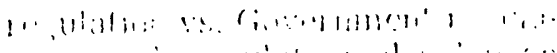

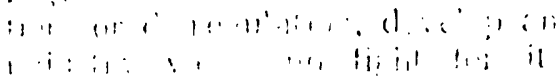

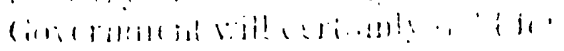
$\therefore$ lis $\because \because 3$

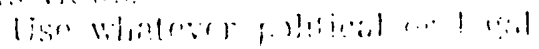

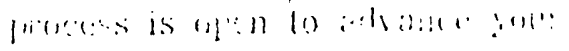
(a.)."

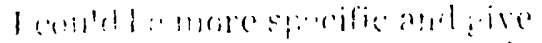

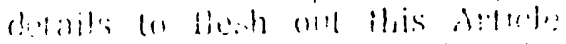

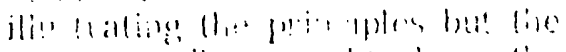

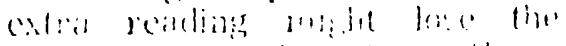

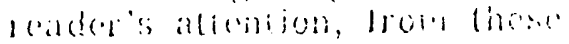
hatlomerl matabiome:

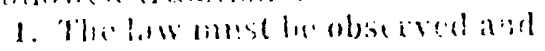
mise'is.

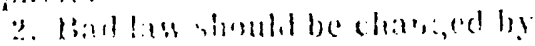

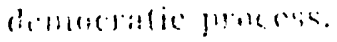

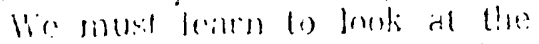

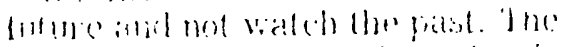
fored industy wo live in

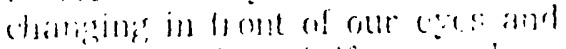

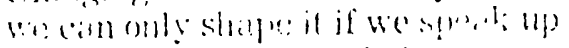

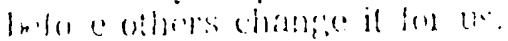

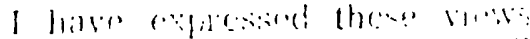

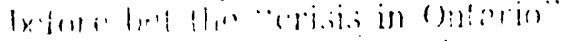

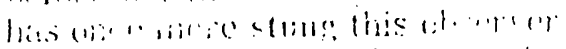

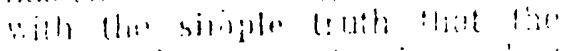

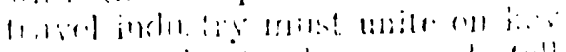

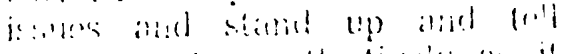

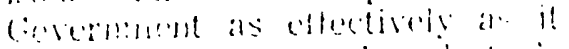

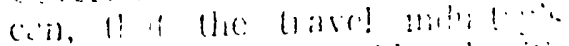

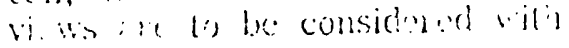
re. inele

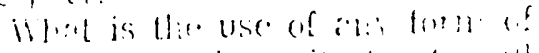

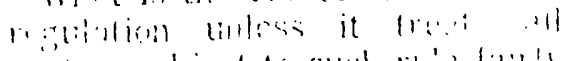

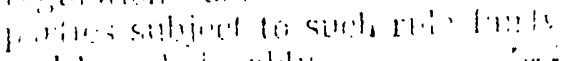

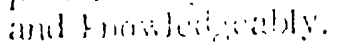


The Ministry of Consumer \& Commercial Relations Business Practices Division

Central Registration

55 Yonge street

Toronto, Ontario

M7A $2 \mathrm{H} 6$

\section{ASSIGNMENT}

Lesson 6

1. State three instances where a travel agency could be held liable by a client for negligence.

2. State three instances or examples where a travel agency could be held liable by a client for breach of contract.

3. The textbook mentions two instances when a travel agency might be held liable for the acts of "third party" suppliers. Suggest two additional instances.

4. The Air Traffic Conference (ATC) Sales Agency Agreement (portion on pages 29 and 30) specifies a number of duties and responsibilities which the Agent is expected to carry out for the purpose of promoting and selling passenger air transportation on behalf of the Carrier. State five of these duties the Agent is required to observe.

PARACTICAL :

Contact the Ministry requesting detailed information necessary to register a retail travel agency which is conducting business in the Province of ontario. 
For students residing in Provinces other than Ontario, contact the Provincial Department or Ministry which is likely to regulate travel agencies to ascertain the current state of legislation in this area.

LESSON : Seven

TOPIC: $\quad$ Professional Ethics and Standards

OBJECTIVES: The student will know the role of members of REFERENCES: Principles and Procedures of Travel Counselling - Pages 28, 31 and 32, Sections 30 to 33 .

INSTRUCTOR!S NOTES :

Read the introductory paragraph, Professional Ethics and Standards .

To earn the respect and confidence of the public, every profession must conduct its affairs in an exemplary manner. This requirement is even greater in an area such as the travel industry which is in fact a service to the public. Every member of the industry has a duty to donduct their affairs in such a manner that the entire profession will gain in stature. If one travel counsellor indulges in unfair practice it will reflect badly on all travel counsellors.

Read Section 30:

ASTA, the American Society of Travel Agents, has drawn up a code of conductand ethics which has universal application. The guidelines are self-explanatory. In Relations with Other 
Travel Agencies they spell out the lesson of dealing with others as you would like them to deal with you.

Read Section 31:

The points made here cannot be too strongly stressed. A client, the would be traveler, comes to his counsellor for guidance. The counsellor is in a position of strength and can take advantage of his client's lack of knowledge, but the traveler will soon discover the "rip off" and his trust in that travel counsellor will be damaged irreparably, sometimes even if it was a genuine error.

Read Section 32:

If a customer takes the trouble to make a complaint to you it means that he was genuinely annoyed. So do something. Listen to him. Sympathize with him. Try to be understanding and before long he will be sufficiently pacified, proving his annoyance was not so great that it ruined his trip.

Should you wish to, follow up on cases where you think a significant breach has occurred, with the aim of preventing a recurrence with you future clients. In case your client is being very aggressive and insisting on taking action against you, he may be somewhat pacified if you let him know what you plan to do to get satisfaction and to prevent similàr events from happening again. Make it clear that there was no collusion between yourself and the third party. 
Read Section 33:

Remember that in some cases there are insurances to cover cancellations and recover monies which would otherwise be lost. This reinforces the desirability on informing clients about cancellation insurance.

\section{ASSIGNMENT}

Lesson 7

1. Discuss the implications of the following guidelines for professional conduct:

a) advising clients in writing about requirements such as charges in the event of a booking having to be cancelled or changed.

b) commissions paid by any carrier may not be divided with any individual not employed by the same company.

c) the business practices of competiters must not be disparaged.

2. Explain what you would do to pacify a client who has just returned from London, England, and has complained bitterly that his confirmed hotel rservation was not honoured. Upon checking his booking record you determined that:

a) the hotel confirmed the reservation to you in writing.

b) A deposit for the accommodation was paid by the client and remitted by you to the hotel, and

c) the hotel has acknowledged receipt of the deposit. 
TOPIC: Office Procedures

OBJECTIVES: The student will know basic office procedures used in travel agencies and will acquire skills in: filing documents, selecting materials for filing, accounting procedures and calculations, handling refunds, and good clerical practices. REFERENCES: Principles and Procedures of Travel Counselling Pages 32 to 34 , sections 34 to 36 .

INSTRUCTOR'S NOTES:

Read SEction 34 :

Information which cannot be found when it is needed is of no use. This requires a discriminating appreciation of the large volume of useful and useless information which can pile up very quickly in an office. Then, having selected the information you will keep, you need to store it in such a manner that you can quickly locate it when you need to use it. Bear in mind also that you need not keep information which is only rarely used, provided that there is another source where you can get the facts quickly as needed.

Rèmember too that information to be filed must be done at the first opportunity, ideally, return to file immediately after use. When material is allowed to lie loose outside their files they invariably get misplaced or lost, and this causes time waste when it is needed later.

The agency will already have established its filing system, and chosen the categories of information it intends 
to keep in file. It is of crucial importance that everyone who uses the filing cabinets stick to the system. Something as simple as alphabetical filing can go wrong with names like McGregor and MacGregor, unless everyone knows how to handle such complications.

Apart from alphabetical filing, information may be filed chronologically or numerically. It all depends on which system makes for easier location of the information.

Not all information is siited for filing, or storage in filing cabinets. This suits loose sheets of paper and cards. Books and manuals are stored on shelves and brochures are displayed on racks. Where the volume of material to be filed is bulky, it is possible to use visual aids to assist in locating material, e.g. by colour coding.

Read Section 35:

In this section a brief description of accounting procedure for the sale of commissionable services is geven. Read it carefully and make sure that you grasp the basic steps. You need to understand how the work of other employees, such as the bookkeeper, fit in with yours. An understanding of what they do will help you to avoid making errors which affect the work of the other staff.

Notice that commission due to the travel agent is paid by a simple deduction from the amount received from the client's payment. This does not mean the client has paid the travel agent commission, it is merely a simple way to collect 
the commission rather than billing the hotel or other travel principal.

Read Section 36:

No further explanations are necessary. However, it should be mentioned that efforts should be made to interest the client in some future travel so that you keep the client although you have lost the present booking.

Additional Notes:

In general you need to develop the ability to write and print legibly. Remember that your travel documents are to be read by persons perhaps thousands of miles away from your location. They cannot call and ask what you have written!

Typewriting skill is relatively easy to acquire, and is very important to possess where correspondence, itineraries, reports have to be handled. There are standard formats of letter layout, learn one and use it.

\section{ASSIGNMENT}

Lesson 8

1. Assume that you have been given the responsiblity of of setting up a filing system in a brand new travel agency. Describe how you would establish filing systems for:
a) Tour brochures
b) Cruise brochres and deck plans
c) Booklets, brochures and clippings giving information 
on various holiday destinations

d) Passengers booking (reservations) records.

Be a specifice in your answers as possible.

2. Calculate the following transactions:

a) 7 nights accommodation at $\$ 25$. Service Charge $10 \%$

Tax 5\%. A $12 \%$ commission is earned on accommodation.

i How much does the hotel receive in dollars?

ii How much does the client pay in dollars?

iii How much does the qravel agent receive in dollars? Presentation and layout of information is important. A calculator would be used in a travel agency.

b) 3 nights accommodation a $\$ 15.4$ nights at $\$ 20$. Service charge $5 \%$ Tax $2 \%$ A $10 \%$ commission earned on accommodation.

i How much does the client pay for accommodation in dollars?

ii How much does the client pay for service charge in dollars?

iii How much does the client pay for taxes in dollars?

vi How much does the travel agent receive as commission in dollars?

\section{$\underline{\text { Refunds }}$}

3. In the first transaction a) above, a 25\% late cancellation fee was charged by the hotel. How much was refunded? In the second transaction b) above, cancellation notice was given 12 days before arrival at the hotel. Ten days notice was required or a $15 \%$ fee would be payable. How 
much was refunded?

Using the Hotel Edison Tariff shown on page 227 of your textbook, determine travel agents commission earned on the following :

-minimum rate single room, arrival December 12 , check out December 15 .

LESSON: Nine

TOPIC: $\quad$ World Geography

OBJECTIVES:' The student will know the importance of being familiar with the travel poduct and will begin to build up knowledge of tourist destinations; the student will read and study maps and atlases and will locate major tourist destinations; the student will use the 24 hour clock. REFERENCES; Principles and Procedures of Travel Counselling Page 237, Introduction and Section 1

National Geographic Atlas of the World or other reputable atlas.

Travel guides by reputable authors such as Fodor, Fielding, Michelin, Nagel.

INSTRUCTOR'S NOTES :

Read the introduction to Tourist Destinations:

The important point to note is that tourist geography cannot be taught but can be learned. Knowledge of tourist destinations is built up over a period of time. It is an 
on-going process subject to change since conditions are changing daily throughout the world.

Initially the student will concentrate on reading maps and atlases so that names of places, cities, towns and natural features all over the world become very familiar. A simple aid to remembering is by identifying places through their relative location to other places.

Take special care to be accurate. Sometimes there are two or more places with names similar enough to be confusing, the capital of Jamaica is Kingston while the capital of another Caribbean island, st. Vincent, is Kingstown. In south and central America, many different countries have cities with similar names. There is a Panama City in Florida as well as in the Republic of Panama. Grenada is an island in the Caribbean Sea as well as a city in the south of spain. An awareness of place names and their correct spelling important when working out flight itineraries. When using Eurpoean railway schedules it is important to be aware of differences in the naming of some cities and towns; e.g. Vienna = Wien; Florence $=$ Firenze; and Brussels = Bruxelles .

Locate an atlas which has details of climate, rainfall and temperatures. Study the climatic zones and be aware that the four seasons are not a universal phenomenon. Countries in the tropics do not experience the same changes of climate that we in Canada do, there is no snow except in high mountain regions which you can discover from your maps. In the tropics there is sun all year round, with the seasonal changes being periods of greater or lesser rainfall. 
Lesson 9

1. On the attached map of Aftica, indicate in red the countries where English would be most likely understood and in blue where French would most likely be understood.

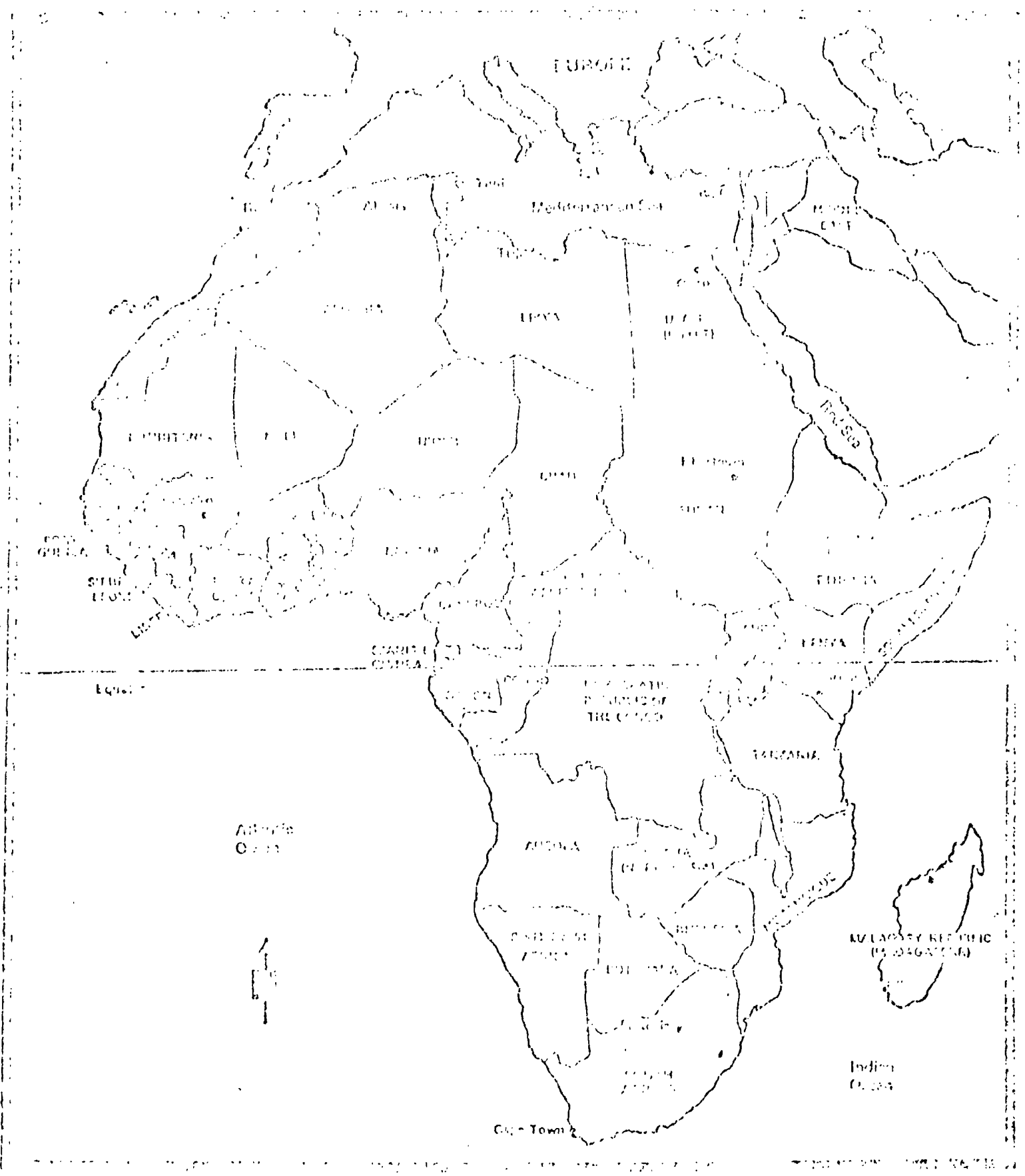

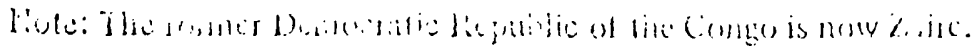


2. Here is a list of 50 popular tourist destinations. For each one given, state their location, state their climatic zone and locate each one on the attached maps.

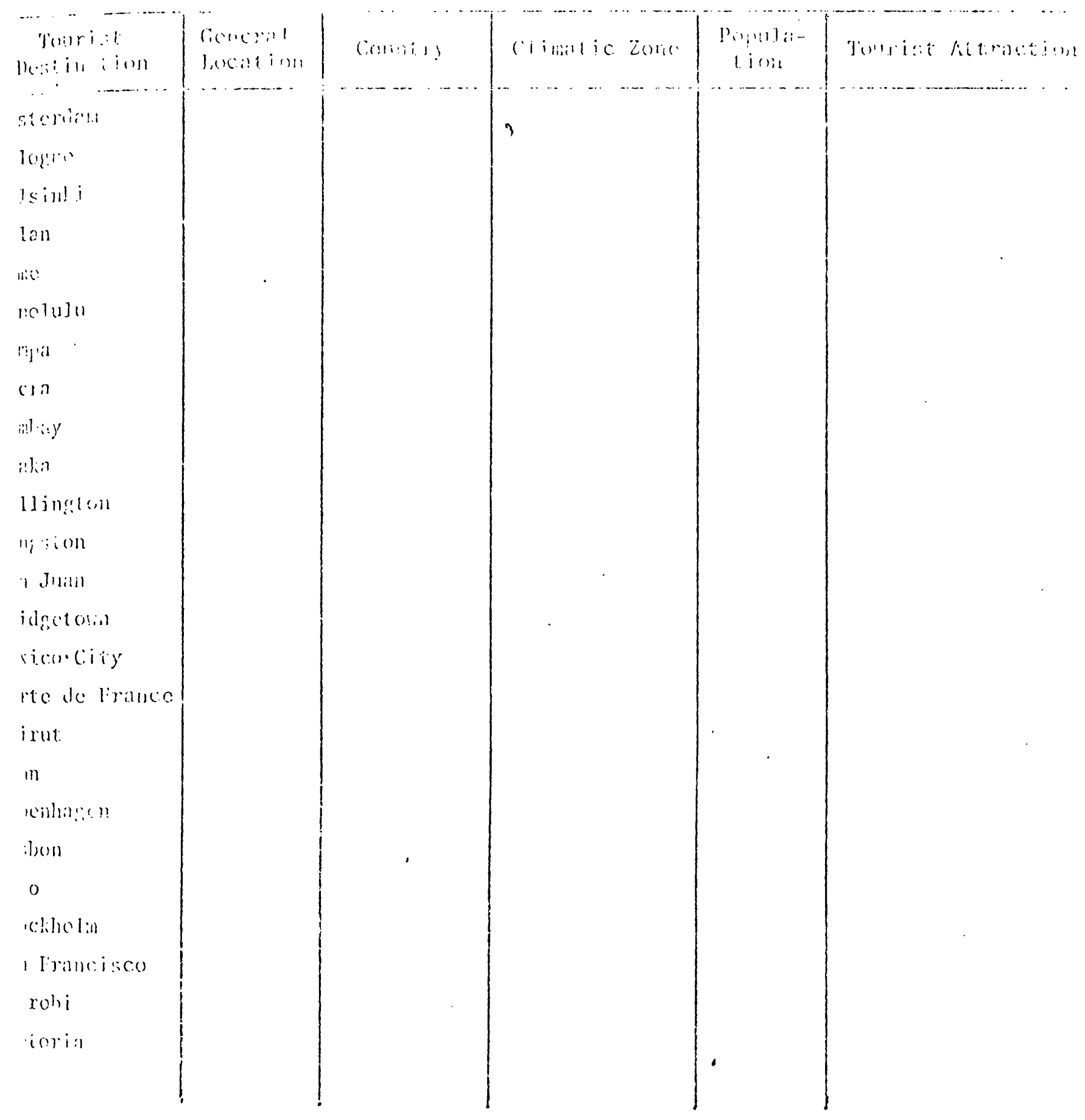




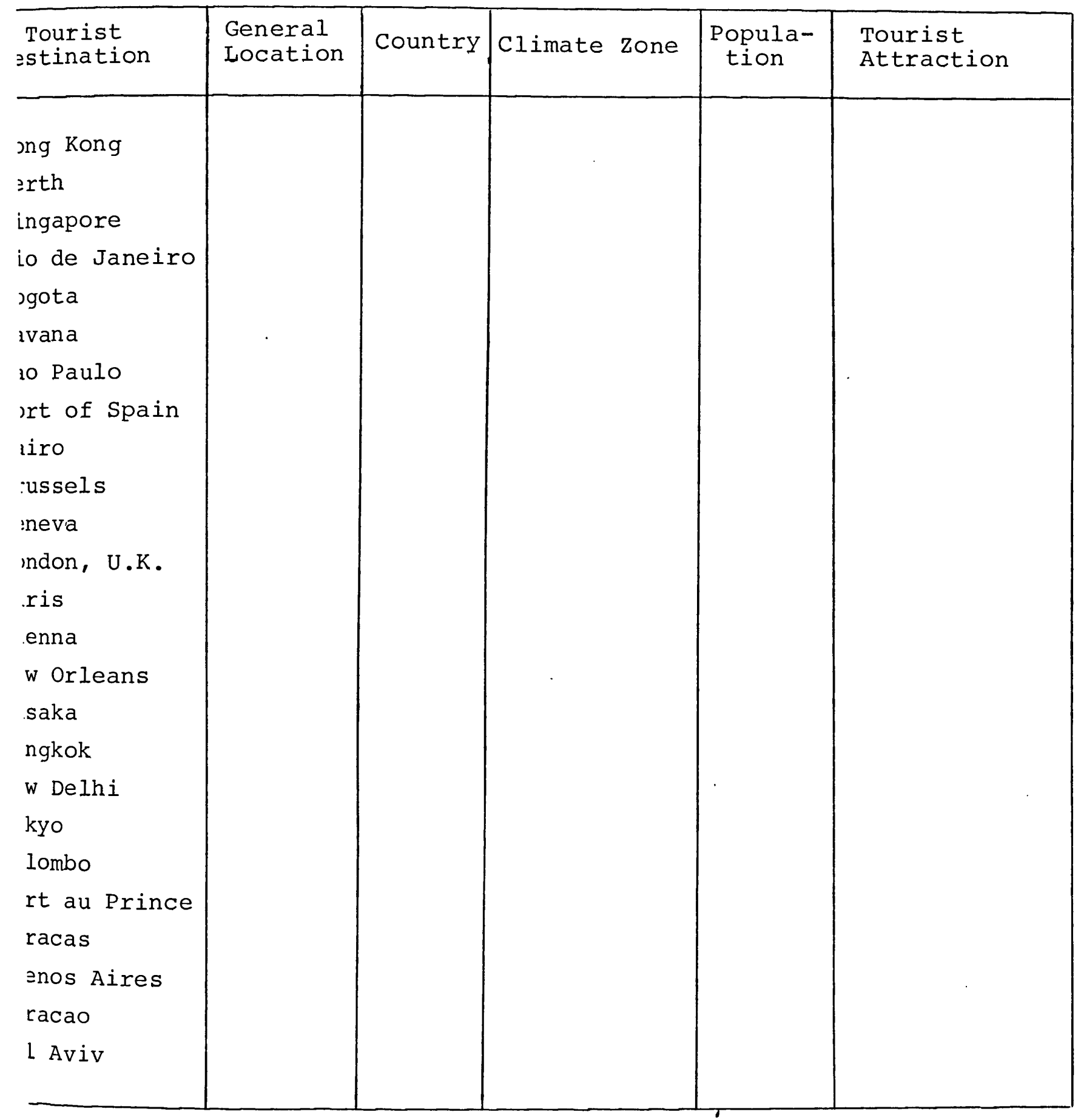




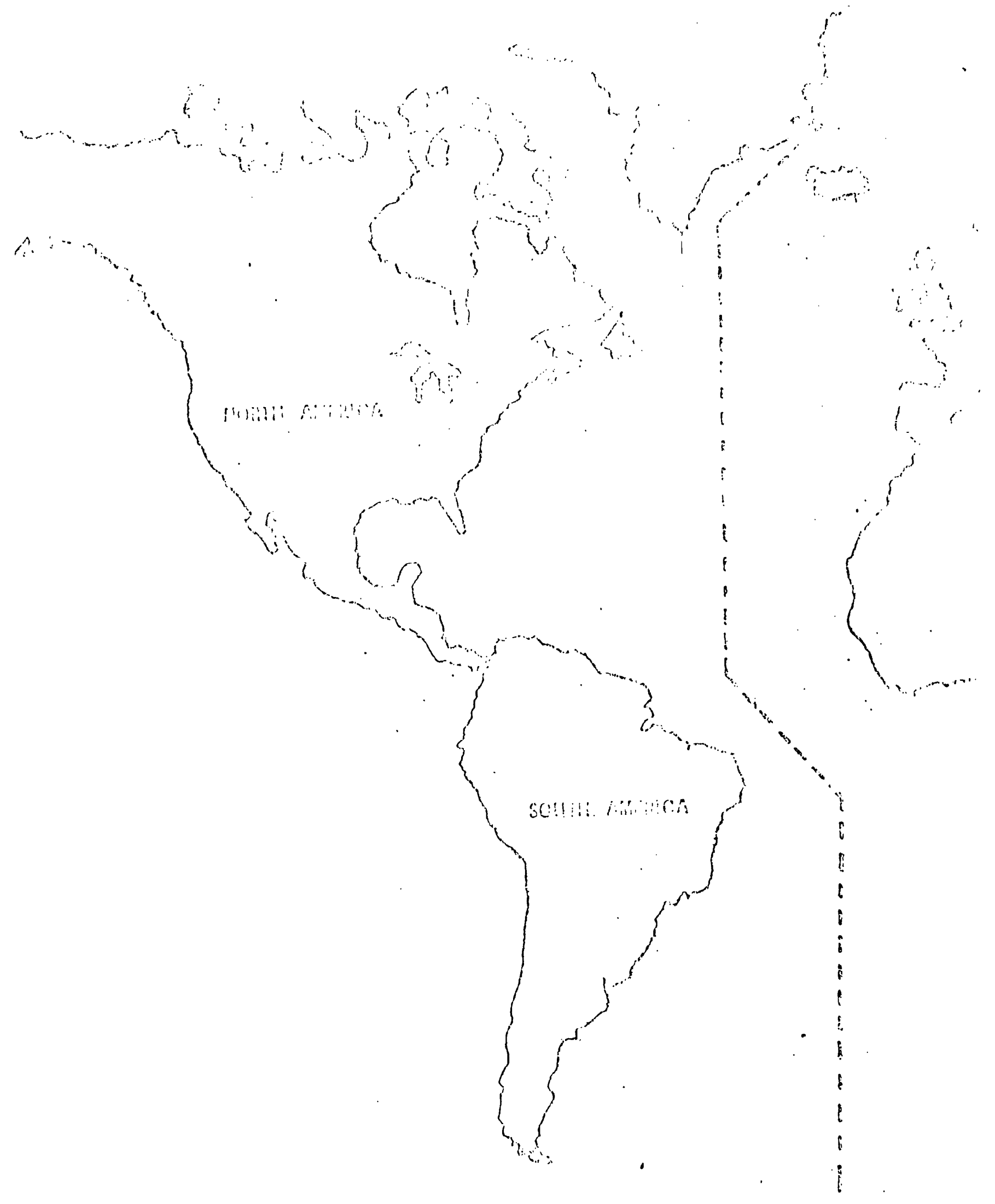




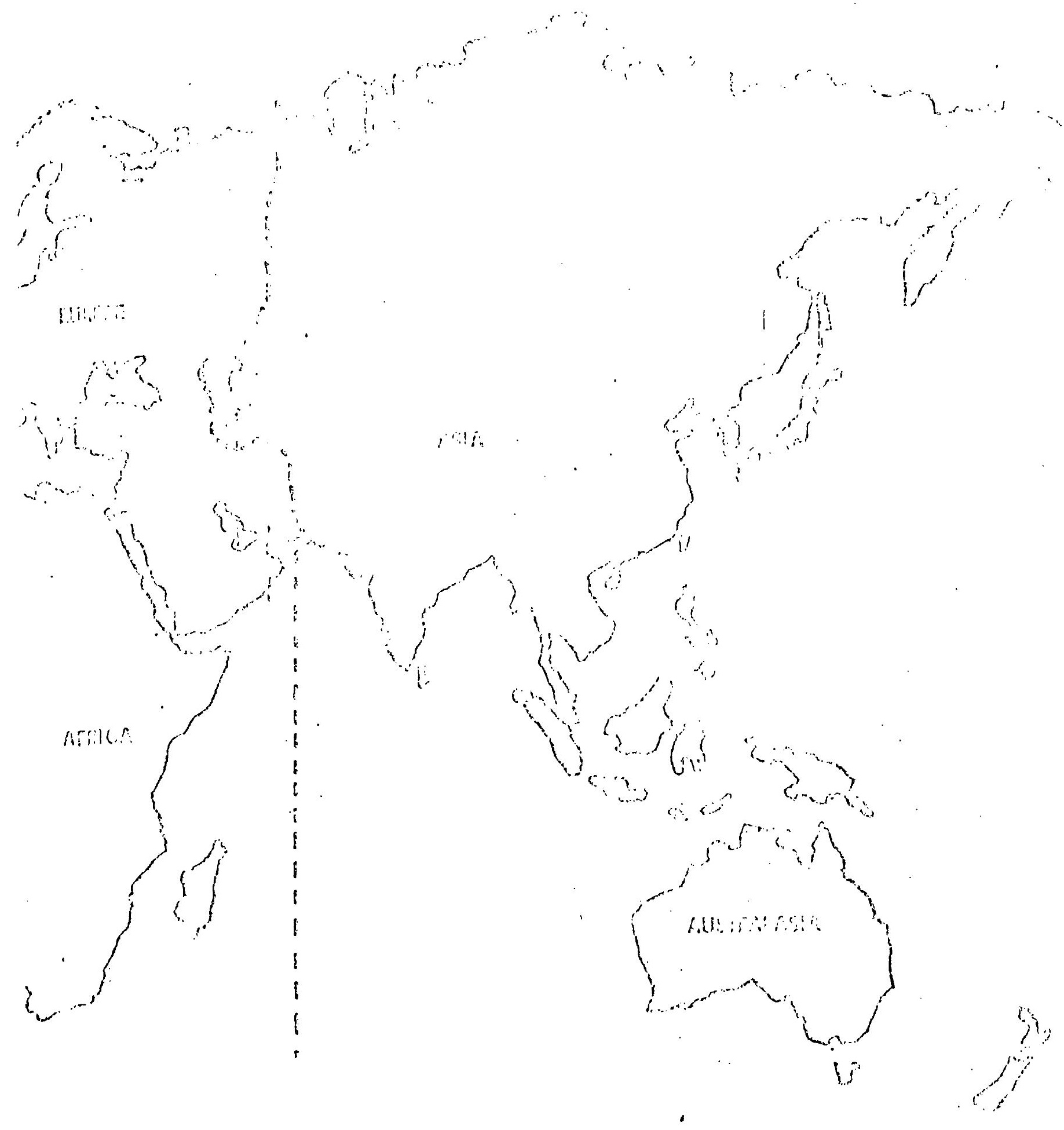


PRACTICAL :

1. Spend two one-hour sessions studying a reputable world atlas. Note the names of countries, oceans, seas, rivers, mountain ranges, cities, lakes and other features. Submit a list of 15 countries you think would receive a large number of information requests from customers of a travel agncy.

2. Compose a form letter which could be used by a travel agent to obtain information from tourist bureaux and tourist boards. Submit a copy of the letter for marking. Send the letter to all the provincial tourist bureaux. This information will used in lesson eleven.

3. Attached is a list of Tourist Boards. Write to those Tourist Boards in which you have an interest. Keep the list and a copy of your letter so that you send for information at a future date. 


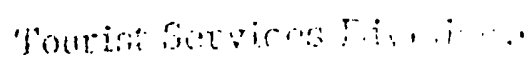

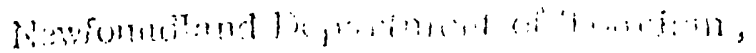

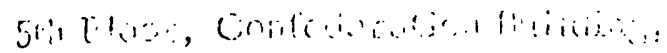

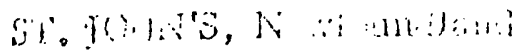

Aner 21,0

$(603) 72 \% \cdot 1711$

Tourist lifonmoljoi contre,

P. 0,100000

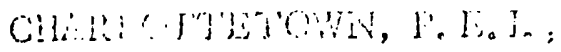

C11) 71.5

(906) $20 \% 2 \%$

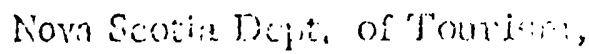

P. O. Bux 456 ,

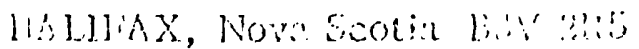

(19) $12 \div-5722$

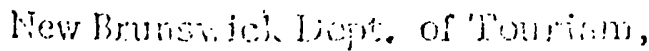

I. O. Io: $] 600$,

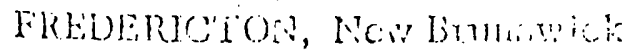

Fis! $5(13$

(1)(1) $153-2510$

Thavel Albora, 1.0255 - 104 sicert,

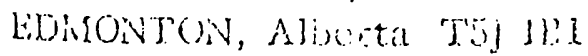
$(403)+24-0474$

Trivelenetic,

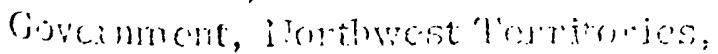

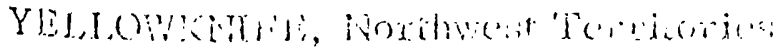
Yom $1:$ in

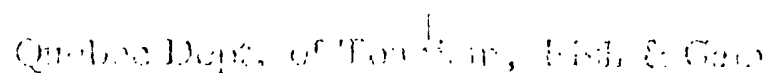

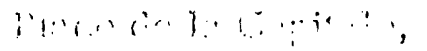

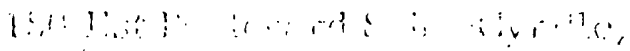

(3)

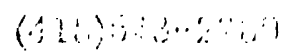

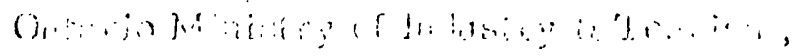

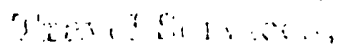

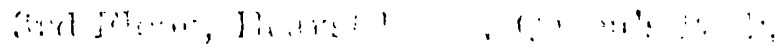

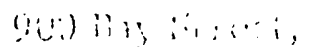

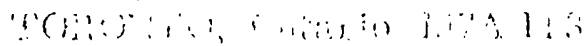

(A)

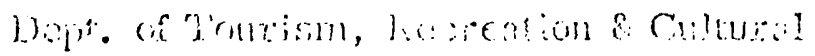
Aflicing,

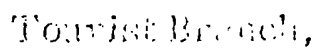

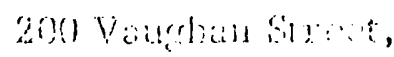

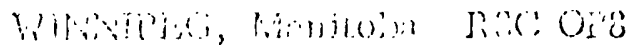

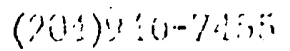

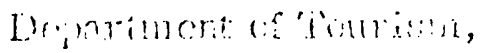

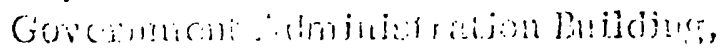
2 mot besio,

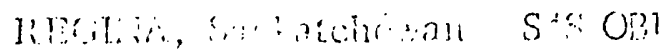

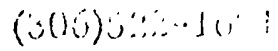

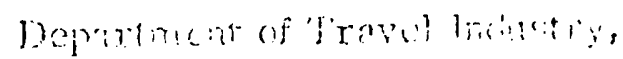

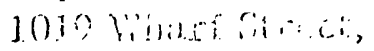

Vor?

(60) $367-63 \%$

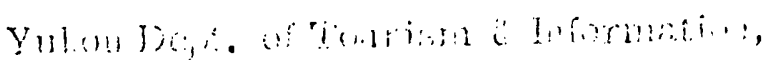

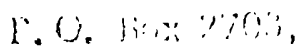

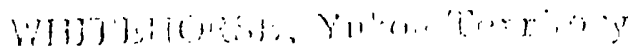




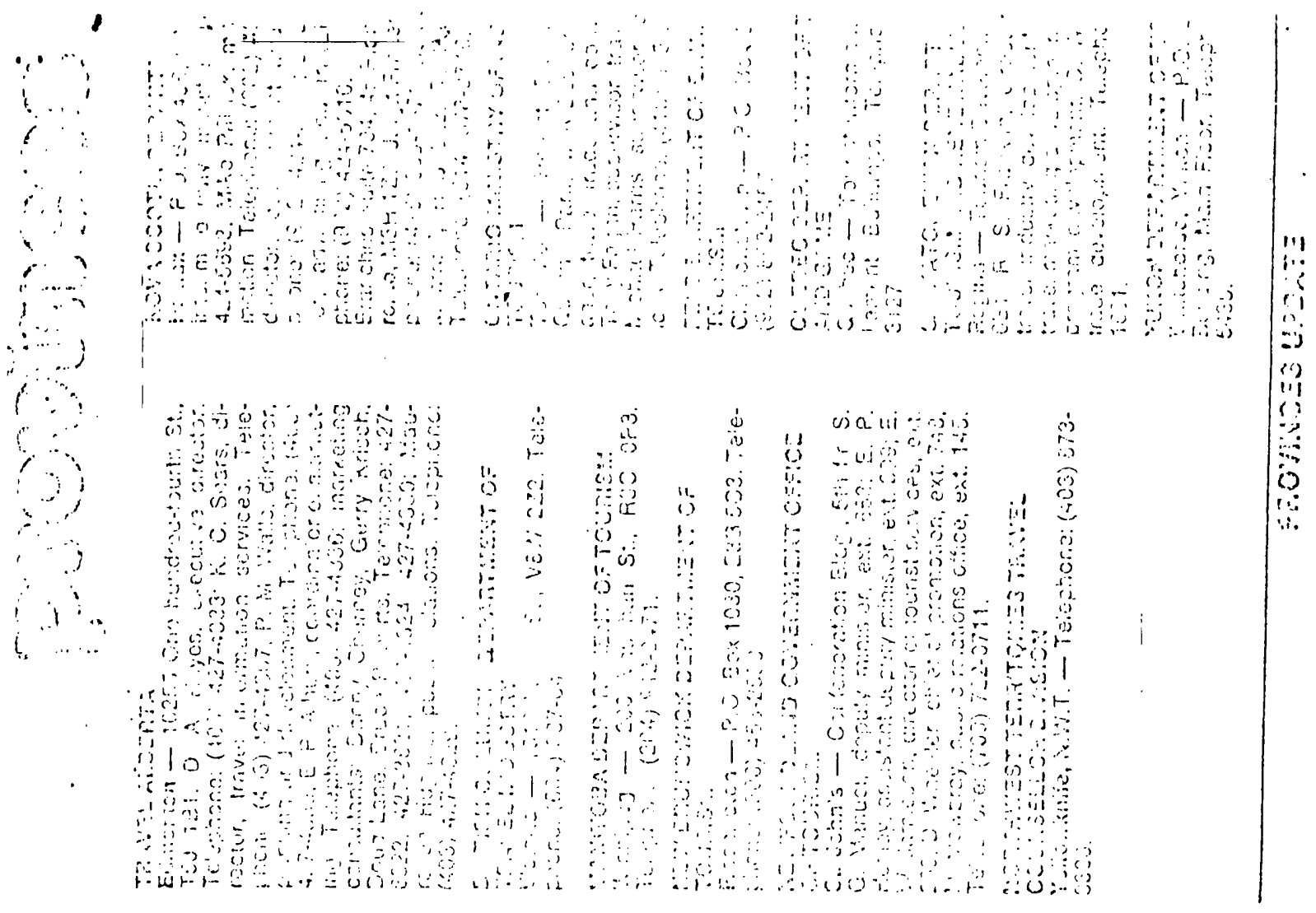

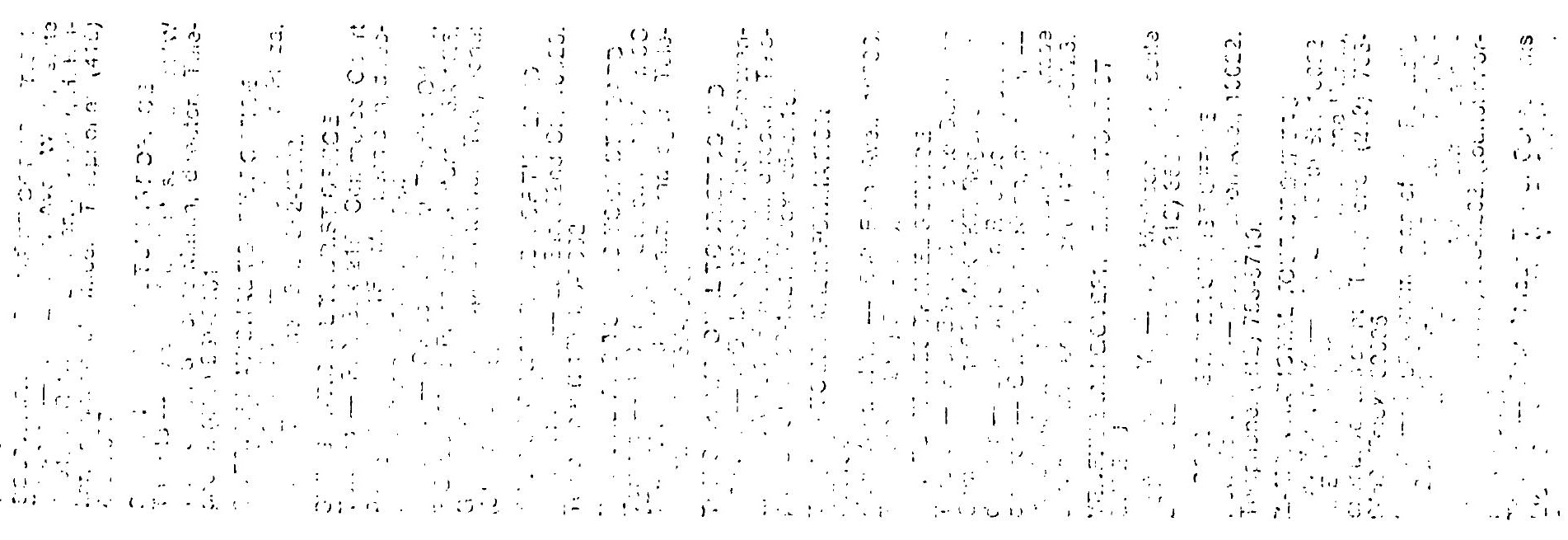
(3) 
TOPIC: $\quad$ Travel Knowledge - General

OBJECTIVES: The'student will use reference materials to develop a general knowledge of holiday destinations and develop skills in evaluating facts about destinations.

REFERENCES: Principles and Procedures of Travel Counselling Pages 237 to 241 , Sections 1 to 5

World Atlas

Travel Guides

Travel Brochures

INSTRUCTOR'S NOTES:

Read through sections 1 to 5 .

\section{$\underline{\text { ASSIGNMENT }}$}

Lesoon 10

1. Locate on the world map attached each of the destinations listed in section 3 of Principles and Procedures of Travel Counselling.

2. Study the chart on page 239. Then select those destinations which are in the western hemisphere and list them separately in order of importance. List any Canadian tourist destinations frequented by Canadians which you feel have been omitted.

3. Bearing in mind that you are researching for and on behalf of your clients who seek your guidance and counsel, assess the merits of the following holiday destinations, using as a guide the criterion given in section 2 of your 
textbook. (pages $237-238$ )
a) Jamaica
b) Edinburgh, Scotland
c) Cairo, Egypt
d) Hong Kong

4. Several vacation activities are listed in section 4 . Combine deep sea fishing, beach activities, gambling and photography and describe one Caribbean destination where a visitor could engage in these activities. Give as much detail as you can as to the availability of the activities.

5. Name towns noted for swimming and water sports in each of the following contries:
a) Jamaica, name three:
b) Florida, name four:
c) Kenya, name one:
d) Republic of South Africa, name two:
e) Spain, name two:
f) France, name two:
g) Hawaii, name three:

Specify nearby town or name of beach. 


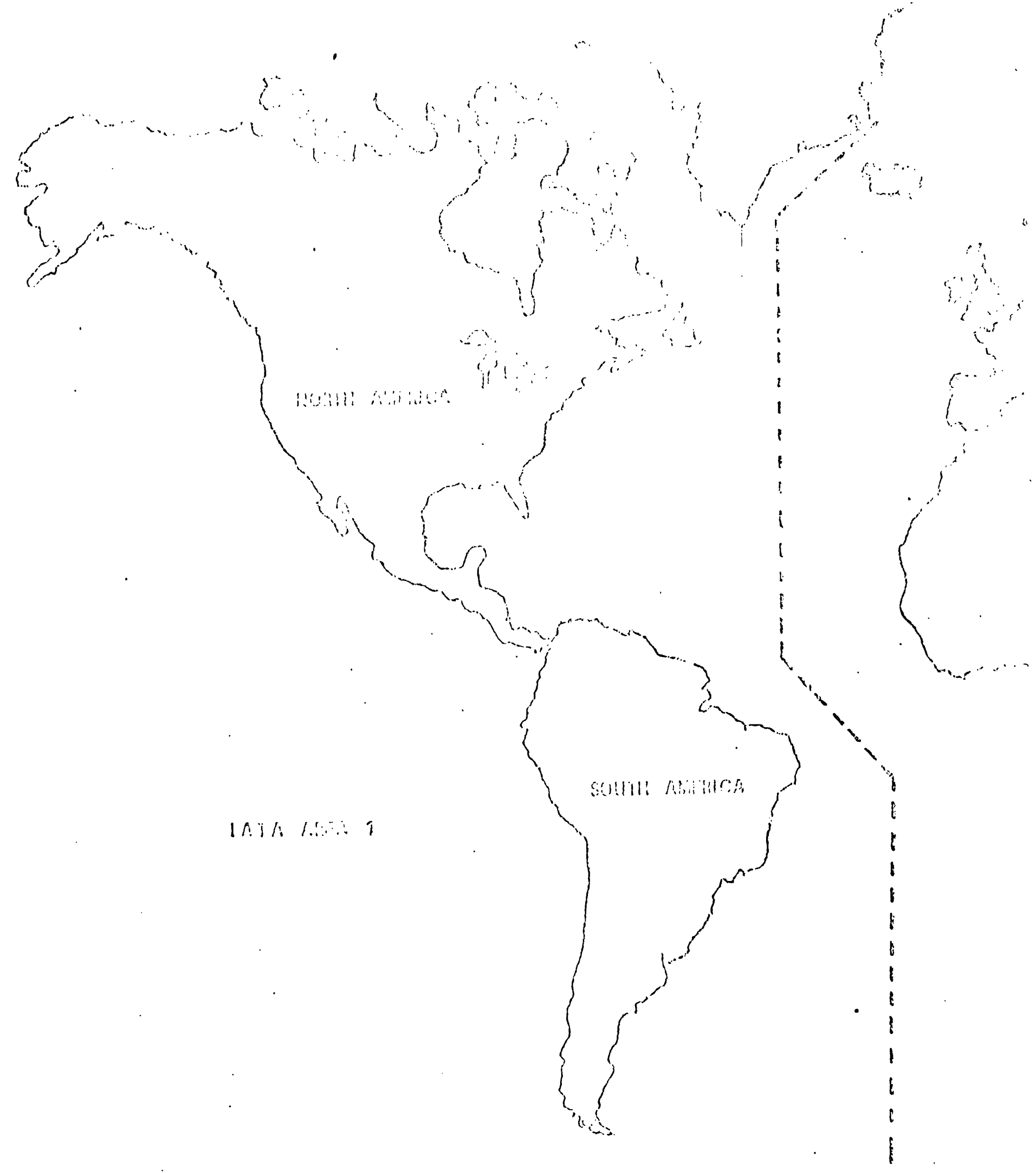




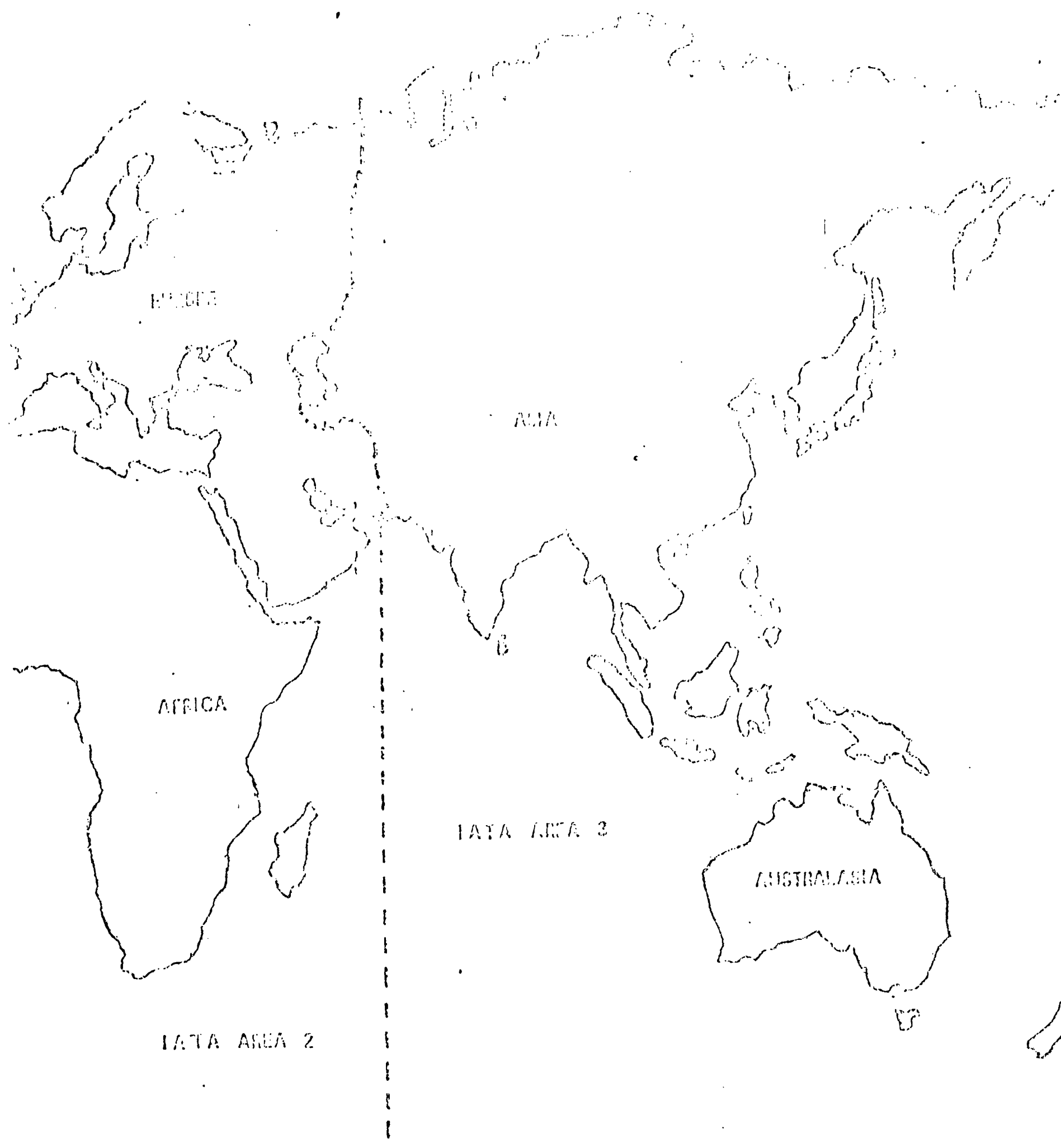




\section{LESSON: $\quad$ Eleven}

TOPIC: $\quad$ Canadian Travel Destinations

OBJECTIVES: The 'student will use Canadian travel materials and develop the knowledge necessary to advise clients on Canadian travel destinations.

REFERENCES: Principles and Procedures of Travel Counselling Pages 238 and 239, Sections 3 and 4

Atlas of Canada

Travel Guides

INSTRUCTOR'S NOTES :

Review the sections 3 and 4 .

\section{ASSIGNMENT}

Lesson 11

1. Name the Canadian Provinces and state the capital of each.

2. State briefly three main tourist attractions for each Province, specify the location of each attraction.

3. Prepare an outline itinerary (day 1, day 2, day 3, etc.) for a 19-day "Island-Hopping" air trip to the Caribbean and Venezuela starting and ending at Miami. Flight schedules are not required. The following stops are to be included; be sure they are in a geographically logical sequence:

Curacao, Caracas, San Juan, Montego Bay, St. Thomas, Bridgetown, Grenada, Port of Spain, Nassau, Martinique, Guadeloupe.

4. Assume a middle aged couple ask you for suggestions about 
spending three weeks in one European country during April. Select one country and, in a one page report, give details briefly about the culture, historical and recreational aspects of the country you recommend, also state local specialities in food and drink and shopping opportunities.

5. For clients who plan to visit foreign countries, specify four things (besides reservations and transportation) that a travel counsellor must always check to ensure that the clients will not neet with any difficulties or delays in entering or departing from foreign countries.

6. Submit Unit Project 1 with this assignment.

7. Using a ballpoint pen or soft pencil, hand draw an outline map of Spain, as large as possible on a page this size. No colouring or fancy lettering please.
a) indicate the bordering seas and/or countries.
b) show the location of the capital city and its name.
c) Indicate: Barcelona, Sevilla, Malaga, Granada, Costa del sol.

8. Describe the following Spanish culinary specialties: Sangria, Paella, Gazpacho, Jerez

9. What are the following: Flamenco, Prado, La Corrida, El Escorial, Alhambra, Paradores.

10. Specify in a geographically logical sequence, twelve cities of touristic interest to be visited on a journey from Stavanger to Jerusalem. 
12. Specify in what body of water the following islands are located:

Scilly

Malta

Orkney

Manitoulin

Bermuda

Grand Bahama

Jersey

Bonaire

Maldive

Hispanol

Cayman

Corfu

Montreal

Minorca

Queen Charlotte

Cuba

Dominica

Eleuthera

Sardinia

Jekyll

Falkland

Delos

Sark

Honshu

Azores 
III UNIT 2:' AIRLINE TARIFFS, FARES AND TICKETING

In order to complete Unit 2 the student should have the following :

1. Instructor's Notes

2. Sample - Official Airline Guide International Edition.

3. Sample - Official Airline Guide North American Edition.

4. Complete Instructions in the use of the North American Edition Official Airline Guide

5. Complete Instructions in the Use of the International Edition Official Airline Guide

6. Pan Am Building Tariff Skills and Units

7. Pan Am Basic Instructions for Writing a Ticket

8. Air Canada - It will Help if You Know.

9. Principles and Procedures of Travel Counselling

\section{Unit 2 Project}

The travel industry has developed a jargon of its own which you must learn in order to communicate with others in the industry. Part of this jargon is the abbreviation of terms, usually using initials. In order that you have a record of these abbreviations for quick reference, an alphabetical list should be made during the programme. 
Start a booklet with lined pages, one page for each letter, tab alphabetically and enter all abbreviations as you encounter them in the programme.

This will be submitted at the end of Unit 4. During the programme it should be used as a useful tool.

LESSON: One

TOPIC: $\quad$ Domestic Route Structures

OBJECTIVES: The student will know the domestic route structure and be able to locate and identify by airline code the major cities served by air.

REFERENCES: Principles and Procedures of Travel Counselling Page 35 .

Air Canada : It will Help If You know

INSTRUCTOR'S NOTES :

Read Introduction page 35 .

1. Route Structures, Canada and the U.S.A.

The term "Domestic Air Travel" refers to air travel wholly within North America, Canada and the United States and including Hawaii, Bermuda and the West Indies.

A brief history of the airline industry is helpful to understand the momentour advancement in the air transportation industry. To emphasize this, a comparison of the aircraft used in 1927 with that used today, only 50'years later is shown below: 
TODAY

Boeing' 40

Boeing 747

1 pilot

Crew of 14

2 passengers $350-470$ passengers

105 m.p.h. $600 \mathrm{~m} \cdot \mathrm{p} \cdot \mathrm{h}$.

Cost $\$ 25,000$

Cost $\$ 25,000,000$

The history of the airline business in Canada can be best explained by looking at the history of our national airline - Air Canada. See Figure 5.

City/Airport Codes and Maps

In order to conserve time and space, three-letter codes are used in lieu of city/airport names. These codes are standard throughout the airline industry. Learning these codes is a matter of memory work. A travel Agent must be familiar with and be able to recall quickly the codes for the major Domestic cities. CANADIAN CITIES - all begin with the letter "Y". Read and complete pages 27 to 35 of Air Canada: It Will Help If You Know. 


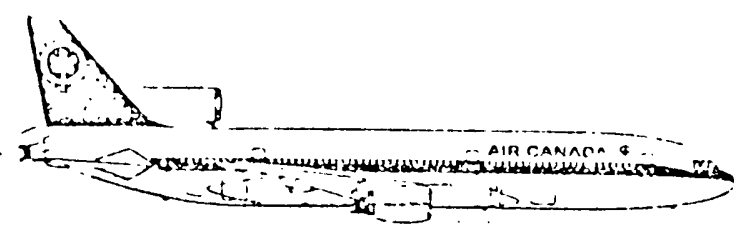

The history of Air Canada probably begins with an editorial by Dr. J. W. Dafoe, editgr of the Winnipeg Free Press. This editorial, written during the early '30s, suggested the idea of a Canadian airline to operate from coast to coast. The idea was taken up in the Canadian parliament and the first step toward realization was taken in 1936 when the Department of Transport (DOT) was formed under the late Hon. C. D. Howe. The Departnient of Transport was charged with developing airway facilities across Canada, including airports, navigational aids and meteorological service.

The Canadian parliament felt that an airline operating coast to coast in Canadit should be Canadian owned and operated. Canadian Airways Ltd., a pioneer in commercial aviation in Canada and the Canadian Pacific Railway Company were approached but both declined to invest in such a financially risky project and, as a result, the Canadian government decided to finance and develop an airline on behalf of the Canadian people, feeling that the future benefits to the nation warranted the initial financial risk.

Aprif 10, 1937 The Trans-Canada Air Lines Act was passed incorporating Trans-Canada Air Lines.

All stock in the company was held by the Government of Canada but later turned over to the Canadian National Railways, wholly-owned by the government. The first president was Mir. S. J. Hungerford, also president of the CNR. A number of CNR elliployees transferred to the new company, bringing with them their valuable knowledge of the transportation industry.

September 01, 1937 Service was inaugurated between Vancouver and Seattle wi,th Lockheed Electras.

At the end of 1937, the fleet consisted of one Stearman (a 2-seater aircraft for training) and five Lockheed Electra 10-passenger aircraft. Total personnel - 71 .

Following are some of the highlights in the company's history from its modest beginning in 1937:

$1938 \mathrm{Mr}$. H. J. Symington became president of TCA

1939 Passenger service introduced on Montreal/Toronto-Vancouver and Lethbridge-Edinonton routes.

Toronto-0ttawa-Montreal service inaugurated

1940 Passenger service introduced Montreal-Moncton

Passenger service introduced Toronto-London-Windsor

$1941^{\prime}$ Service extended from inoncton to Halifax

Toronto-New York service inaugurated

1942 Moncton-Sydney-Gander-St. John's, Nfld. service inaugurated 
1943 Vancouver-Victoria service inaugurated

Canadian government Trans-Atlantic Air Service inaugurated Montreal-Prestwick with converted Lancaster aircraft

1945 DC-3 aircraft introduced initially Toronto-New York

1946 Toronto-Chicago service inaugurated

Regina-Calgary-Edmonton routing introduced on transcontinental flights

Toronto:Cleveland service inaugurated

Trans-Atlantic service extended from Prestwick to London

1947 Halifax-Yarmouth-Saint John-Boston service inaugurated North Star aircraft were introduced, initially on TransAtlantic service. North Stars were TCA's first aircraft wi th pressurized cabins. They were powered with Rolls Royce engines mounted on Douglas airframes and built under the direction of TCA by Canddair in Montreal. The Canadian government Trans-Atlantic operations were now taken over as part of the TCA system.

Shannon, Ireland was inaugurated as a stop on Trans-Atlantic services

$1948 \mathrm{Mr}$. Symington retired as president to be replaced by Mr. G. R. McGregor

Montreal/Toronto-Bermuda service inaugurated

Montreal-Toronto-Nassau-Kingston-Port of Spain service inaugurated

1949 Headquarters offices relocated from Winnipeg to Montreal Bridgetown, Barbados stop introduced on Bermuda-Port of Spain service

1950 Montreal-New York service inaugurated

Tampa, Florida service introduced on Caribbean service

1951 Trans-Atiantic service extended from London to Paris

1952 Trans-Atlantic service extended from London to Düsseldorf

1953 Montego Bay, Jamaica, stop introduced on southern services

1954 Mexico City service inaugurated on extension of flight to Tampa

Super Constellation aircraft introduced initially with a first class seating capacity of 63

1955 Viscount aircraft introduced. TCA was the first airline in North America to operate turbo-propeller aircraft. Montreal-Quebec-Bagotville-Seve.r Islands service inaugurated Service to Mexico City discontinued 
1958 Service to Bryssels inaugurated

Service to Zürich inaugurated

-Antigua stop introduced on southern routes

1959 Service to Vienna inąugurated

1960 Canada-UK pool service with BOAC inaugurated

DC- 8 jet aircraft introduced to Montreal-TorontoVancouver route

1961 Vanguard aircraft introduced

1962 Retirement of Super Constellations made TCA one of the first intercontinental airlines to operate an all-turbine fleet

1963 Reservec 1, TCA's first automated reservations system, was fully implemented

1965. Company's name was officially changed to Air Canada

Service to Freeport, Bahamas was inaugurated

1966 DC-9 equipment introduced

Service to Frankfurt was inaugurated replacing service to Düsseldorf

Tampa service was extended to Miami

Copenhagen and Moscow service inaugurated, introducing a new pool service between Montreal and Moscow wi th Aeroflot, the USSR national carrier

1967 Montreal-Toronto-Los Angeles service was inaugurated

Pool service with Irish International Airlines commenced between Montreal and Shannon/Dublin

Long-body (stretched) DC-8s introduced

$1968 \mathrm{Mr}$. G. R. McGregor retired as president and chairman of the board

Mr. Yves Pratte, a Quebec City lawyer, was named chairman of the board and chief executive officer and Mr. John R. Baldwin, previously Deputy Minister of Transport, was named president

1969 Air Jamaica Limited, in which Air Canada has a substantial financial interest, comunenced operations between Jamaica and Miami and Jamaica and New York

Service to Brussels reinstated after having been suspended for several years 
197.0 Pool service between Montreal and Prague with Ceskoslovenske. Aeroliriie, Czechoslovakia's national carrier, commenced.

Air Canada underwent a niajor reorganization to improve efficiency and bring it in line with changing conditions.

ReserVec I was replaced by Reservec II. This is one of the most highly sophisticated computerized systems in operation today, in or out of the air transportation industry.

1971 Delivery of 3 Boeing 747 's, the world's largest commercial aircraft and first generation wide-body aircraft.

1972 Air Canada submitted a bid on a one-third interest in Wardair, Canada's largest charter airline.

Rapidair service between Montreal and Toronto commenced.

Termination of the pool agreement with Irish International Airlines.

The last Vanguard was phased out of service.

1973 Delivery of the L-1011 fleet, second generation wide-body aircraft, commenced.

Completion of commercial cooperative agreements with Air France and Lufthansa German Airlines for cooperative flanning and developing of applicable travel markets.

The Toronto operation moved to Terminal 2, a new 42-million dollar terminal to be used exclusively by Air Canada and its associates, Wardair and Air Jamaica.

Delivery of the fourth Boeing 747.

Multi-million dollar contract negotiated to equip Pacific Western Airlines with ReserVec II facilities.

Econair incorporated as a subsidiary for the processing of passengers on Air Canada charter flights.

Ralph T. Vaughan was appointed president on retirement of John $R$. Baldwin.

1974 The Vickers Viscount, after 19 years of outstanding performance, was phased out of service.

Air Canada commenced operations into Munich as an extension of its Frankfurt service.

2 more Boeing 747 's were delivered.

Service tetween Edmonton/Calgary and San Francisco commenced.

Boeing 727 aircraft were added to the Air Canada fleet.

Venturex was developed as a wholly-owned subsidiary of Air Canada

to operate two separate divisions--Econair Canada and Canaplan.

Eastern Provincial Airways was added to the ReserVec II system.

This, briefly, is the story of Air Canada. From its early stages in 1937 with a 122 -mile route, six aircraft and 71 employees, it has grown and expanded to its present status with more than 80,000 miles of routes, spanning a quarter of the globe and serving over 60 communities in Canada, the United States, Europe and the Caribbean with a modern fleet and employing in excess of 20,000 personnel. 


\section{ASS IGNMENT}

Lesson 1

1. What is the name of the licensing body for air services in Canada?

2. Name the transcontinental and regional airlines which operate in Canada - specify the regions served by each.

3. Canada has three groups of air carriers, what are the four American groups and give two examples of each.

4. What is a bilateral agreement?

5. Decode the following:

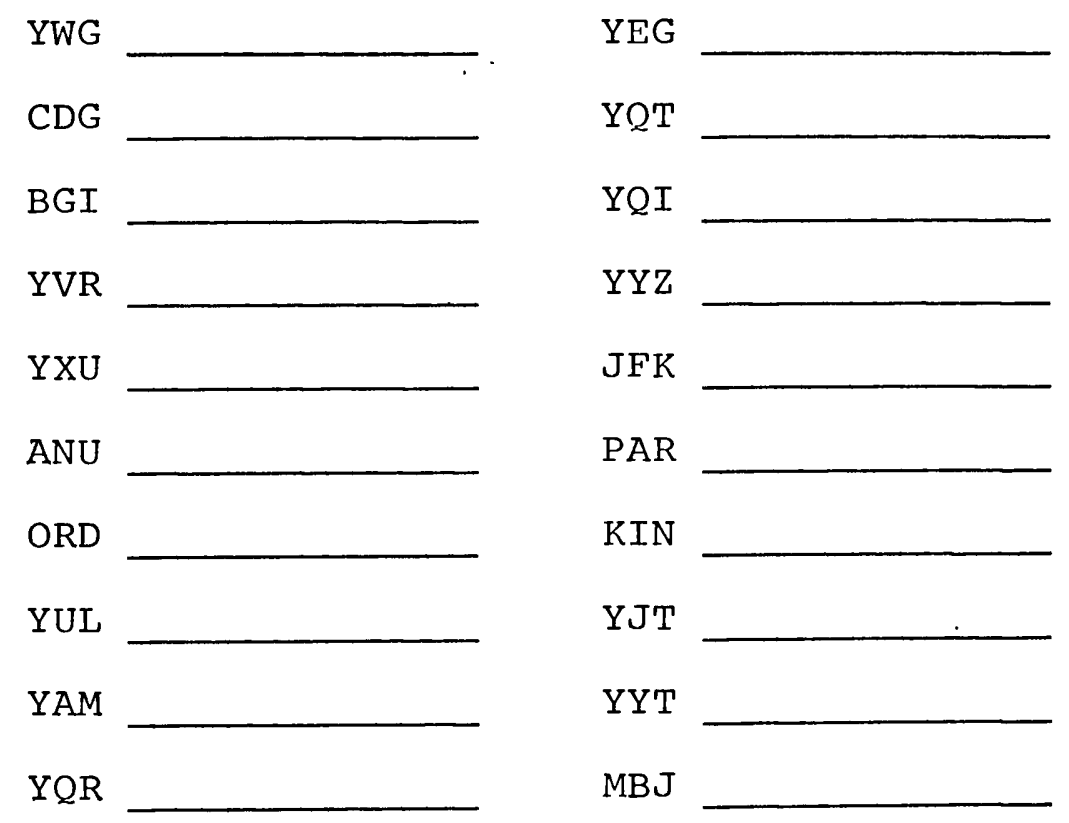

6. Complete the city designator codes for each of the following:

Nassau

Boston

Moscow

Cleveland

Saint John

Thunder Bay

Saskatoon
Halifax

Fredericton

Victoria

Toronto

Moncton

Zurich

Winnipeg 
7. Complete city codes on the following blank maps. 


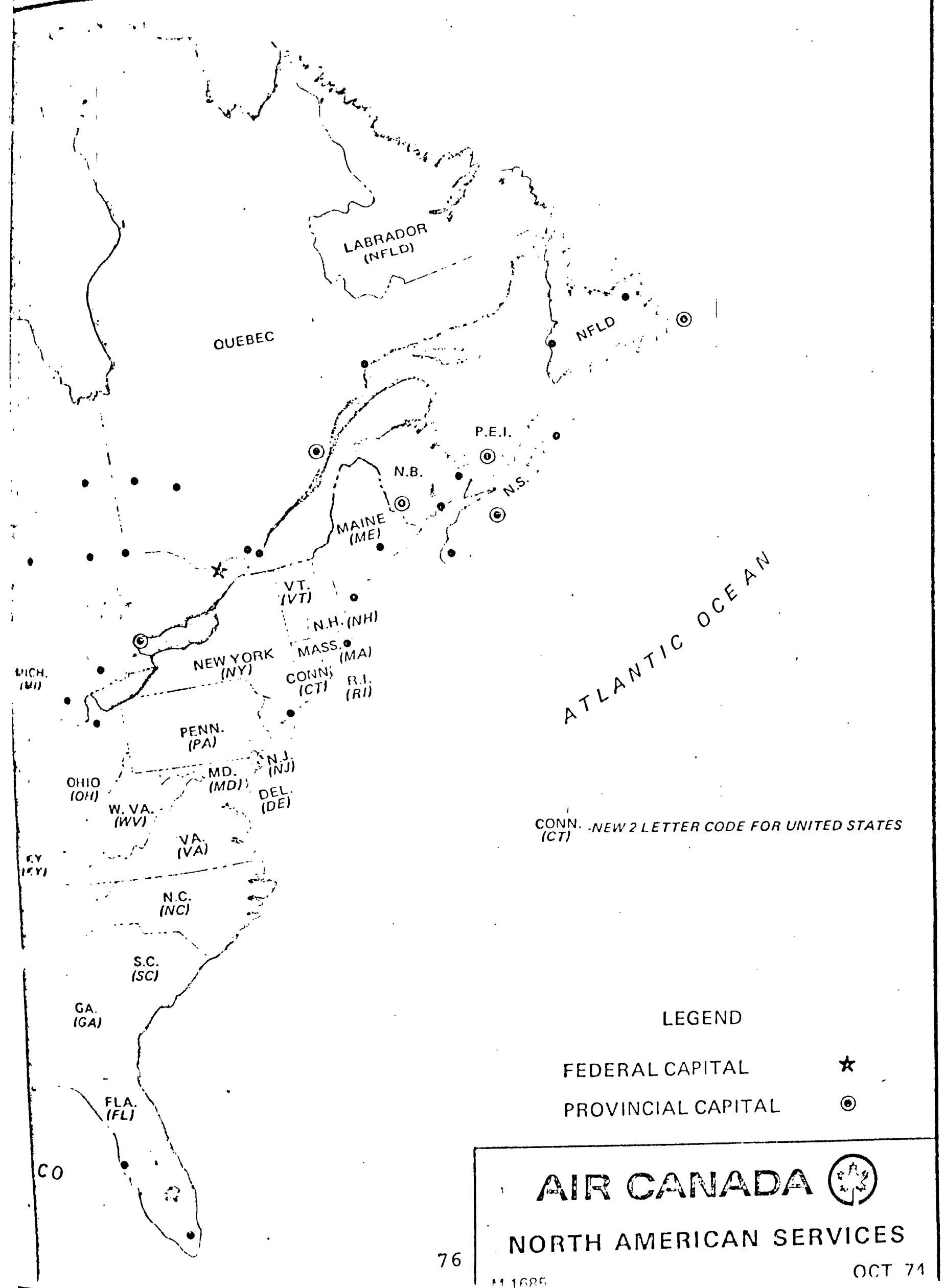




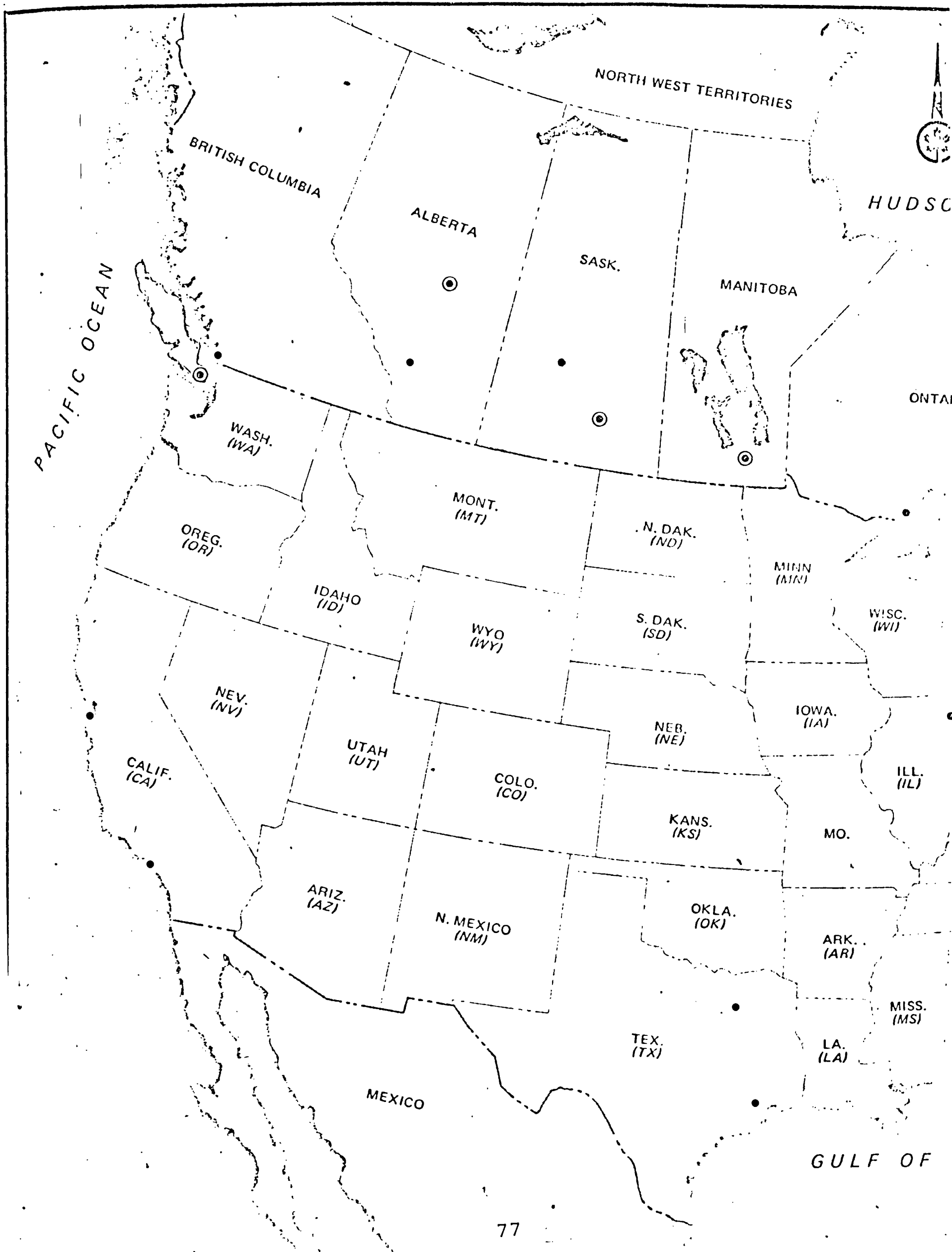




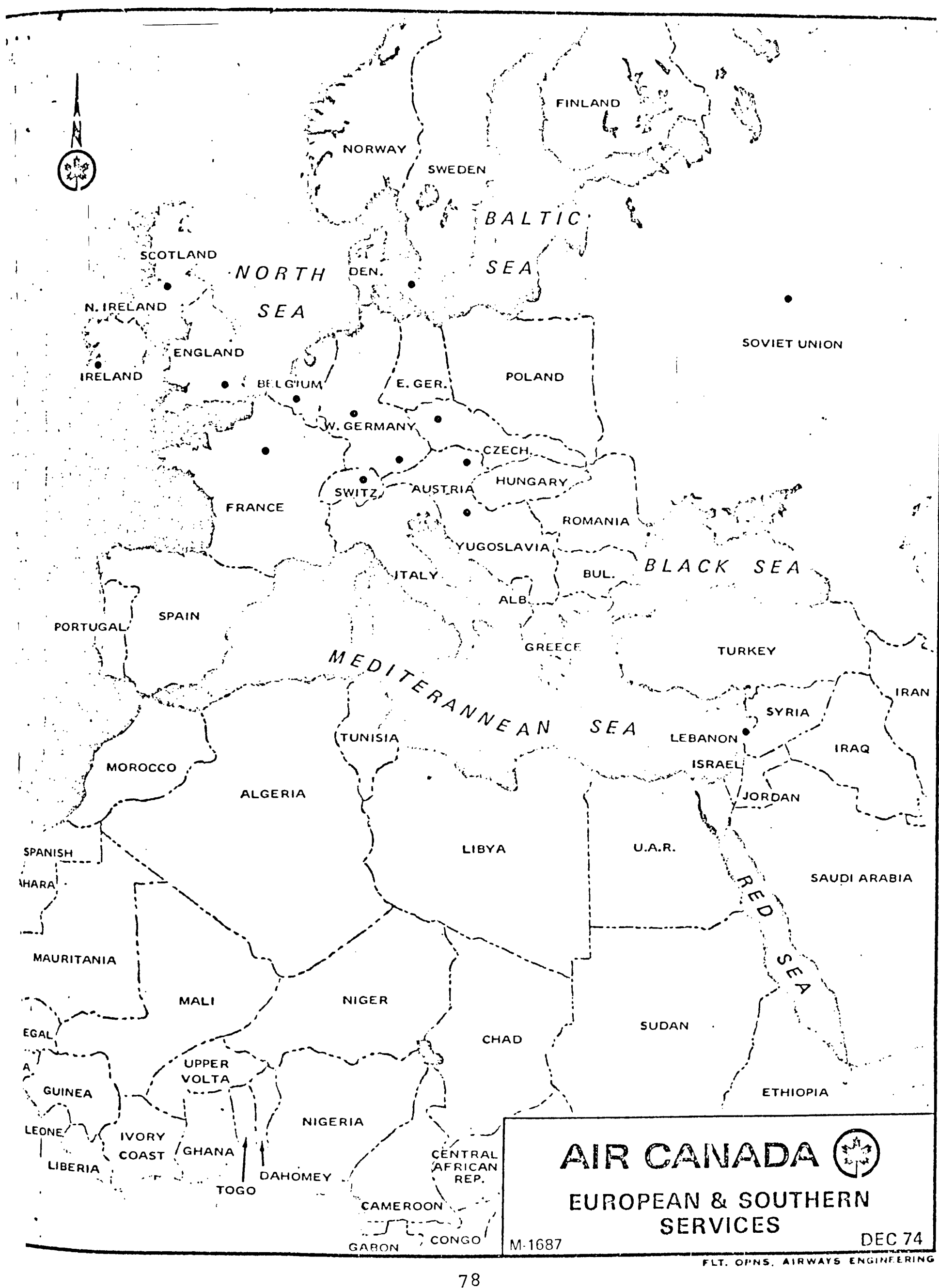




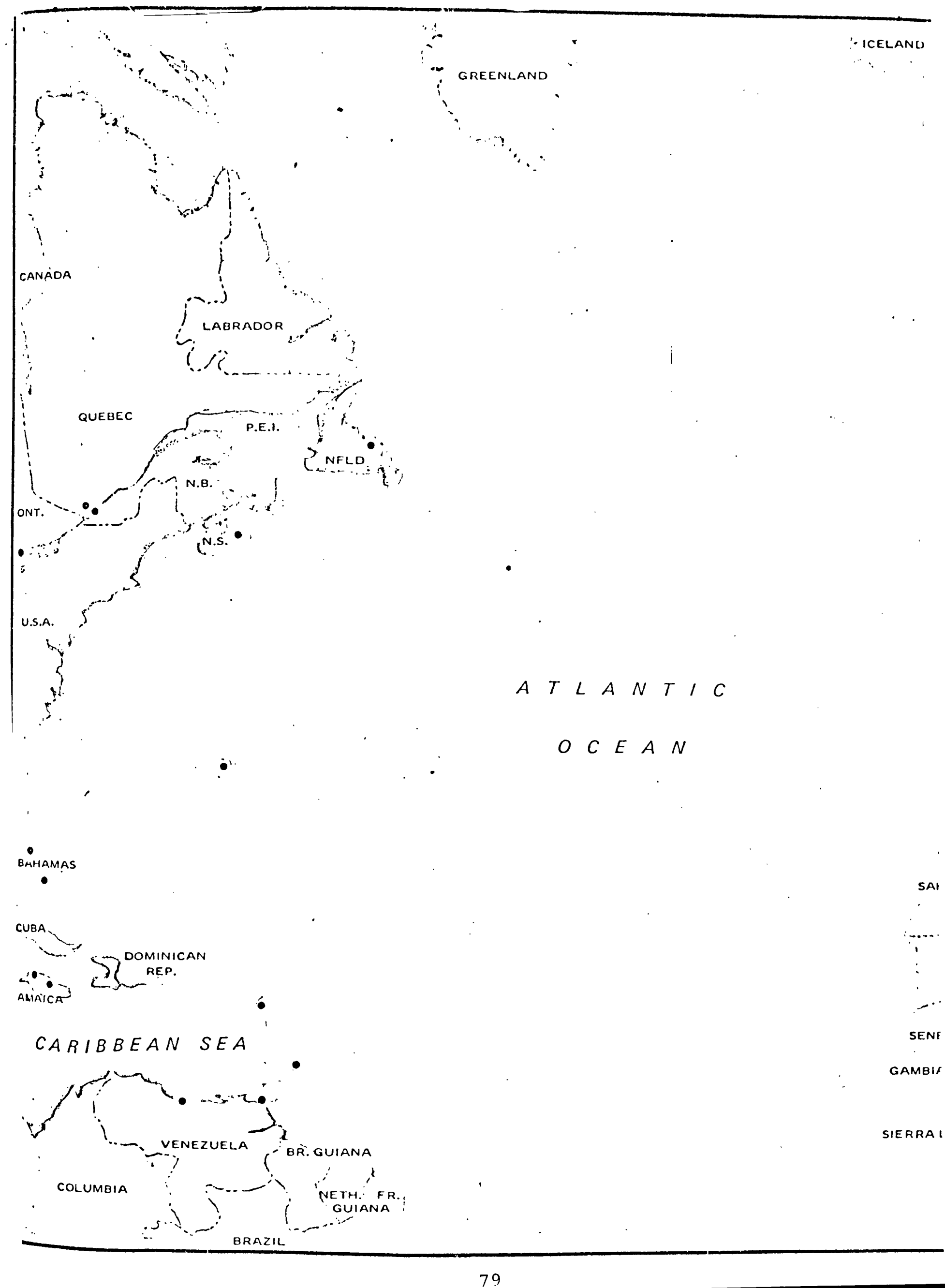




\section{LESSON : $\quad$ TwO}

TOPIC: North American Edition Official Airline Guide (NAÓAG)

OBJECTIVES: The student will be able to use the NAOAG to prepare passenger flight itineraries, and correctly answer passenger's questions concerning flight frequencies, number and location of stops, class of service, meals, equipment types, ground transportation, correct airport of departure and arrival and minimum connecting flight times.

REFERENCES: Complete Instructions in the use of North American Edition Officiall Airline Guide Air Canada - It Will Help If You know Official Airline Guide (OAG) Page 63 to 66 Sample copy of the North American Edition Offical Airline Guide

INSTRUCTOR'S NOTES :

Read Pages 63 to 66 Air Canada - It Will Help If You Know and Official Airline Guide (OAG) pages 63 to 66 . Complete the programmed instruction booklet in the use of the North American Edition of the Official Airline Guide.

\section{ASSIGNMENT}

Lesson 2

1. How many times a year is the NAOAG printed?

2. Name 10 countries which are represented in the NAOAG.

3. Using the NAOAG, what do the following designate: $\mathrm{AA}$ OK $\mathrm{BA}$ MX 


$\mathrm{SK}_{\mathrm{SW}}^{\mathrm{TW}} \mathrm{PW}_{\mathrm{PV}}$

JM

CP

$\mathrm{CU}$

$\mathrm{BN}$

$\mathrm{AF}$

4. Using the NAOAG, what do the following designate:

SJC
YUL
MEY
YET
MTY

LIT

HOU

HNL

$\mathrm{CRW}$

CHI

BGI

PTP

5. Using the NAOAG, find the codes for the following airlines and cities :

San Fransisco

Olympic Airways

Las Vegas

Air Canada

Atlanta

Delta Airlines

Daytona

Saskatoon

Western Airlines

Portland
Edmonton

Fort Lauderdale

British Airways

Hawaiian Airlines

Acapulco

Seattle

Air Midwest

Air Sunshine

Charlottetown

Eastern Airlines 
6. Using NAOAG, find the Aircraft, class of service, frequency code, food service, fares or Car Rental Company for the following abbreviations.

\begin{tabular}{l} 
LIO \\
DC9 \\
CES \\
$\mathrm{ZICR}$ \\
$\mathrm{F}$ \\
7 \\
$\mathrm{~B}$ \\
$\mathrm{LH}$ \\
$\mathrm{YZ}$ \\
747 \\
$\mathrm{Y} 62$ \\
$\mathrm{DHC}$ \\
$\mathrm{FO}$ \\
3 \\
\hline
\end{tabular}

7. Using your NAOAG, locate the following flight itineraries, give code and name of cities:

$\begin{array}{lll}\text { FLIGHT } & \text { ORIGIN } & \\ \text { CP } 563 & \\ \text { EA } 80 & \\ \text { DL } 168 \\ \text { NW } & 245 \\ \text { UA } 876\end{array}$


8. What information does each column in the following NAOAG entry give you?

To: New York, N.Y.

FROM: Houston, Texas

$\begin{array}{lllllllllll}X 6 & 5: 15 \mathrm{p} & \mathrm{I} & 9: 12 \mathrm{p} & \mathrm{E} & \mathrm{FA} & 56 & \mathrm{~F} / \mathrm{Y} & 727 & \mathrm{D} & 0\end{array}$
(a) (b)
(c)
(d)
(e) (f) (g)
(h)
(i)
(j) (k)

(a)

(b)

(c)

(d)

(e)

(f)

(g)

(h)

(i)

(j)

(k)

What would you tell a client about this flight?

9. What information would you tell your client about the following NAOAG entries?

(a) TO: CHICAGO, IIl.

FROM: ATLANTA, Ga.

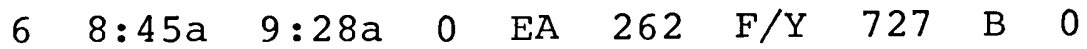

(b) TO: PITTSBURGH, Pa.

FROM: ST. LOUIS, MO.

$\begin{array}{lllllllll}7: 00 \mathrm{a} & (: 20 \mathrm{a} & \mathrm{P} & \mathrm{AL} & 984 & \mathrm{~S} & \mathrm{D} 9 \mathrm{~S} & \mathrm{~B} & 1\end{array}$ 
(c) TO: MIAMI, Fla.

FROM: CHICAGO, III.

$457: 30 \mathrm{a}$ M 2:20p SO 211 S DC9 BS 5

LESSON : $\quad$ Three

TOPIC: International Route Structures

OBJECTIVES: The student will know the International Route

Structure and be able to locate and identify

major cities by code.

REFERENCES: Principles and Procedures of Travel Counselling

Pages 35 and 36 .

PanAm - Building Tariff Skills

Air Canada - It Will Help If You Know, page 1 to 14

INSTRUCTOR'S NOTES :

Read Section 2. Route Structures, International

Read and learn the International City Codes in the Map Folio, Green.

Read "PanAm Map Folio" introductory letter and learn the International City Codes in the enclosed seven maps. The international city codes are often abbreviations of the city name and, therefore, easier to memorize than the Canadian city codes.

Regulation of Scheduled Air Services

The objective of regulations in the air transport industry is to provide safe adequate service. All regulations are formulated with this goal in mind. 
Throughout the programme you will be using systems which are uniform for all airlines. Without the mutual co-operation of the airlines directed towards this end, the air travel industry and your work as a travel agent would be infinitely more complicated.

Read: Air Canada, It Will Help If You Know, pages 1 to 14

\section{ASSIGNMENT \\ Lesson 3}

1. What are agreements called between two countries which negotiate àir traffic rights?

2. What is a "gateway"?

3. What is the name of the Canadian body which regulates airlines in Canada?

4. a) What is the U.S.A. air regulatory body?

b) What is the International Agency and where is it headquartered?

5. What government agency regulates prices in:
a) Canada?
b) U.S.A.?

6. What is the main objectives of the government regulation of air services?

7. Give the names of the city and country for the following codes : 


$\begin{array}{lll}\text { CODE } & \text { CITY } \\ \text { POS } \\ \text { SFO } \\ \text { SAO } \\ \text { GLA } \\ \text { BOG } \\ \text { TLV } \\ \text { CPT } \\ \text { MNL } \\ \text { DKR } \\ \text { DEL } \\ \text { MEB } \\ \text { MSP }\end{array}$

8. What are the codes and countries for the following cities? CODE CITY COUNTRY

Wellington

Seoul

Casablanca

Oslo

Lima

Dallas

St. Croix

Kona

Colombo

Nicosia

Dublin 
TOPIC: International Air Transport Association (IATA) OBJECTIVES: The student will understand the functions of IATA, be able to identify terms used in the air travel industry, identify the IATA areas and find information in the Air Tariff Books.

REFERENCE: Principles and Procedures of Travel Counselling Page 36 to 41 Panam - Building Tariff Skills Unit I Lessons 1 to 3 .

INSTRUCTOR'S NOTES :

Read International Air Transport Association (IATA) page 36 and 37 .

Complete lesson 2, The Three Worlds of IATA, Unit I, PanAm Building Tariff Skills.

Read (i) How International Airline Fares and Rates are Made, pages 39 and 40 .

(ii) Tariffs, pages 40 and 41 .

Complete Lesson 3, Where the Fares Are, Unit I, PanAm Building Tariff Skills.

\section{ASSIGNMENT}

Lesson 4

1. What is IATA? What are its objectives? How are these objectives being achieved?

2. What are five of the major criteria that travel agencies must fulfil in order to become an "approved passenger sales agency"? 
3. Specify those areas of the world that are defined by the IATA as :
a) Domestic
b) International

4. What are the three IATA Traffic Conferences?

5. Where are the offices of IATA?

6. What is the "Bible" for correct air fares?

7. The Air Tariff consists of how many volumes?

LESSON : $\quad$ FIVE

TOPIC: International Edition Official Airline Guide

OBJECTIVES: The student will be able to use the IOAG to prepare passenger flight itineraries and correctly answer passenger questions concerning flight frequencies, number and location of stops, class of service, meals, equipment types, ground transportation, correct airport for departure and arrival and minimum connecting flight times.

REFERENCES: Complete Instructions in the Use of International Edition Official Airline Guide. Air Canada - It Will Help If You Know, Pages 67 to 69 .

INSTRUCTORS'S NOTES :

Complete the programmed instruction booklet in the use of the International Edition Official Airline Guide. 
Read the Air Canada, Official Airline Guide pages 67 to 69 .

\section{$\underline{\text { ASS IGNMENT }}$ \\ Lesson 5}

1. How many times a year is the IOAG printed?

2. State in which of the OAG editions you would find the following flights listed. Find each in your sample OAG's and note the page:

FLIGHT

OAG EDITION PAGE

Aruba, Netherland Antilles from

Caracas, Venezuela

Buffalo, N.Y. from Honolulu, Oahu,

Hawaii

Cleveland, Ohio from Vienna, Austria

Toronto, Canada from Port of Spain,

Trinidad \& Tobago

Tehran, Iran from London England

Monserrat, Leeward Islands from

New York, N.Y.

Nairobi, Kenya from Los Angeles, Calif.

Tokyo, Japan from Buenos Aires,

Argentina

Athens, Greece from Toronto, Ont.

Phoenix, Arizona from Toronto, Ont.

Rome, Italy from Winnipeg, Man.

Calgary, Alta. from Val d'or, Que.

Aculpulco, Mexico from Vancouver, B.C. 
3. What are the local airline taxes or departure taxes for the following countries? State the tax in local currency and in Canadian dollars.
a) Barbados
b) Bermuda
c) Puerto Rico
d) Jamaica
e) England

4. What are the connecting time requirements in the following cities?

CITY
a) Honolulu, Hawaii
b) Calgary, Alta
c) Barbados, W.I.
d) Montreal, Canada
e) Gander, Canada
f) Toronto, Canada
g) London, Heathrow INT'L TO DOMESTIC INT'L TO INT'L 
d) London, Heathrow to Buenos Aires via New York. Department Saturday with a one week stop-over in New York.

e) London, England to Johannesburg, South Africa with a Tuesday departure, closest flight to noon.

LESSON : $\quad$ Six

TOPIC: IATA - Reading the Air Tariff I

OBJECTIVES: The student will be able to obtain information needed to quote a fare from the Air Tariff.

REFERENCES: Principles and Procedures of Travel Counselling Page 41,49 to 54 .

PanAm Building Tariff Skills Unit I, Lesson 4 and 5 .

INSTRUCTOR'S NOTES :

Read (iii) Reading the Tariff page 41

Complete Lesson 4, Reading the Tariff, Unit I, Pan Am Building Tariff Skills.

Complete Lesson 4, Finding More Fares, Unit I, Pan Am Building Tariff Skills.

\section{ASS IGNMENT}

Lesson 6

1. With regard to fare charged, what is the significance of the date of commencement of travel? ,

2. For a flight from YYZ to FRA the Air Tariff would quote the fare in:

a)

b) 
3. Describe a "Normal Fare".

4. Name four general restrictions which make "Special Fares".

5. Describe the following:
a) Individual Inclusive Tour
b) Student Fare
c) Affinity Group
d) APEX

6. What is the title of the Table used in the Air Tariff describing the classes of service codes?

7. What information is found in the eight columns to the right of the Sideline Cities in the Air Tariff yellow pages?

8. Give the full name for the following abbreviations:
a) $\mathrm{ON}$
b) $\mathrm{Y}$
c) $\mathrm{Z}$
d) LAX
e) $\operatorname{YOE} 45$
f) $\mathrm{RT}$
g) $Y Y Z$
h) YVR
i) $\mathrm{FCU}$
j) TYO
k) YHE 45-RT
1) MPM
m) JYE
n) $\mathrm{F}-\mathrm{ON}$

9. What is a fare construction unit?

10. What colour pages are the rules in the Air Tariff printed on?

11. Explain "MAP RTE NO". Where would you find information about an entry? 
12. Give the full name and explain the following Global Indicators :
a) $\mathrm{AP}$
b) $\mathrm{EH}$
C) $\mathrm{EU}$
d) NP
e) $\mathrm{PO}$
f) $\mathrm{TS}$
g) $\mathrm{WH}$

13. Using the Air Tariff pages reproduced on 49 to 54 of the Principles and Procedures of Travel Counselling, answer the following questions:

1) Itinerary Toronto to Belfast F-OW
a) In which book of the Air Tariff is the fare located?
b) Which city is the Headline City?
c) What is the currency of the Headline City?
d) What is the applicable fare in the currency of the Headline City?
e) What is the applicable fare in Fare Construction Units?
f) Are there any special rules which apply to the fare?
g) What is the applicable mileage?

2) Itinerary Toronto-Khartoum YLE21.

a) In which book of the Air Tariff is this fare 


\section{found?}

b) Which city is the Headline City?

c) What is the Currency of the Headline City?

d) What is the applicable fare in:

i) Currency of Headline City?

ii) FCU'S?

e) Are there any special rules which apply to the fare? If so what is the rule number?

f) What is the maximum permitted mileage?

3) Itinerary YVR-MAD. Economy 45 day Excursion at high season.

a) In what book of the Air Tariff is this fare found?

b) Which city is the Headline City?

c) What is the currency of the Headline City?

d) What is the applicable fare in:

i) Currency of the Headline City

ii) $\mathrm{FCU}$ 'S

e) Are there any special rules, if so what number?

f) What is the Maximum Permitted Mileage?

14. What is an Add-On far? What colour pages do you find the Add-On fares on in Book 2A?

15. If you cannot find a fare in the yellow pages of the Air Tariff, give two other places you could look for it? 
LESSON : $\quad$ Seven

TOPIC: $\quad$ Reading the Air Tariff II

OBJECTIVES: The student will be able to locate a "turnaround" point and quote a stop for a multi-stop itinerary and list and locate three sets of rules which govern fares in the Air Tariff.

REFERENCES: Principles and Procedures of Travel Counselling Pages 41 and 42 .

Pan Am Building Tariff Skills, Unit I, Lesson 6; and Unit 2, Lesson 7 .

INSTRUCTOR'S NOTES :

Read (iv) Basic Fare Construction, Page 41 and 42 .

Complete Lesson 6, What's Your Destination? Unit I, Pan Am Building Tariff Skills.

Complete Lesson 7, Information Please, Unit 2, Pan Am Building Tariff Skills.

\section{ASSIGNMENT}

Lesson 7

1. What are the three principles used to construct a fare when there is no through-fare? Give an explanation of each.

2. The turnaround point on a return trip is referred to by several names, give two:

a)

b)

3. How do you determine the turnaround point in a multi-stop itinerary? 
4. Draw geographical diagrams for the following itineraries:
a) Toronto - San Fransisco
b) Montreal, Toronto, Vancouver, Honolulu, Tokyo
c) Montreal, Gander, Copenhagen, Helsinki, London, Montreal.

d) Rome, Istanbul, Tehran, Syaney, Hong Kong, Moscow, Rome.

e) Toronto, Bermuda, Antigua, Port of Spain, Caracas, Lima, Santiago, Buenos Aires, Sao Paulo, Brazilia, Belem,
New York, Toronto.

5. Using the Table of Contents, Page 8, Lesson 7, Unit 2 of Pan Am Building Tariff Skills, on what page would you look to answer the following client questions:
a) My baby is 18 months, are there special fares?
b) Can I take my cat with me to London?
c) If I am travelling with a group of 12 can we pool our luggage?
d) How long is my return ticket to London valid?
e) Can we send our nine year old to London?

5. Answer the following questions about general rules:

a) If a salesman has a ticket from Vancouver to Tokyo but is ill, can the company send a substitute salesman on the same ticket?

b) What is the first class baggage allowance Rome to London?

c) If the fare from Toronto to Buenos Aires is $\$ 552.00$ CAD first class and $\$ 385.00$ CAD economy class what 
would the excess baggage cost per kilo be for:

i) First Class?

ii) Economy Class?

d) When does a ticket expire, and what can be done with an expired ticket? 
TOPIC: $\quad$ Reading the Air Tariff III

OBJECTIVES: The student will be able to locate answers to general passenger inquiries, locate and apply tariff definitions and apply rules for "stopover" and "transit" to a passenger's itinerary.

REFERENCES: Pan Am Building Tariff Skills, Unit 2, Lessons 8 and 9 .

INSTRUCTOR'S NOTES:

Complete Lesson 8 , What in the World? Unit 2 Pan Am Building Tariff Skills.

Complete Lesson 9, Tips on Side Trips, Unit 2 Pan Am Building Tariff Skills.

\section{ASSIGNMENT}

Lesson 8

1. Which book of the Air Tariff contains a list of definitions?

2. Give the city and country for the following city codes classifying them according to: Europe, Middle East, Africa, U.S.A., Continental U.S.A., North America, North/ Central Pacific and South Pacific. Note: A code may have more than one classification:

$\begin{array}{lll}\text { CITY CODE } & \text { CITY COUNTRY } & \\ \text { AKL } & \\ \text { ACA } & \\ \text { BDA } & \\ \text { FAI } & \end{array}$


NBO

CAI

AMM

OSL

NIC

MOW

ALG

BOS

YYZ

JKT

3. Give two examples of the following, drawing a route map, and indicating point of origin, destination, or turnaround point.
a) One way trip.
b) Open Jaw.

4. On International flights, what is the difference between a stop-over and a transit? 
LESSON : Nine

TOPIC: $\quad$ Reading the Air Tariff III

OBJECTIVES: The student will be able to calculate seasonal and special fares; locate and interpret the excursion fare rules; calculate minimum and maximum stays for excursion fares and compute a fare for an accompanied child or infant.

REFERENCES: Pan Am Building Tariff Skills, Unit 3. Lesson 10 and 11 .

INSTRUCTOR'S NOTES :

Complete Tuesson 10, Bargain Hunting, Unit 3, Pan Am Building Tariff Skills.

Complete Lesson 11, Tariff for Tots, Unit 3, Pan Am Building Tariff Skills.

\section{ASS IGNMENT}

Lesson 9

1. Draw a reference seasonal fare chart for Eastbound and Westbound Transatlantic travel.

a) Westbound

b) Eastbound

2. Using the charts, indicate which fare will be applicable YH, YO, YL? Give the city codes for each:

\begin{tabular}{|c|c|c|c|}
\hline FROM & TO & DATE & APPLICABLE FARE \\
\hline Toronto & London & March 22 & \\
\hline Montreal & Paris & July 3 & \\
\hline Ankara & Chicago & October 28 & \\
\hline
\end{tabular}




\begin{tabular}{|c|c|c|c|}
\hline FROM & $\underline{\text { TO }}$ & DATE & APPLICABLE \\
\hline Miami_ & Munich & October 21 & \\
\hline Beirut_ & Montivideo & June 5 & \\
\hline Lagos_ & Rio de Jan & April 18 & \\
\hline Lima & Lisbon & January 10 & \\
\hline Washington & Brazilia & February 16 & \\
\hline Seattle & Madrid & September 30 & \\
\hline
\end{tabular}

3. How do you calculate the fare on a return trip ticket if return trip is a different applicable rate?

4. What are two features of an excursion fare?

5. When a numbered paragraph is missing in the blue pages of the Air Tariff, what can be assumed?

6. Compute the minimum stay and expiration dates for the following excursion fares:

a) YE28 - minimum stay 14 days. Travel begins July 4 th.

i)

ii)

b) YE45 - minimum stay 22 days. Travel begins: February 23 .

i)

ii)

c) YE21 - Minimum stay 14 days. Travel begins: December 26

i)

ii)

d) YE30 - Minimum stay 10 days. Travel Begins: August 4

i)

ii) 
e) YE45 - Minimum stay 22 days. Travel Begins: November 13 i)

ii)

7. Calculate the fares for the following accompanied children:

$\begin{array}{lclll}\text { NAME } & \text { AGE } & \text { FLIGHT } & \text { ADULT FARE } & \text { FARE CHARGED } \\ \text { Liza } & 2 & \text { LAX - NYC } & \text { FCU 180.00 } & \\ \text { Ron } & 12 & \text { YYZ - LON } & \text { FCU 256.00 } & \\ \text { George } & 13 & \text { TYO - RIO } & \text { FCU } 844.00 & \\ \text { Elsa } & 16 & \text { YUL - WAN } & \text { FCU 310.00 } & \\ \text { Ted } & 28 \mathrm{mo} . & \text { YVR - FDF } & \text { FCU } 425.00 & \\ \text { Myra } & 11 & \text { MIA }- \text { TIJ } & \text { FCU 210.00 } & \\ \text { Bono } & 5 & \text { JNB - ACC } & \text { FCU 308.00 } & \\ \text { Fred } & 24 \mathrm{mo} . & \text { KIN }- \text { DEN } & \text { FCU 328.00 } & \\ \text { Arthur } & 8 \mathrm{mo} . & \text { MSP - AMS } & \text { FCU 318.00 } & \\ \text { Sally } & 22 \mathrm{mo} . & \text { BRU - BSB } & \text { FCU 628.00 } & \end{array}$


LESSON : $\quad$ Ten

TOPIC: Reading the Air Tariff V. Mileage System, Fare Construction Units.

OBJECTIVES: The student will be able to apply techniques of good itinerary management, work out mileage problems in a step by step manner, and use the Fare Box for fare calculation using the Fare Construction Units.

REFERENCES: Principles and Procedures of Travel Counselling Page 42 to 64 .

Pan Am Building Tariff Skills, Unit 4, Lessons 12,13 and 14 .

INSTRUCTOR'S NOTES :

Read Mileage Systems, Principles and Procedures of Travel Counselling page 42 to 47 .

Complete Lesson 12, How Many Miles, Unit 4, Pan Am Building Tariff Skills.

Complete Lesson 13, Ideal Itineraries, Unit 4, Pan Am Building Tariff Skills.

Complete Lesson 14, Test Your Tariff Skills, Unit 4, Pan Am Building Tariff Skills.

Read V, Principles and Procedures of Travel Counselling Fare Construction Units, Pages 47,48 and 65.

\section{ASSIGNMENT}

Lesson 10 .

1. Explain the mileage system in your own words. 
2. Using the non-stop sector mileage pages, 56 to 61 , in Principles and Procedures of Travel Counselling, give the actual number of miles a person would fly between:
a) Rome to Lisbon
b) New York to Rio de Janeiro
c) Ottawa to San Francisco
d) Madrid to Montreal
e) London to Montego Bay
f) $\mathrm{ACC}$ to $\mathrm{MAD}$
g) LIS to MIL
h) YYZ to MEX
i) $\mathrm{CCA}$ to RIO
j) TIP to $\mathrm{ZRH}$

3. In which book of the Air Tariff would you find the following:
a) Maximum Permitted Mileages
b) Non-stop Sector Mileages
c) General Rules
d) Fares between IATA Areas $2 \& 3$
e) Transatlantic Fares

4. List the ten methodical steps in using the mileage system.

5. Name the three methods which can be used to maximize an airline's revenue from a ticket?

6. Submit your progress chart from the Pan Am Building Tariff Skills. 
LESSON :

Eleven

TOPIC :

Air Traffic Conference of America (ATC)

Reading the Domestic Tariffs

OBJECTIVES: The student will be able to use the six volumes of the Squire's Tariff in preparing itineraries and quoting fares for domestic air travel.

REFERENCES: Principles and Procedures of Travel Counselling Pages 65 to 103 .

Air Canada, It Will Help If You Know, pages 77 to 84

INSTRUCTOR'S 'NOTES :

Read Principles and Procedures of Travel Counselling, pages 65 to 103

\section{ASSIGNMENT}

Lesson 11

1. ATC is the abbreviation for what organization?

2. Domestic air travel is defined as air traffic performed:
a)
b)
c)

3. IATA and the ATC have powers which extend over areas in common and some which are not in International and Domestic Air traffic. List as many as possible indicating whether they are controlled by the IATA and ATC.

Sample:

IATA ,

ATC

International Routes

$\mathrm{X}$ 
4. The Airline Tariff Publishing Company, Inc., produces the only official airline tariff for domestic air travel. What is it called in the travel trade and why?

5. How does a Travel Agent obtain his own copy of the Squire's Tariff?

6. Why is it important that the Squire's Tariff is kept up to date?

7. Which volume of Squire's is referred to as the Rules Tariff and list the seven major headings.

8. Explain the difference between the fares in Volume 2 and Volume 3 of Squire's Tariff.

9. In what volume of Squire's would you find the routing for YYZ to MCI?

10. Would a Canadian Travel Agent be required to use Volume 5 and 6 in the course of his/her work? If so, under what circumstances? 
LESSON : $\quad$ Twelve

TOPIC: Airline Terms and Definitions

OBJECTIVE: The student will be able to use the technical

terms used in the travel industry related to airlines and their operations.

REFERENCES: Principles and Procedures of Travel Counselling Page 103 to 106 .

Air Canada, It Will Help If You Know, Page 97 to 107 .

INSTRUCTOR'S NOTES :

Read 5, Glossary of Airline Terms page 103 to 106 in Principles and Procedures of Travel Counselling.

In addition to the terms in Principles and Procedures of Travel Counselling, there are abbreviations and terms which you may encounter in your work and need the correct definitions. Read Glossary of terms: Air Canada, It Will Help If You know, page 97 to 107 .

\section{ASSIGNMENT}

Lesson 12

1. What is an Add-On Fare? And give four other names for an Add-On Fare.

2. What would be the gateway city if flying:
a) Winnipeg to Vienna?
b) Calgary to Tokyo?
c) San Fransisco to Sydney?
d) Denver to London? 
e) YHZ to BRU?

f) SEA to FRA?

g) YQG to BGI?

h) YYZ to ZRH?

i) YUL to $\mathrm{ATH}$ ?

j) YUL to HNL?

3. If a woman is travelling YYZ to YVR Y-OW \$157.0n, what would be the fare?

4. If the fare YYZ to YVR is 157.00 , what would be the fare for :

a) A woman

b) A woman and her husband

c) A woman and a 3 mo. child

d) A woman and twins age $14 \mathrm{mo}$.

e) A woman, her husband and twins age $14 \mathrm{mo}$.

f) A woman and a child 10 years.

g) A woman and 12 year old son

h) A woman, her husband, twins of 14 mo. and a loyr. old

i) A woman, her husband, 3 mo. infant, twins $14 \mathrm{mo}$. , a 10 year old and a 14 year old.

5. Calculate the fare for (a) to (i) above for a Montreal to Geneva Y-RT \$571.00. 
6. Are the following True or False?

a) Excursion fares are always one way..... TRIJE FALSE

b) The child's fare on international

flights is calculated from gateway

city.................... TRUE FALSE

c) Children's fares differ between U.S.

and Canadian Airlines............ TRUE FALSE

d) An adult fare is charged for anyone

over 12 years of age............ TRUE FALSE

e) Excursion fares always have restricted

days of travel.............. TRUE FALSE

f) Only a male person qualifies as the

head of a family on the family plan... TRUE FALSE

g) Stop-overs are permitted on joint

fares.................. TRUE FALSE

h) Local fare applies to the routes of a

single carrier............... TRUE FALSE

i) A Through Fare is always less expensive

than a joint fare............. TRUE FALSE

j) $F$ is the code letter for first class

and allows $44 \mathrm{lb}$. baggage allowance. TRUE FALSE

7. What is the U.S. and European name for Economy - Y?

8. Which of the following are promotional fares; give a definition of the promotional fares only.
a) $\mathrm{F}-\mathrm{OW}$
b) IIT
c) $\mathrm{CBIT}$ 
d) $\quad Y-R T$

e) APEX

f) GIT

9. Explain what you understand to be the difference between a Joint Fare and a Through Fare.

10. There are several types of journeys by air, identify the following: RT, OW, CT, OJ.
a) Toronto-Montreal-Toronto
b) Thunder Bay-Toronto- Montreal
c) Toronto-Montreal-Miami-Los Angeles-

Vancouver-Toronto
d) YYZ - YVR - TYO
e) YYZ - LON - PAR - NYC
f) PAR - LON - MAD - ROM - PAR
g) ROM - MAD - LON
h) YYZ - BGI - POS - MIA - YUL
i) $\mathrm{YMX}$ - YVR - HKG - TEH - LON - YMX

11. What is the definition for:
a) Stop-over (International)
b) Stop-Over (Domestic)
C) Connection (International)
d) Open Ticket
e) Connection (Domestic)
f) No Show
g) Gateway 
LESSON : Thirteen

TOPIC: The 24 Hour Clock System; Computing Time, Flying and Elapsed.

OBJECTIVE: The student will be able to convert $A M / P M$ to the 24 hour clock system and vice versa, know the relationship of the North American Time Zones to Greenwich Mean Time and be able to calculate the Elapsed Time.

REFERENCE: Principles and Procedures of Travel Counselling Pages 106 and 107

Air Canada, It Will Help If You Know

INSTRUCTOR'S NOTES :

Read Section 6, Page 106. The 24 Hour Clock System:

The travel counsellor should become very proficient at convert to and from the 24 hour clock system.

Read and complete the following:

Air Canada, It Will Help If You Know, page 37 to 42 .

Section 7, Principles and Procedures of Travel Counselling pages 106 and 107, Computing Time, Flying and Elapsed

In order that you are able to compute the flying and elapsed time effectively, read and complete the following:

Air Canada, It Will Help If You Know, pages 43 to 46 .

\section{ASS IGNMENT}

LESSON 13

1. a) How many time zones are there in Canada?

b) Name each. 
c) Give the abbreviation for each and the relationship to Greenwich Mean Time.

2. Give the formula for calculating the elapsed time:
a) Travelling East to West.
b) Travelling West to East.

3. Complete the applicable 24 hour clock or AM/PM times:

\begin{tabular}{|c|c|c|}
\hline & $\mathrm{AM} / \mathrm{PM}$ & 24 HOUF \\
\hline 1. & $11: 25$ AM & \\
\hline 2 & $12: 00$ Noon & \\
\hline 3. & $4: 55$ AM & \\
\hline 4 & $4: 55 \mathrm{PM}$ & \\
\hline 5 . & $10: 30 \mathrm{PM}$ & \\
\hline 6 & $3: 00 \quad \mathrm{PM}$ & \\
\hline 7 . & $8: 05 \mathrm{AM}$ & \\
\hline 8 . & & 1930 \\
\hline 9. & & 1533 \\
\hline 10 & . & 0920 \\
\hline 11. & . & 2320 \\
\hline 12 . & & 2355 \\
\hline 13. & & 0210 \\
\hline 14 & & 0045 \\
\hline 15. & $2: 30, A M$ & \\
\hline 16. & $12: 30 \quad P M$ & \\
\hline 17. & - & 0100 \\
\hline 18 & $4: 21$ AM & \\
\hline 19. & 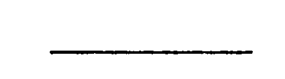 & 0633 \\
\hline 20 & $8: 44 \quad \mathrm{PM}$ & \\
\hline
\end{tabular}


4. Complete the blanks in the following questions. Reference can be made to a time zone chart.

$\begin{array}{llllll}\text { TIME } & \text { LOCATION } & \text { ZONE } & \text { TIME } & \text { LOCATION } & \text { ZONE } \\ 1250 & \text { Toronto } & \text { EST } & 1150 & \text { Winnipeg } & \text { CST }\end{array}$

1. 2030. Cleveland EST _ Frankfurt GMT+1

2. 0330 Kingston EST Saskatoon

3. 1040 Regina __ _ B B _ _ GMssels

4. 1325 Copenhagen. GMT+1_ Montreal _

5. — YYZ ETS 0445 CHI

6. 0145 St. John's NDT _ Toronto EDT

7. 1045 Edmonton Winnipeg

8. ㄴ MIA _ $\quad 1325$ YUL

9. $—$ YVR PDT 0825 YYZ

10. - PAR GMT+1 2305 . CHI

11. NAS — $\quad 0530 \quad$ YYZ

12. 1110 LAX

YHZ

ADT

13. 2210 YMX

$-\quad-\quad \mathrm{YHZ}$

VIE

14. 0759 POS

EDT

EDT _ YYZ

15. 1845 YWG

YYT 
5. Calculate the following Elapse Time:

a) Air Canada Flight 136 leaves Vancouver at 9:15 AM and arrives Toronto 4:25 PM non-stop.

b) CP Air Flight 64 leaves Toronto at 3:30 PM and arrives in Montreal at 4:35 PM non-stop.

c) AST BDA to EST YUL

1:40PM 3:15PM L AC $955 \mathrm{~F} / \mathrm{Y}$ D9S S 3

d) EST YUL to MST YYC

11:40 AM L 4:40 :M AC $135 \mathrm{~F} / \mathrm{Y}$ D9S S 3

e) EST NYC to CST YWG

$11: 50$ AM L $3: 24$ PM NW $215 \mathrm{~F} / \mathrm{Y} 727 \mathrm{~L} 1$ 
LESSON : $\quad$ Fourteen

TOPIC: $\quad$ Flight Reservations, Computer Reservation Systems

OBJECTIVES: The student will be able to make flight reservations

REFERENCES: Principles and Procedures of Travel Counselling

Pages 107 to 110

Air Canada Reservation System, It Will Help If

You Know, pages 15 to 18 .

INSTRUCTOR'S NOTES :

Read Section 8, How To Make Flight Reservations, Principles and Procedures of Travel Counselling, page 107

Read Section 9, Computer Reservation Systems, Principles and Procedures of Travel Counselling, page 107 to 110

Read Air Canada Reservations System, pages 15 to 18, It Will Help If You Know.

\section{ASSIGNMENT}

LESSON 14

1. When are major changes in airline schedules make?

2. What are the major advantages of computer reservation systems over a manual system?

3. List the information you must give to the airline, in the correct order, when booking a flight.

4. Make a booking for yourself YYZ - LON return. Choose your own dates and other information. Write a transcript of the call the agent would place to the airline to book the flight. 
LESSON: $\quad$ Fifteen

TOPIC: $\quad$ Ticketing I

OBJECTIVE: The student will be able to fill in the name and reservation data on adults' and infants' tickets; determine the issuing carrier, issuing office and number of flight coupons from the ticket number; describe the make up of a ticket and state the purpose and distribution of the coupons; write an acceptable ticket and void a ticket.

REFERENCES: Principles and Procedures of Travel Counselling Page 110 to 114 .

Pan Am Basic Instructions for Writing a Ticket, Study Guide and Unit 1.

INSTRUCTOR'S NOTES :

Read Section 10, Ticketing, Principles and Procedures of Travel Counselling, page 110 to 114 .

i) Parts of an Airline Ticket

ii) General Rules for Issuing Tickets

iii) Ticket Completion

1. Date and Place of Issue

2. Name of Passenger

3. From/To (passenger's itinerary)

4. Reservation Data

Read pages 2 and 3 of the STudy Guide Basic Instructions for Writing a Ticket

Read and Complete Unit 1, Basic Instructions for Writing a Ticket. Complete Test page 4 to 6 , STudy Guide. 
LESSON 15

1. What are the names of two ticketing handbooks which will give a travel agent all the necessary ticketing information?

2. Where will you find the "Conditions of Contract" on an airline ticket?

3. How many digits are there in the ticket number?

Is this true for all IATA tickets for all airlines?

4. GAO is the abbreviation for:

5. Answer True or False:
a) Never destroy a ticket
b) There are 4 coupons in all IATA tickets
c) A ball point pen should always be used to write tickets.
d) You can cross out minor errors on a ticket
e) A ticket can be made out in more than one name.

f) Hyphenated names are written as two names

6. Explain how you would void a ticket.

7. Where will you find the two letter Airline code if you are not sure?

8. If an error is made on a ticket, it could cause problems for:

9. When an open ticket is made, the carrier 2 letter code can only be omitted for what reason?

10. If you were teaching a new employee in a travel agency to write tickets, explain the steps you would show the new employee and the rules he should follow. 
11. Write the first digits of:
a) A 2-flight coupon ticket issued by Air CAnada
b) A 3-flight coupon ticket issued by CP Air
C) A 2-flight coupon Pan Am ticket issued by a Travel Agent.

d) A 4-flightcoupon Air CAnada ticket issued by a Travel Agent.

e) A 4-flight coupon CP Air Ticket issued by a Travel Agent.

12. Submit you ticket from Study Guide Test for Unit 1 plus your results of the test. 
TOPIC: $\quad$ Ticketing II

OBJECTIVES: The student will be able to fill the Fare, Payment and validity portions of the ticket.

REFERENCES: Principles and Procedures of Travel Counselling, Page 144

Pan Am Basic Instructions for Writing A Ticket, Study Guide and Unit II.

Air Canada, It Will Help If You Know, page 71 to 76 and 85 to 96 .

INSTRUCTOR'S NOTES :

Read Section 10, Ticketing page 114 to 116 .

5. Fare Basis

6. Ticket Designator

7. Tour Codes

8. "Not Valid Before"

9. "Not Valid After"

10. Allow

Read Air Canada, It Will Help If You Know, Baggage, page 71 to 76 .

Read Section 10, Ticketing page 116.

11. Origin and Destination

12. Conjunction Ticket(s)

13. Restrictions and endorsement

14. Form of Payment

15. Fare Calculation

16. Comm. Code 
18. Equivalent Amount Paid

19. Tax

20. Total

Read and complete, Unit II, Basic Instructions for Writing a Ticket

Complete Test page 7 and 8 , Study Guide

Read and complete Air Canada, It Will Help If You know, Ticketing, page 85 to 96 .

You will note during the Air Canada exercises that there are differences beween the IATA ticketing method and those used on Domestic flights.

\section{ASSIGNMENT}

LESSON 16

1. When completing the "Fare Basis":
a) Primary codes Indicate:
b) Secondary codes indicate:
c) Discount Codes indicate:

2. What do the following Fare Basis Codes mean?
a) YLQE28
b) $\mathrm{FH}$
c) YNE1M
d) $\mathrm{FE} 30$
e) YLE 45

3. Cash has several equivalents, name four:
a)
b)
c)
d) 
4. What are conjunction tickets?

5. At what time do you validate a ticket?

6. Name six items which can be carried aboard an aircraft but are not included in the baggage allowance.

7. What would be the free baggage allowance for the following:
a) YYZ - NYC YE21
b) YUL - LON FOW
c) YVR - YYT FRT
d) $Y Y Z$ - BUE YOW

8. What is meant by the pooling of baggage?

9. A passenger with an economy ticket checks in at Montreal with 35 kilograms of baggage for travel to Caracas, Venezuela and the first class fare is $\$ 580.00$, calculate the excess baggage charge.

10. A family flying YYZ to ZHR Economy consisting of husband, wife and three children, 12, 9, and 18 months would like to know their total baggage allowance.

If they flew first class what would be their total allowance?

11. What body governs the commissions paid for the following?
a) YYT - MSP
b) $\mathrm{MEX}-\mathrm{CCS}$
c) YYZ - YVR
d) LON - SYD
e) MOW - YUL 
TOPIC:

Miscellaneous Charges Order (M.C.O.) and Airline Tour Order

OBJECTIVE: The student will be able to complete Miscellaneous Charges Orders and Airline Tour Orders.

REFERENCES: Principles and Procedures of Travel Counselling Pages 118 to 120 .

INSTRUCTOR'S NOTES :

Read pages 118 to 120 in Principles and Procedures of Travel Counselling:
iv) Miscellaneous Charges order (M.C.O.)
v) Airline Tour Order

\section{ASSIGNMENT}

\section{LESSON 17}

1. What is the most common reason that a travel agent will issue an M.C.O.?

2. Explain to a new employee the step by step completion of an M.C.O. for a P.T.A. Refer to the various sections of the M.C.O. by the correct names. (see page 119 Principles and Procedures of Travel Counselling)

3. If a married couple with two children aged 18 and 12 were taking an ATC approved tour, how many Tour order forms would you complete?

4. If you were a travel agent in Brampton, Ontario and issued an M.C.O. for a P.T.A.: LON - YYZ, YH,, who would issue the ticket? 
TOPIC: Charter Services, Taxes on Air Transportation, Credit Card Sales, Airline Equipment and Reference Materials.

OBJECTIVES: The student will be able to sell Advance Booking Charters, calculate air trasportation taz, handle credit card sales and recognize airline equipment.

REFERENCES: Principles and Procedures of Travel Counselling Pages 119 to 131 .

Air Canada, It will Help If You Know. Air Canada Fleet pages 19 to 26 .

INSTRUCTOR'S NOTES :

Read Principles and Procedures of Travel Counselling, page 119 to 121 .

Read Air Canada Fleet, It Will Help If You Know, Pages 19 to 26 .

\section{ASSIGNMENT}

LESSON 18

1. What are Advanced Booking Charters?

2. What are the restrictions and limitations placed on $A B C^{\prime} S$ ?

3. What are the main differences between $A B C$ flights and scheduled flights?

4. What is the Canadian Air Transport Tax?

5. Calculate the tax on the following Canadian air fares.
a) $\$ 85.00$
b) $\$ 180.00$ 

c) $\$ 35.00$
d) $\$ 50.00$
e) $\$ 210.00$

6. Using the OAG, state what credit cards are accepted by the following airlines.
a) Air Canada
b) CP Air
c) Pan Am
d) British Airways
e) Air France
E) Trans Air

7. What reference books would you expect to find in a travel agency dealing with Airline Tariffs, Fares and Ticketing?

8. What is the seating capacity of:
a) Boeing 747
b) L1011

F

Y

$\mathrm{F}$

Y

9. What is the normal cruising speed of:
a) Boeing 747
b) L1011
c) DC9

10. What is the title of the crew member in charge of in-flight service on the Boeing 747 ?

11. How many decks has a Boeing 747 ? 
1. Determine the correct fare to be charged between Toronto and Palermo, $Y$ class, using the Air Tariff sample transAtlantic page in the CITC textbook (figure 20).

You are required to complete the fare calculation box accompanying this sheet; also you must show the method you Used to calculate the fare. Be certain your figures are clear and legible and that all totals are correct. Routesheets, flight numbers and ticketing are not required. OAG-International should be used to determine sector miles. May 16,1975 YYz-SNN via AC nonstop May 19 SNN-LON via BE nonstop with immediate connection LON-STO via SK nonstop May 21 STO-CPH via SK

with immediate connection

CPH-ROM via AZ nonstop with immediate connection

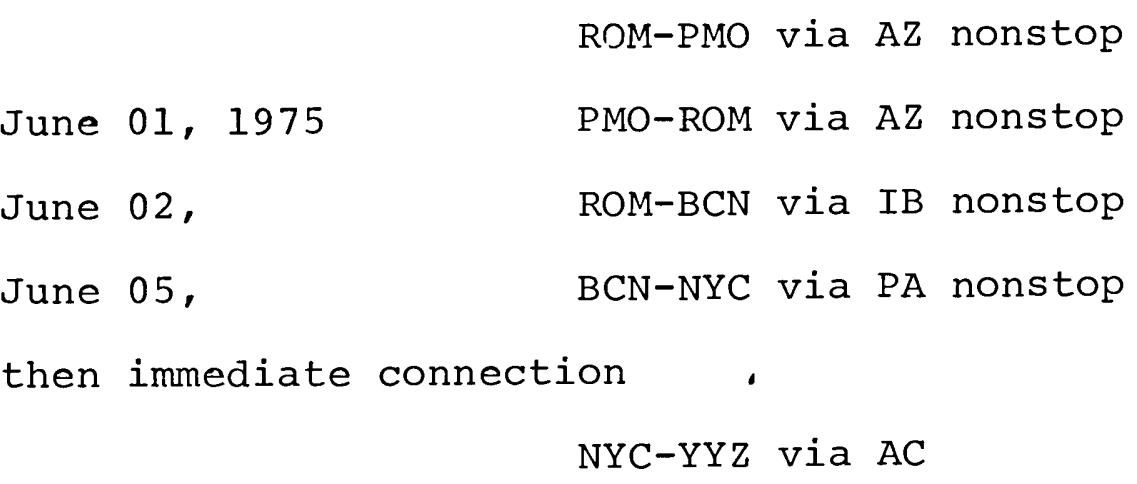


2. CHILDREN'S FARES

Specify the percentage or fractional discount which would apply in the following airfare transactions. Assume that a full-fare paying passenger accompanies the child in all cases: (Actual fares are not required)

i) Child 9 years old APEX from Canada

ii) Child 11 years old YLE21 to Greece from Ottawa

iii) Child 11 years old YHE21 to Ottawa from Greece iv) Child 15 months old YYZ-LON

v) Child 20 months old YYZ-TYP

vi) 6 year old YYZ-MBJ

vii) 6 month old YYZ-BGI

viii) loyear old YYZ-LON via $A B C$

ix) 9 year old YVR-YHZ

3. Specify the type of air fare most likely to be sold in the following cases, showing "fare-basis" ticketing codes where possible. (Actual fare-prices not required.)

i) YYC to YYZ Y Class

OW stand-by basis for a 19-year old student

ii) $\mathrm{YZZ}$ to $\mathrm{YXE} \mathrm{Y}$ Class

OW for a 19-year old student on a confirmedreservation basis.

iii) One-week London Show Tour Y Class

iv) The Two-Week London Show Tour Y Class

v) YYZ-MBJ-YYZ Y Class; 127day holiday in December. No prepaid land arrangement. 
vi) YUL-AUA-YUL Y Class; during June for two weeks withprepaid American Express Tour land arrangements.

vii) On May lst, pax books and purchases Y class ticket via scheduled flights to PAR commencing from YWG on July 20; 4-week stay then return home YWG.

viii) F Class YVR to SYD, return by ship to YVR.

ix) YYZ-ACA-YYZ 19 day stay Y class.

X) YYZ to MEX Y Class June 01, returning MEX to YYZ Y Class June 03.

4. Specify the percentage or fractional discount which would apply on the following air transportation for children. Assume that a full-fare paying passenger accompanies the child in all cases. (Actual fares are not needed.)

i) YOW-YWG 14 month old Y Class

ii) NYC-SEA, 12 year old F Class

iii) APEX Fare Toronto-Vienna 9 year old

iv) Child 11 years YLE 21 to ATH from YYZ

v) 6 month old infant, Toronto-Barbados.

vi) 9 year old Montreal to YVR 10/30-day excursion (fare basis: YE32)

vii) 7 year old Nassau-Montreal Y Class

viii) 7 month old Nassau-Montreal F Class

ix) YHE45 Toronto-Paris, 14 month old

x) 11 Year old YYZ-LON winter GIT 
5. Mr. K. Donovan holds the following reservations which he made through your office:

March 15/76 AC 806Y YYZ-SNN 2030/0850+1 Min Apr.06 April 27/76 CP 223Y LIS-YYZ 1150/1800 Max Apr.29

He will travel within Europe by surface transportation, but he asks you to make a flight reservation for one journey in Europe, and you make the following reservation:

AF981Y 09 April CDG-MAD 1130/1310

Upon checking the Air Tariff you find the following information to determine the fare to be charged:

$$
\begin{aligned}
& \text { YYZ-SNN } \text { YLE45 CAD } 330.00 \text { or FCU } 312.00 \\
& \text { YUL-SNN } \text { YLE45 CAD } 306.00 \text { or FCU } 288.00 \\
& \text { PAR(CDG) MAD Y FFR } 567.00 \text { or FCU } 113.90 \\
& \text { YUL-LIS YLE45 CAD } 315.00 \text { or FCU } 297.00 \\
& \text { YYZ-LIS YLE45 CAD } 339.00 \text { or FCU } 321.00 \\
& \text { Devaluation Surcharge } 6 \%
\end{aligned}
$$

i) Determine the applicable fare, showing clearly all your calculations.

ii) Issue the ticket; issue date is March 5/76; form of payment is cash; assume all the above flights are nonstop.

6. i) What do the initials F.C.U. stand for?

ii) Why are F.C.U.'s used:

iii) A passenger purchases a YHE45 ticket between YYZ-PAR using $A C$ in both directions (use trans Atlantic tariff page in your textbook for fare). He also purchases 
Y class round trip PAR-ATH via Olympic Airways. The round trip fare between PAR-ATH is French Francs 1912 or FCU 373.40. Assume the YYZ-YUL add-on fare is 20.00 . Assume also that the pax will be travelling PAR-YYZ on a Saturday. Complete the accompanying Fare calculating ladder in detail.

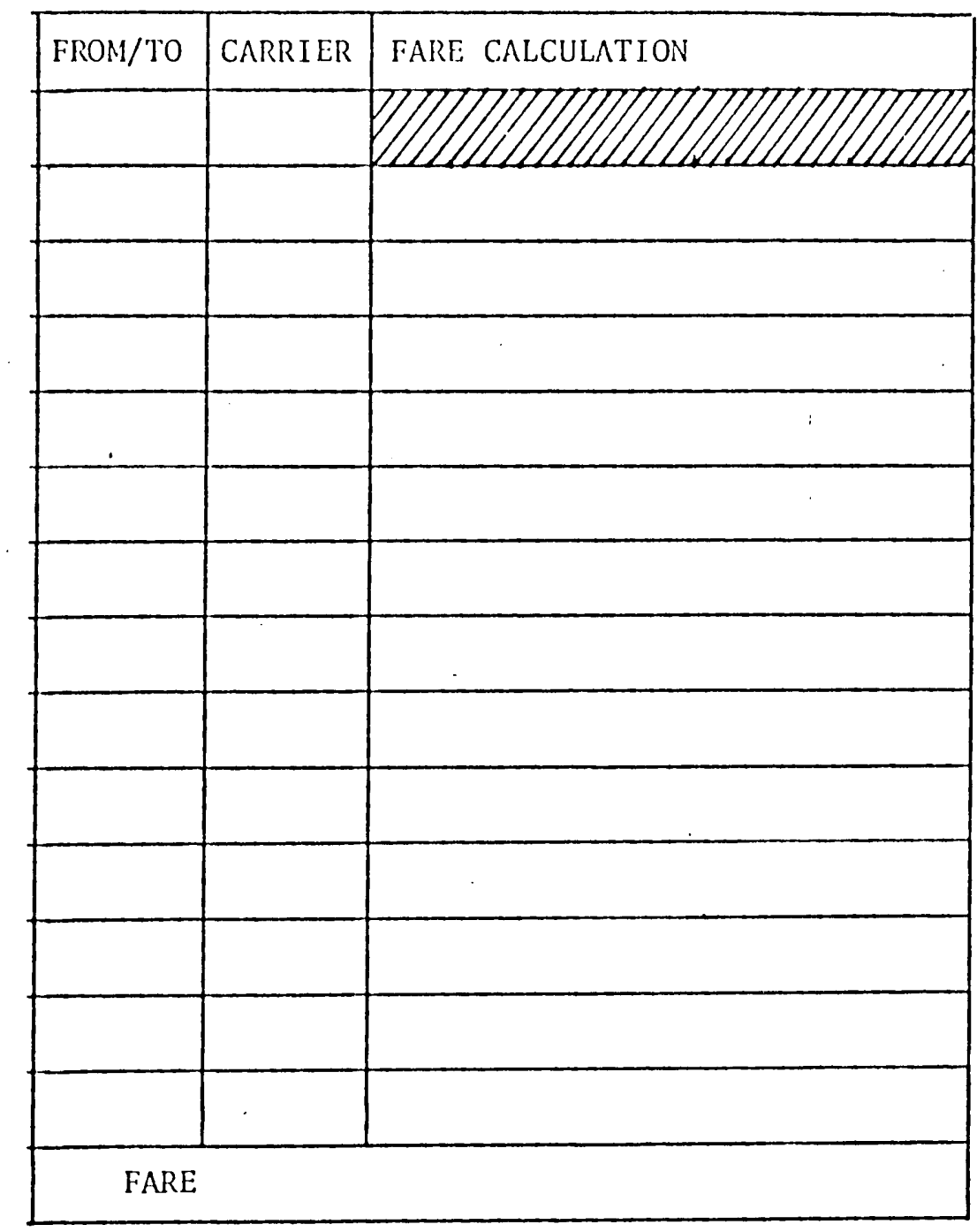


IV UNIT 2: SURFACE TRANSPORTATION AND TOUR PLANNING

In order to complete Unit 2 , the student should have the following :

1. Instructor's Notes

2. Principles and Procedures of Travel Counselling

3. Travel Agents U.S.A. Transportation Guide

\section{Unit 3 Project}

The travel counsellor must have at his finger tips information about all the tours available. This information is not published by any one source although the travel press often summarize the tours that are available. The travel counsellor must, therefore, produce working catalogues of all tours available.

Your project for Unit 3 is to produce an I.T.C. catalogue of all current I.T.C. Programmes operating from your city or nearest departure point.

The information should be filed according to destination.

All information needed when selling an I.T.C. should be available in the catalogue, i.e.-I.T.C. Companies

-Prices

-Days of Operation

-Features of Tours

-Airlines Used

-Accommodation 
-All other Information

Marks will be given for the following:
a) Usefulness as a sales tool
b) Comprehensiveness
c) Accuracy of Information
d) Neatness of Presentation

LESSON: One

TOPIC: Introduction to Ocean Travel

OBJECTIVES: The student will trace the history and background to ocean travel, read modern deck plans and assess a vessel's suitability to the client's needs. REFERENCES: Principles and Procedures of Travel Counselling Page 133 to 137 .

INSTRUCTOR'S NOTES:

Read the Introduction page 133.

Surface transport offers a range of choices with each choice offering distinct advantages. In this section we look at ocean transport. A traveller can use a ship as a vehicle of transport to make a CROSSING between two points such as Dover to Calais. Alternatively he may use the ship as his vacation; accommodation, restaurant, recreation and social centre. In this case he is making a CRUISE. In certain holiday destinations, such as the Greek Islands, the most satisfying mode of travel is to take a cruise. 
Read Section 1:

History and Growth of Cruises. Air/Sea or Fly/Cruise holidays have combined the benefit and popularity of jet travel to the destination (thus saving time reaching the destination) with the romantic appeal of a luxury vacation on board a cruise ship. Passengers are flown to a point such as Athens where they join the cruise ship for a week or two on the sea before they are returned to their departure point, not necessarily the same as their joining port.

Ship design of To summarize, designs usually consist of: Several Decks TOP Deck is reserved for open air use. LOWER Deck is reserved for indoor activity.

REMAINING Decks are reserved for cabins

Cabins are the passenger accommodation at sea.

The student must understand basic nautical terms and the diagram below will assist your memory.

BOW

Front of Ship

Lower Cabin Numbers

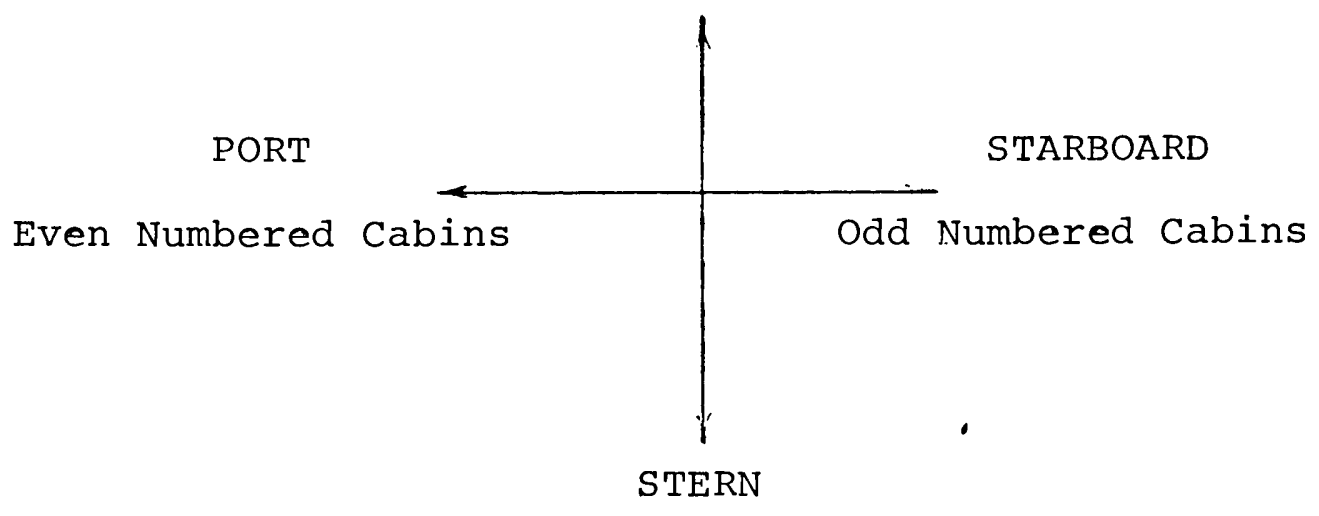

Higher Cabin Numbers 
The student must also be aware that not all cabins have portholes (windows). Most of them do have portholes and are described as Outside Cabins. Those which are totally inside the ship with no portholes are described as Inside Cabins.

\section{ASSIGNMENT}

Lesson 1

1. Which of these features are provided on board the M.S. Boheme: Use the brochure in the Test.
a) Cabins
b) Information Desk
c) Swimming Pool
d) Library
e) Medical Services
f) Purser's Office

2. State whether the following statements are true or false:

a) A cruise ship is basically a vessel used to transport passengers to their destination.
TRUE
FALSE

b) Air-Sea or Fly/Cruise holidays take much longer and are more costly than full cruise vacations.

TRUE

FALSE

c) PORT is the front end of the ship. TRUE

FALSE

d) STARBOARD is the right side of the ship when you are facing the bow.

TRUE

FALSE 
e) Stern is the rear of the ship. TRUE

FALSE

f) BOW is the left side of the ship.

TRUE

FALSE

g) Cabins are usually numbered from Bow to stern is ascending order.

\section{TRUE $\quad$ FALSE}

h) Cabins are odd-numbered on the Port side and even numbered on the starboard side.

$$
\text { TRUE FALSE }
$$

i) A comfortable cruise will allow each passenger 25 GRT and 1 crew member per six passengers. TRUE FALSE

j) All cabins or staterooms have portholes and bathroom facilities.

TRUE

FALSE

3. Which of the diagrams of staterooms on page 136 of the Text show cabins with portholes?

4. Compare ocean travel in the 1920's and 30's with the 1960's and 70 's. Pay special attention to the factors which influenced the growth of ocean travel during these periods.

5. On the map provided, mark the areas, routes and markets of popular cruises.

PRACTICAL ASSIGNMENT'

Study the deck plans on pages 139,140 and 144.

Study the state room (cabin) designs on pages 135,136 and

144. Obtain additional cruise folders and read and interpret their deck plans and cabin designed. 


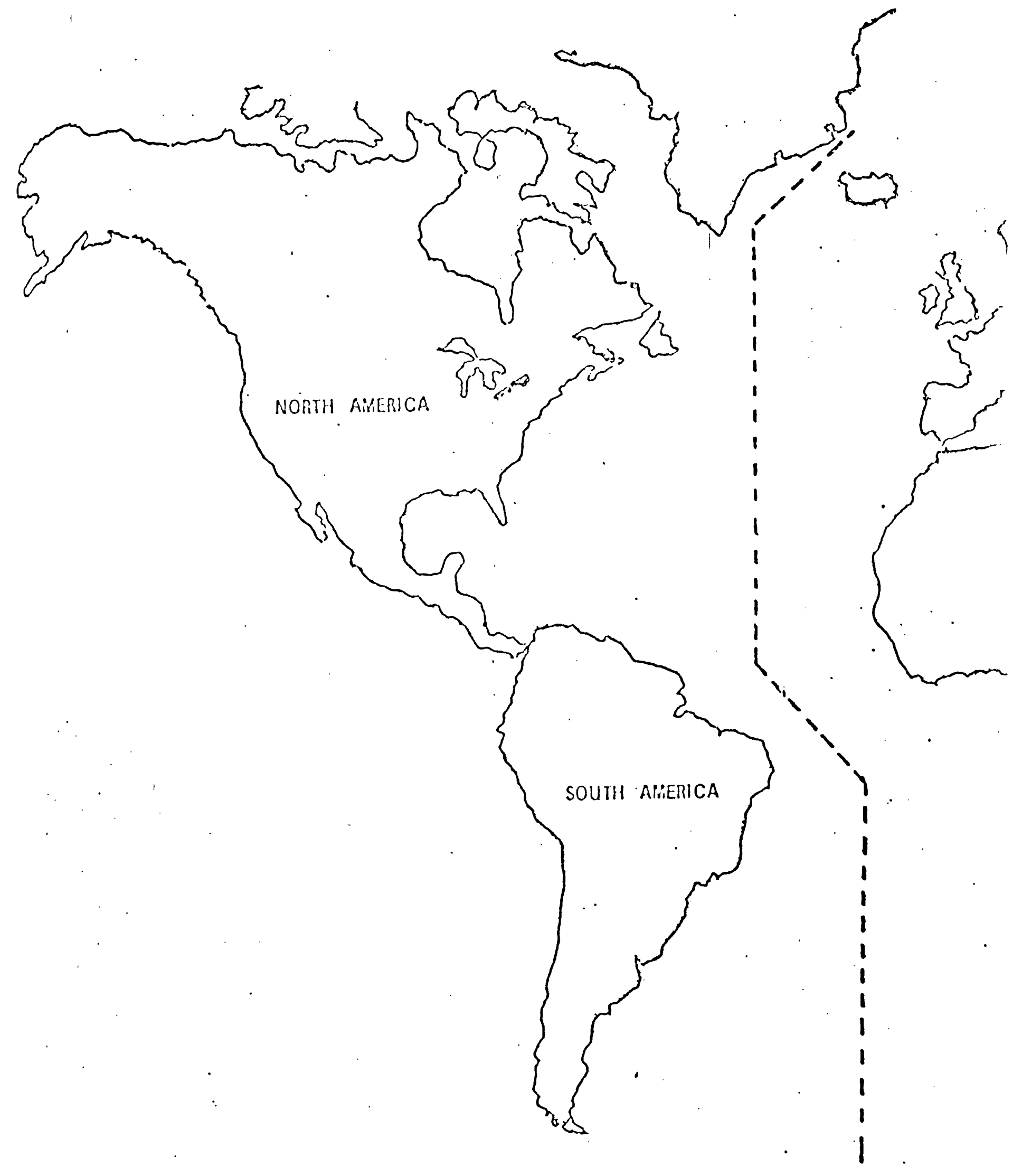




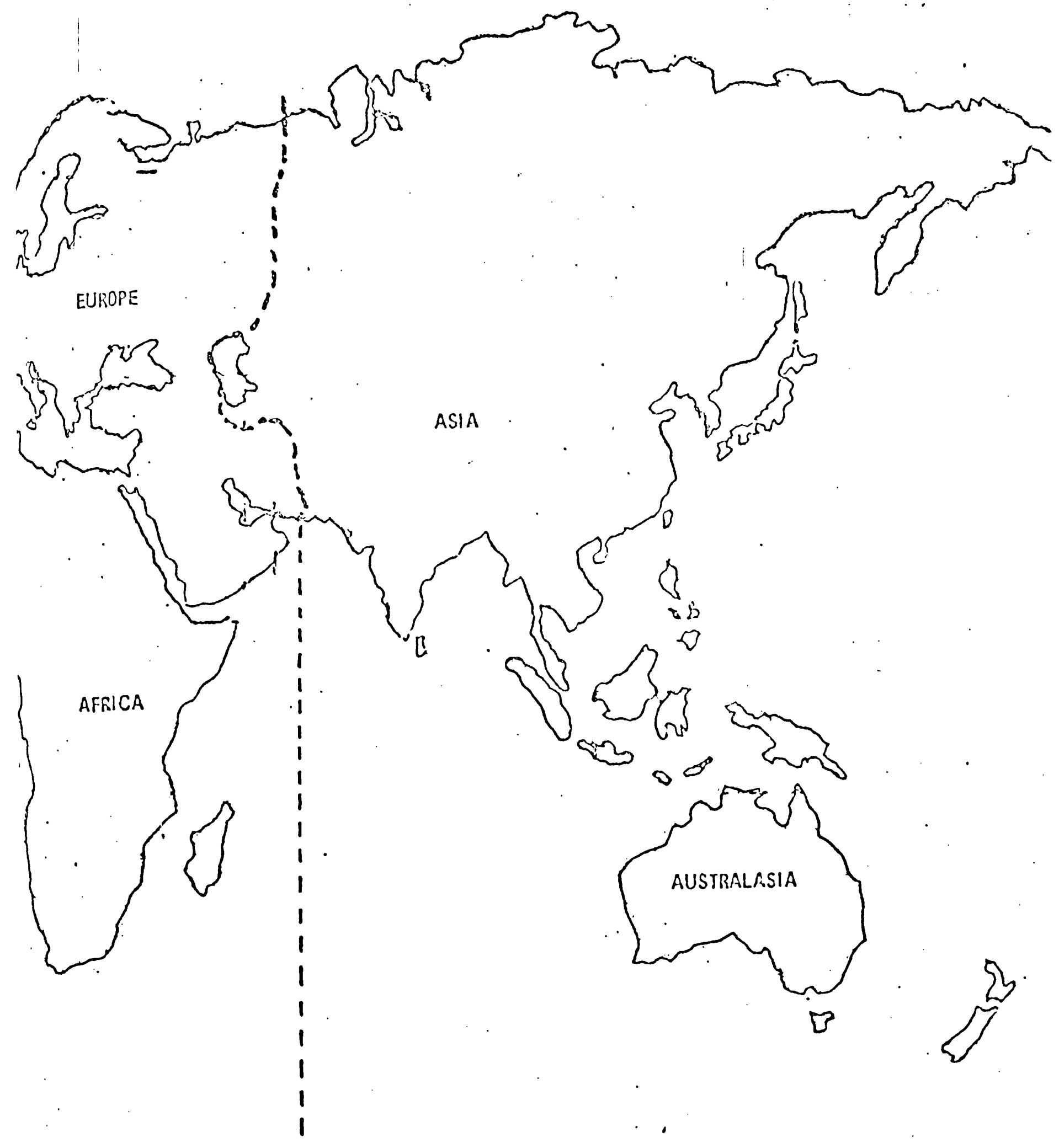


TOPIC: $\quad$ Selling the Cruise

OBJECTIVES: The student will read rate sheets and interpret fares, make reservations and select appropriate cruises for prospective clients.

REFERENCES: Principles and Procedures of Travel Counselling Pages 137 and 138 .

INSTRUCTOR'S NOTES :

Read Section 1 pages 137 and 138.

Fares: The counsellor selling a cruise needs a working knowledge of factors affecting fare prices which may influence the client's choice of cabin. There will be opportuities to sell-up, and it might be easier to achieve with a cruise than with hotel accommodation because cruise prices are inclusive of all meals, entertainment and more.

Reservation Procedures: Deposits MUST be received to obtain a booking. This deposit is accompanied by an application for passenger reservation giving full details of the passenger and the cabin type requested. Late bookings may need fullpayment. When the cabin is allocated, a Passage Contract is issued which gives the terms of the reservation. The client must read it and the counsellor must make sure that everything is understood. As with a hotel booking, the cousellor CANNOT confirm a cabin until it is confirmed by the cruise line.

Guaranteed Accommodation: In some respects the cruise line guarantee of accommodation resembles the airline standby 
list, but it is a firm commitment to the passenger that he will get accommodation. Cancellations and no-shows are invariably going to arise to give room to persons waiting to be accommodated.

Sales Tools: The student must note that there is No single reference manual for cruises like the official Airline Guide. Once the client has specified what type of holiday he is seeking on his cruise, the counsellor can make a selection of brochures which should contain a suitable cruise. The rate sheet for a cruise can be fairly complex and will need to be carefully scrutinized to make sure that the suitable choice is not overlooked.

Further to selecting the cruise and line, the counsellor must advise the client of peculiarities of cabin location which will help him make the right choice. If he is worried a bout getting seasick a cabin near the middle (amidships) would be preferable to one near the bow or stern as these are subject to rise and fall (pitching) in high seas.

older vessels may be subject to vibrations from the engine room, particularly on lower decks. The engine room is low in the ship, therefore the upper decks will have less vibration. Some other features will affect the price of the accommodation, not all have private baths; larger cabins, with several berths, may be shared by an extra party UNLESS the client wishes to pay for the unoccupied berths (beds). Cabins with portholes (outside cabins) are higher priced than those without.

Finally, the Rate sheet and General Information will tell 
the client if seasonal variations in price apply and what special conditions are in effect for children, conditions of deposit and cancellation, sightseeing and use of deck chairs.

Embarcation time is several hours before departure, baggage allowance is far greater than airlines allow. Where the cruise or crossing is part of a larger tour, the connecting flights, coach or rail trip must be realistically matched for time.

Counselling the ocean traveller is often more time consuming and the client relies on the counsellor's guidance and advice to a large extent. Care and accuracy have to be combined with thorough knowledge of the cruises and crossings available.

Study the rate sheets, pages 139 to 146 .

\section{ASSIGNMENT}

Lesson 2

1. In what currency are fares quoted on M. S. Boheme?

2. What is the baggage allowance per person on M. S. Bolero?

3. What is the last date for deposit for the S. S. Fiorita cruise departing July 30 th?

4. Would you recommend cabin 119 on the Forita to a passenger who suffers from claustrophobia and prone to seasickness? Give reasons for your answer.

5. A client has received a Guarantee from T. S. S. Carnivale in respect of a reservation requested for an Upper Deck 
Cabin outside with double bed and shower. Would his request be filled by giving him cabin $\mathrm{R} 63$ which has a double bed and shower? Why?

6. What is an option date? What is a per diem fare calculation?

7. What is the range of prices for cabins in both seasons on the Antilles Deck of M. S. Boheme?

8. Look at the numbering of cabins on M. S. Boheme. Comment on any significant points you observe.

9. As a counsellor you are explaining to a client why cabin prices vary on the same deck. What are FOUR main reasons you would give him?

10. What is included in the price of a cruise? What is not included in the price of a cruise? 
LESSON :

TOPIC :

OBJECTIVES: The student will recognize selling points of cruises in general and handle objections to cruises; he will be equipped to inform clients about the classes of service and to use the basic nautical terms used in shipping.

REFERENCES: Principles and Procedures of Travel Counselling Pages 138 to 142 .

INSTRUCTOR'S NOTES :

Read Section I pages 138 to 142

Selling Features: Several aspects of cruise life can be used to sell the cruise and allow flexibility to suit the passenger's motive, there is the solitude of the ocean or the happy company of crowds on a cruise. Another selling point is that very little additional expense would be incurred once the voyage begins, so the true cost of the vacation is known and can be accurately budgeted. There will be no unpleasant surprises, such as the high cost of dining, as the meals are included in the cruise price. Note, however, that it is only natural for a predominantly Greek or Turkish crew to produce Greek or Turkish style meals. Note also that dinner is normally an extensive meal of 5 to 7 courses. Overcoming objections: A client's existing wardrobe may suffice for cruising purposes. Should extra clothing be needed there are boutiques on board or shopping at the ports of call where clothes can readily be purchased. Class distinctions 
are almost non-existent when it comes to passenger use of facilities even if there are distinctions in class of cabin. Very few passengers make claims to class distinction or superiority so the atmosphere on board is free of restrictiveness.

Tipping, if it proves to be an embarassment, can be done on the advice of the Chief steward or Purser. Other guidelines are: using a percentage of the cost of the cruise as a guide and splitting the amount up among the crew you wish to tip. Where the cruise fares are inclusive of gratuities, it does not mean that an extra tip cannot be given.

Passenger-Freighter Service: Some ports not served by cruise liners can be accessible by using a trading vessel. Note, however, that sailing time and day are at the Captain's discretion and cannot be predicted or guaranteed.

Glossary of Terms: Readl and familiarize yourself with their use. These are all common terms which must be know but are NOT to be used when dealing with a client. Jargon is never used with your client.

Reference Materials: Ask to see these at a Travel Agency where you have introduced yourself. Because of the variations there will be some types of information in one which is omitted in another. Read through several of the listings consulting codes used and strive for a working knowledge of the manuals. 


\section{Lesson 3}

1. What is the regular commission on a cruise?

2. What is the regular commission on a crossing?

3. Give three drawbacks of passenger-freighter travel compared with a regular cruise?

4. How would you advise a client who is worried about tipping on a cruise?

5. What are the roles of the following crew members:

$$
\begin{array}{ll}
\text { Purser } & \text { Deck Steward } \\
\text { Cabin Steward } & \text { Dining Room Steward }
\end{array}
$$

6. What factors influence the price differences between cruise ships?

7. Obtain an Inclusive Tour Charter brochure and a Cruise Brochure. Prepare a comparison of two holidays of similar length. Draw your own conclusion as to which you would recommend to your customer giving reasons. 


\section{LESSON : $\quad$ Four}

TOPIC: $\quad$ Rail Service in North America

OBJECTIVES: The student will know the background to the development of rail service in Canada and the U.S.A.; he will determine the main sales points for rail travel and will know the fare structure for passenger rail service.

REFERENCE: Principles and Procedures of Travel Counselling Pages 148 and 149 .

INSTRUCTOR'S NOTES :

Read Section 2, page 148 and 149.

Rail Travel in Canada: Rail passenger services have survived the strong threat from speedy airline services and flexible automobile travel. There are two main lines, Canadian National and Canadian Pacific ( $\mathrm{CN}$ and $\mathrm{CP}$ ) which travel separate routes and therefore do not compete with each other.

Fare Structure: When determining the fare between points the counsellor needs to consider:

WHEN does the client want to travel, peak, low or internediate periods.

WHICH train will he use, special trains have supplementary charges

WHAT EXTRAS are needed, sleeping couch, meals.

The counsellor could surprise a client and close a sale by pointing out the number of attractive advantages rail travel offers over self-drive, coach and sometimes air service.

1. The space, the freedom to take a long walk on the 
trains so that legs do not cramp, a special advantage on long trips.

2. Rail travel on scenic routes can be an excellent and unrivalled opportunity to see the countryside without the bustle of road traffic and obstructions such as billboards and electricity poles.

3. Some comparative figures may convince your client of the saving he can make, a vacationer intent on economizing could find rail travel an advantage.

4. A saving over air travel is implied since rail services eliminate extra costs of getting to and from the airport. While rail is undeniably slower than air travel, on a short haul the time taken to check in, collecting baggage and travel to and from the airport could amount to the extra hour or two longer which the train takes.

5. The baggage allowance, exceeded only by cruise allowance, would prove attractive to such clients as the cruise passenger making connections from an interior city. Rail travel in the U.S.A.: The notable difference is that there are Amtrak and several small rail lines which provide the service and sales information, thus bookings are not always simple. 


\section{Lesson 4}

1. Do $\mathrm{CN}$ and $\mathrm{CP}$ Rail service the same routes?

2. Can a passenger book CN Rail travel from a CP Rail office and vice versa?

3. Apart from the basic route fare, what extra charges can be applied to a rail fare?

4. What services does a railway offer over a motor coach service?

PRACTICAL ASSIGNMENT

Go to an appointed Travel Agent and obtain individual schedules and tariff sheets of the Railroads and study them. 
TOPIC :

Passenger Rail in Europe and Britain

OBJECTIVES: The student will know the major differences

between rail travel in Canada and Europe, how railways are organized in Europe and the services offered on trains; the student will use tariffs and be able to sell special tickets. (The British Rail system is included above.)

REFERENCES: Principles and Procedures of Travel Counselling Pages 149 to 164

INSTRUCTOR'S 'NOTES :

Read Section 3, page 149.

European rail is fast, efficient, high in quality and therefore popular. Like Canadian rail the fares offer a substantial saving over air travel. For many people rail is the preferred way to travel in Europe. Note that the network of lines is very extensive and almost every small town is serviced by rail, thus the traveller can see the countryside and village life just as easily as the big cities.

Both national and international services are well reputed. There are variations in classes,mainly first and second, and more important, in speed. There are stopping trains, express services and inter-city lines on the TEE (Trans-Europe Express). Note that certain routes are known by the name of the train, which conjures up romantic images for the tourist, eg. the Orient Express and the Trans-Siberian. These are special trains, specially fitted out with individual identities such as the cruise liners. 
Sleepers: Reservations can be made for the sleeping berths with pillow and blanket, called either wagon Lifts or Couchettes, and an extra charge is payable. There are not enough couchettes for every passenger and in summer the demand is so great that last minute reservations might be impossible. Advanced booking is recommended. Note that if the client misses the train there is no refund for the couchette not used. Overnight travel without a couchette is possible since the regular lst class seats are very comfortable, sometimes adjustable, and many tourists catch up on sleep in this manner.

Meals: Restaurant cars are readily available, offering snacks or full meals. Reservations should be made for dining but are unnecessary for purchase of snacks.

Eurailpass: This is an attractive, discounted ticket offering unlimited lst class travel on trains in Western Europe and substantial savings on ferries, scenic cruises and more. The extreme ease of use is another advantage, no further tickets are required, no reservations for a seat, no queueing up in lines. The traveller can board and disembark from trains at will. Students may take advantage of an added discount pass called studentrail Pass, but travel is in 2nd class carriages.

Read Section 4 .

Conditions in Britain are similar to Eropean rail. Here too are specially discounted tourist tickets. The travel counsellor must be thoroughly familiar with the train services of Europe (including the British Isles). Note carefully that 
the special passes are ONLY sold outside of Europe to bona fide tourists, therefore the client needs to decide in Canada if he will use the pass.

Clients may worry about the language problem, and can be reassured that most Europeans know English, and the railway signs are as easy to follow as airport signs.

Baggage allowance is ample, similar to North American allowances, however, separate baggage cars are provided for checking in bulky luggage which canot be stored on the overhead rack in the carriage.

Custom formalities at border crossings are informal and are conducted on board the train as it crosses the border. Passports in order should be on hand and produced on request.

Tipping is not practiced on trains although the restaurant staff could be tipped if desired.

\section{ASSIGNMENT}

Lesson 5

1. What are the three different categories of rail travel in Europe?

2. What do you know about cochettes for lst and 2nd class rail travel in Europe?

3. Outline the sales points for the Eurailpass and the Studentrail Pass tickets.

4. Where can you obtain information about International rail travel in Europe, in Canada?

5. State whether the following statements are true or false. 
a) The TEE is a slow stopping service in rural Europe.

TRUE FALSE

b) Eurorailpass can sometimes be purchased in London .

TRUE FALSE

c) European railroads charge extra for checked luggage.

TRUE

FALSE

d) Cochettes are available to 1st class passengers only.

TRUE

FALSE

6. Refer to the Surcharge Tables on page 161 of the text. What is the name of the Frankfurt-Amsterdan TEE train? Calculate the total surcharge for the Frankfurt (Main) to Duisherg leg for a husband and wife and their 5 year old son. State currency used.

7. Refer to the necessary tables in the text. Extract all the information you would give a client travelling 2nd class round trip Algeciras to Madrid, wishing to obtain a couchette.

8. What is the cost of a lst class one way rail journey from Rome-Paris-Amsterdam-Copenhagen. What extra costs will be incurred in Paris? Calculate the travel time of the rail journeys only.

9. Refers to the Cooks Continental timetable page 152: 
Compare the times of the services offered from Utrecht to Koln (Cologne). Which sevice is faster? How long is the Koln to Bonn trip?

PRACTICAL ASSIGNMENT

Obtain and study the Thomas Cook Continental Timetable and Eurail Tariff and the Easy Guide to British Rail. Obtain the Eurailpass literature and map and study. 
LESSON : $\quad$ Six

TOPIC: $\quad$ Surface Transportation and Tour Planning

OBJECTIVES: The student will understand the importance of bus transportation, the travel agent's relation to sales of bus tickets and tour openings in North America and Europe using bus service; motor car rental companies services, the use of tariffs for bus and car rental.

REFERENCES: Principles and Procedures of Travel Counselling Pages 164 to 167 .

INSTRUCTOR'S NOTES :

Read Section 5 page 164.

The student counsellor must be clear on the difference betweenbuses and coaches in international language in order to counsel his client correctly. Buses are generally the daily public transport service offered for the convenience of the residents of the area. Motor coaches are special transport usually for sightseeing and are more for the convenience of the visitor to the area. Motor coach tours are likely to be offered in vehicles measuring up to minimum standards of space and comfort. Bus services on the other hand, in remote places of the world, can provide a colourful look at local life for the out-going and youthful-minded traveller.

Gray Line coaches are found internationally and can be taken as an indication os the standard of coach service. Another internationally recognized company is Greyhound whose 
extensive bus and coach schedules can be used to plan individual tour routes in North America.

Read SEction 6:

In Europe, the Europabus service is a multinational company which offers bus schedules and tours across all Europe and into the Continent of Asia.

Your client may prefer to select an organized tour which uses a coach as its ground transportation and the same group of people stays with the coach throughout the tour. Such tours are popular in Europe.

Two other types of bus/coach use are as transfers from airport or harbour area to a central terminal, and the chartered bus which has been hired be a common-interest group such as a photographers club.

Read Section 7:

If recommending your client to rent a car, be sure to discuss driving regulations (such as keeping left, strange road signs) the terrain of the country and host country stipulations for International Drivers Permit. Sometimes it may be advisable to point out the perils of driving in such places as Paris or Mexico City. Many rented cars have manual drive. On the other hand, the sale of a car-rental means added flexibility for the traveller who knows what he wants to see and do, and there is a good 15\% commission to be earned by the travel agent. 
1. Distinguish between the uses of a bus, a coach and a rented car from the client's point of view.

2. In what currency are car rentals computed?

3. Consult the Europabus schedule on page 166. On what date would the Brussels-Nice service arrive in Menton if it departed on March 14th? What additional features are offered? What is the cost to a couple who wish a private bath? Which tours are discounted for Eurailpass holders? How Many?

4. How many countries are included in Schedule 170? Name them. What is the cost of the full trip per person?

5. If a client was going on a holiday to Bonaire for one week and wanted to rent a luxury car for the full seven days what would you recommend and what additional information would you give the client?

\section{PRACTICAL ASSIGNMENT}

1. Study the Europabus timetable on page 166 . Consult the reference manuals, Russells' two guides. Obtain and study the Euroabus timetables. Familiarize yourself with their layout, content, coding systems and special features.

2. Study the car rental sheet on page 167 . Obtain the OAG (Official Airline Guide) supplement for Ground Transportation services. Note that it only covers 4 of the major international car rental companies. Note 
also that in Bermuda there are NO car rentals by law: Finally, Canadian and American cars may not be available but equally sound alternative makes are use. Rates will be affected by:

- type of car (category)

- time and place of delivery and return

- local taxes (where applicable)

- chauffeur service

- excess mileage used

- gasoline

- insurance 
TOPIC: Introduction to Types of Tours

OBJECTIVES: The student will define a tour; know the components involved in tours; be introduced to the wide variety of tours and be able to distinguish between categories of tours.

REFERENCES: Principles and Procedures of Travel Counselling Page 169 to 171 .

INSTRUCTOR'S NOTES:

Read Introduction page 169.

TOUR PLANNING COMPONENTS

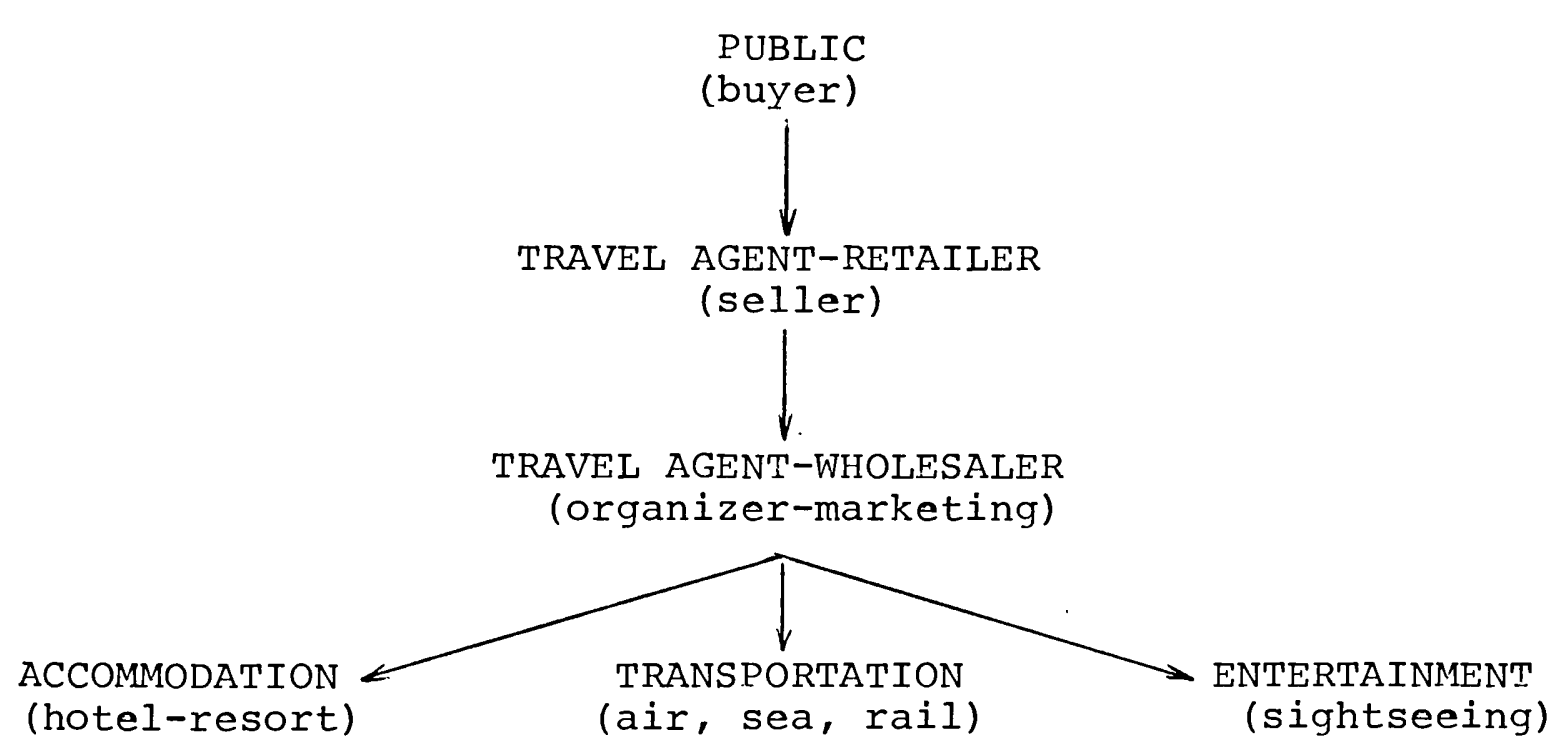

The diagramatical explanation of the components involved in tour planning illustrates the complexity of the travel industry. Tours are extremely popular with the vacationer for reasons which will be discussed later, and because, of this popularity the producers have made available an extensive range for the public. 
Read the definition of a tour carefully, noting that it clearly includes a range of services. These services being prearranged by the Agent, Wholesaler or tour operator and are pre-paid by the client.

The tour operator is the one who actually puts the ideas on paper and organizes the details, the wholesaler puts the tour up for sale and must aware of events which will affect his product. The retailer who counsels the buying public must know the available products.

It can be said that the tour operator is "manufacturing" a product. By planning and organizing the principals of travel, he is producing a new product, a Tour.

Read Section 1:

The massive number of tours available is a reflection on the good business potential available in selling tours. Basic sales psychology applies to selling tours as with any other product, i.e. establishing the motivating forces which will influence your clients decisions. A further investigation of the reason why people travel will be covered in UNIT IV. Read Section 2:

In this lesson we will look at two of the three main categories of tours. Escorted and Independent tours.

Escorted Tours contain these elements:
a) a group of people travelling together
b) a pre-determined number of persons
c) a pre-arranged itinerary
d) an accompanying guide
e) an all inclusive price 
Two different clients may react in opposite ways to these characteristics of the excorted or all inclusive tour. The major selling points are the saving in cost and the assurance of having a guide who knows what has to be done. The major disadvantage is the rigidity of the requirement of doing everything all the time with the same group of people. Independent Tours are for the independent minded client who wants to be involved in deciding what to do and where to go and to go nowhere and do nothing if he should choose to. He can, on an independent tour, make combinations which no planned itinerary covers - he may wish to visit museums every day of his vacation in Paris and to ignore the other activities. His tour cost will be much higher and he will have to fall back on his own resourcefulness if he runs into difficulty. In many cases these clients may not make hotel or other land arrangements in advance because he has no set dates for being anywhere. The counsellor should advise the client of instances, such as Carnival in Trinidad or the "Running of the Bulls" in Pamplona, where it is absolutely essential to make advance reservations. This would prompt the client to make basic reservations and increase the commission to the Travel Agency.

\section{$\underline{\text { ASSIGNMENT }}$}

Lesson 7

1. State whether these statements are true or false:

a) A tour operator can be a wholesale, travel agent. TRUE FALSE 
b) All inclusive tours are pre-paid and escorted by a guide.

TRUE

FALSE

c) Accommodation, transportation and entertainment are always part of the independent tour. TRUE FALSE

d) A retail agent organizes escort tours for large groups.

TRUE

FALSE

e) A package tour is the same as an inclusive tour.

TRIJE

FALSE

2. Explain fully the abbreviations D.I.T. and F.I.T

3. List FIVE characteristics of the conducted tour.

4. List FIVE ways in which the independent tour differs from an escorted tour.

5. List TEN attractions in your area which could be used as a basis for tours. What groups would be interested and where would they come from?

6. Prepare a tour for an attraction or activity in your area. The objective of the programme is to sell the tour through other travel agents to prospective visitors to your area. Prepare all information necessary to sell the tour, such as the brochure, and complete a costing of the tour including your mark-up and the travel agents commission. 
LESSON : $\quad$ Eight

TOPIC: Inclusive Tour Charters I

OBJECTIVES: The student will identify ITC's by their characteristics and requirements.

REFERENCES: Principles and Procedures of Travel Counselling Page 171 .

A Study of The Inclusive Tour Charter Industry in Ontario.

INSTRUCTOR'S NOTES:

Read A Study of the Inclusive Tour Charter Industry in Ontario, Chapter I.

Essentially, ITC's are a new travel product, providing inexpensive vacation packages to popular tourist destinations. They are sold by travel agents and have become such a popular travel product that some travel agents have specialized in this type of trade.

Read Principles and Procedures of Travel Counselling, Page 171, and A Study of the Inclusive Tour Charter Industry in Ontario, Chapter II and III:

It is important that the travel counsellor be knowledgeable about the reasons for the regulations controlling the operation of ITC's. Many questions raised be the travel consumer about ITC's can be answered when you know that the regulations are to protect the consumer.

\section{ASS IGNMENT \\ Lesson 8}

1. Why has the ITC become such a large segment of the travel 
market.

2. What is a back-to-back charter, why are they used and what are their advantages?

3. Write a brief history of the ITC and its influence on the travel market.

4. What are the main regulations on ITC's:
a) Federally
b) Provincially

5. What are the ten main destinations countries for Canadian ITC's.

6. What ITC companies have their headquarters in Metropolitan Toronto?

7. What are some of the causes associated with financial failure of ITC companies?

8. What do you understand by the term vertical Integration in the travel industry? 
LESSON : Nine

TOPIC: Inclusive Tour Charters II

OBJECTIVES: The student will know how an ITC programme is constructed and be able to sell ITC's by stressing the key sales features.

REFERENCES: Principles and Procedures of Travel Counselling page 171 to 174 .

A study of the Inclusive Tour Charter Industry in ontario.

INSTRUCTOR'S NOTES:

Read Principles and Procedures of Travel Counselling, pages 171 and 172 .

Read A Study of the Inclusive Tour Charter Industry in Ontario, Chapter IV:

In summary, the airline is contracted to provide charter flights at agreed dates and times. Suitable hotels and resorts are contracted to accommodate the passengers on the charters at special rates agreed upon by the hoteliers and ITC company. Transfers and other features, such as sightseeing and entertainment are negotiated and contracted for. The final programme is submitted to the airline who in turn presents the request to the Air Transport Committee at least ninety (90) days before the programme is scheduled to begin.

Upon receipt of approval the ITC company can advertise the ITC programme. Travel Agents are often provided with a preview of the ITC programmes through a brochure which is sent to them by the ITC companies and clearly marked "for use by Travel Agents only". In this way the travel counsellor 
is able to study the programmes for the coming season.

Read Principles and Procedures of Travel Counselling, pages 172 and 173 .

Read A Study of the Inclusive Tour Charter Industry in Ontario, Chapter V.

Note, that the ITC does allow the travller a degree of flexibility at the destination. However, the counsellor must be aware of the drawbacks to the ITC and ensure that he sells the product to a client for which it is suited.

Read Principles and Procedures of Travel Counselling, pages 173 and 174 .

Read a Study of the Inclusive Tour Charter Industry in Ontario, Chapter VI.

The travel counsellor must get to know the Inclusive Tour Charter Companies to provide clients with the ITC best suited to their needs. Although the move is towards larger ITC companies, some samll companies become intimately familiar with one or two destinations and offer the best packages to those particular destinations.

\section{$\underline{\text { ASS IGNMENT }}$}

\section{Lesson 9}

1. What are the components of an Inclusive Tour Charter?

2. What are the selling points of Inclusive Tour Charters?

3. Why have hotels in the sun destinations found it convenient to deal with ITC companies?

4. Using the model ITC price calculation form, price the following ITC: 
76 seat aircraft

$\$ 16,000$ total air charter cost

75\% anticipated load factor

7 nights

$\$ 22.00$ hotel room

$\$ 5.00$ transfer per person one way

$\$ 8.00$ night club tour per person

$\$ 5.00$ administration

U.S./Canada \$ at par

Travel Agents Commission 12 1/2\%

5. What are the ways by which ITC companies promote their products?

6. How do travel agents promote ITC's?

7. What is the OTC? Do you think that they will operate to Canada? 
LESSON : $\quad$ Ten

TOPIC: $\quad$ Tour Operators

OBJECTIVES: The student will understand the role of and basic services provided by the tour operator. He will read and interpret confidential tariffs.

REFERENCES: Principles and Procedures of Travel Counsellors page 174 to 189 .

INSTRUCTOR'S NOTES :

Read Section 3, page 174

The student counsellor should not become confused by the multitude of names given to tour operators, or by the fact that one company may be performing a number of roles in the travel industry. However,remember that names refer to the work done

a) creates and/or markets tours

b) contracts with an agency to provide services for a group of travellers.

Confidential Tariffs are issued by the supplier for the use of the retailer. It is important to identify on each tariff if the rates are inclusive of the agent's percentage commission or, if they are not, and if they apply to individuals or groups. With the tariffs, the travel counsellor can construct a tour according to the client's needs, including the F.I.T. individual, for example, he can package an independent tour for the visitor to Sydney, Australia, to cover airport or harbour transfers, hotel accommodation and sightseeing.

The counsellor, acting according to his client's specifications, will then advise the tour operator (in sydney) of the reservations his client has requested. 
- Name of Client

- Number in Party

- Time and Date of Arrival for Transfers

- Accommodation Requested

- Sightseeing requested

- Time and Date of Departure for Transfers.

Study in detail the confidential tariffs shown on page 175 to 188. Pay careful attention to the manner in which the retailer's commission is shown, and if special figures are quoted for groups.

\section{$\underline{\text { ASS IGNMENT }}$ \\ Lesson 10}

1. What is the legal requirement affecting coach transfers in London? What effect will this have on the price of the tour? Identify the favourable general features of these tours from the client's point of view.

2. What essential details are collected about the client for the tour operator when making bookings?

3. Plan a seven night itinerary, giving all details including prices, for an individual who is going to Lima and wishes to arrange sightseeing. Include at least one side trip from Lima to Lake Titicaca and tours around Lima (with lunch where possible). You will suggest suitable types of transportation bearing in mind the client is a school teacher in his thirties. Give the total cost to the client and show the agent's commission.

4. Plan an itinerary for a client travelling to sydney. Include 
hotel, transfers from airport and two full day tours. The client will be staying in sydney for two weeks and has requested that the trip should be "first class": 


\section{LESSON : $\quad$ Eleven}

TOPIC: $\quad$ Product Analysis and Costing of Tours

OBJECTIVES: The student will analyze tours and be able to cost independent tours by the sweeney-Dolly system.

REFERENCES: Principles and Procedures of Travel Counselling Pages 189 to 194 .

INSTRUCTOR'S NOTES:

Read Product Analysis, Section 4 page 189 to 190.

The travel counsellor will be required to read and analyze hundreds of brochures and must learn to do it quickly yet glean the maximum amount of information. Therefore, a systematic approach should be used. The counsellor will be expected to develop his own technique and each will probably be different, but the C.I.T.C Product Checklist will give you a list of what you should be looking for.

Initially, we advise that you thorough in your analysis, later you will find that you can go quicklythrough new brochures.

Read the article "Understanding the Tour Brochure".

Read Section 5, Costing system for Independent Tours, page 190 to 194

Just as a hotel bill ensures that when the guest checks out of a hotel he pays for all the services he has used, so the Sweeney-Dolly system ensures that the travel client is charged for all the services he uses on a tour. The student counsellor should become familiar with the Sweeney-Dolly System and be able to use it when constructing a tour. 
An agent worth his salt

will take time to study

the brochures he

receives. But there are

many things to look out

for.

Too few retail travel agents appreciate the usefulness anrt importance of the tour brochure as a selling tool. More often than not, they hardly take time to review them. Sure, retail agencies are flooded with brochures of tour operators; airlines, steamship companies, hotels, government tourist offices, etc.

But the agent who is worth his salt will malie time to study the various brochures he receives in the course of a business day. The agent that automatically discards brochures without even a cursory inspection, is doing an injustice to himself and may lose many a sale as a result.

The out-dated attitude of some agents to stick with the "tried and the proven" is not always the thing to do. There are agents who give little or no consideration to brochures from lesser known wholesalers or tour operators. For their information, many of these "Johnny come lately's" have really made their mark in the market-place and have left some of the "old boys" standing. Why? To say that your company was eatablished in the 1800's is not good enough these days. Some of the "old boys" have not changed their ' way's or business methods since the 1800's! They have refused to accept change. For example, the days when you could slap-on a 45 percent markup of an FIT has gone out with the horse and buggy. Consequently, the "Johnny come lately's" who have had the courage to introduce new and imaginative programs and marketing techniques have made substantial inroads into the business domain of the old diehards in the business.

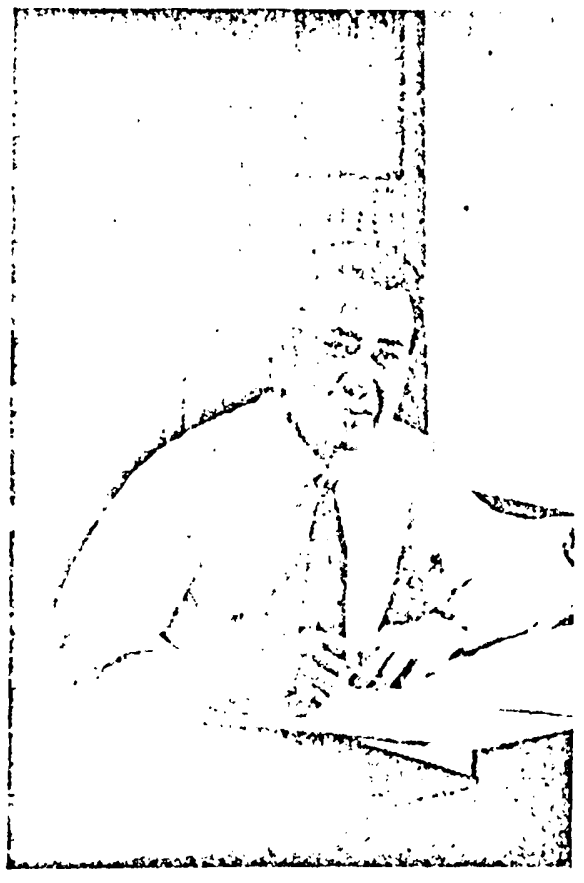

by L.A. da Costa, Jr.

President

World Travel Consultants, Inc.

\section{Keep An Open Mind}

For your own sake, and that of your client, don't ignore the relatively new wholesaler or operator. Many of them are good, honest and experienced people who have struckout on their own because they were employed by companies that had little or no imagination. They are dedicated people who see the need of change in our industry and they should be welcomed with open arms and not with suspicion. Like any business, there is always the "fast-buck artist". These "hit and run" boys bear watching, an 1 you must learn to differentiate the good guys from the bad guys.

\section{Beware of the wholesaler who promises you the moon for only $\$ 299$ and $171 / 2 \%$ commission.}

Let's now get down to some of the "nitty gritiy" of the tour brochure. First, let me point out that humbleds of millions of clollars are spent each year in the production of tour brochures. The main beneficiary of this multi-million dollar enterprise is none other than the printer. The inarket is saturated with programs to the same destinations with virtually the same itineraries and prices. There is a lack of imagination aild creativity in the wholesale tour business. It is so much easier for one operator to copy the program of another than to create something of his own. Because one program has proven successful, everyone else jumps on the band wagon by introducing a similar program but with perhaps a little more dressing up. Unfortunately, there are many followers and too few leaders in our side of the business.

What do you look for in a tour brochure? Again, speaking from experience, too many retail agents tond to sell down than up, making price the main factor in sclecting a brochure for his client. Miost agents will, unfortunately, take the line of least resistance. This approach could cost them the loss of substantial commissions and also repeat business.

(continued on page 5o) 
Tour Brochure

(continued from page 24)

Watch for comc-on prices

One particular broctiure comes to mind. Here the operator offers a tour to French P'o!ynesia for $\$ 699$ including GI'T air fare. The land content is priced at $\$ 152.00$ per person, share basis for 10 nights. Take it from me that neither you or I could buy the same arrangements for an average of $\$ 15.20$ per night. It isn't because you or I do not have the volume to obtain preferential rates from the hotels and ground operators! But, let's examine the brochure a little closer. The tour conditions state that no meals are included, but stronisly urges the purchase of the advance meal plan (\$126 extra). 'Then it goes on to say in solid black print: "Please note that the hotel requires a minimum purchase of Modified American Plan from those clients who do not clect the advance plan." In plain English, whether you like it or not, you are lorced to buy the meal plan.

If Modified American Plan is mandatory, one way or another, why then is it not included in the price and arrangements? Very, simple! The $\$ 699$ is a "comc-on" price even if it means deceiving you and your clicnt. Again, in my opinion, this is out and out dishonesty and misrepresentation. Some would sluff it off as a "marketing technique or gimmick". I cannot accent that.

Also in this same brochure it is stated that the 4 percent Room Tax is not included and will be collected from each hotel on departure checkout. It's like saying that you're buying the tour but your bed is not included and you have to pay for it when you checkout.

If you will add up the cost of meals, the 4 percent room tax and the $\$ 699$ basic price tag, the total cost would be approximately $\$ 850.00$ per person. Now, that package does not look as attractive, does it? But, you and your client will know the truth and that's what counts.

\section{Look for quality}

When you buy a dress or suit, you generally know what you want in quality and styling before you venture out in scarch of it. If the quality and styling of a particular dress or suit fulfills nearly all your

fancies, you're going to pay the price for it even if it's going to cost you more than you had plamned on paying. The same applies to tours. When a customer shops for a tour. he knows more or less what he wants and the price he's willing to pay. First try to fit the tour to his individual needs without considering price. If the tour you have selected meets all his requirements, he will pay the price. If you started out with a lower priced package that did not offer as much, he may have settled for it, and you would have lost some commission. It's like buying a car. How many of us actually pay the sticker price on a floor model at a car showroom? After we add up the extras for the white sidewalls tires, automatic transmission, airconditioning, etc., we pay for what we wanted in the first place.

Price, therefore, is not the sule determining factor. Before you look at the price tag, review the tour itinerary and conditions. The contents of the itinerary - quaiity of arcommodetions, meal plari, sightsceing, etc., dictate and determines the cost of the tour. If it's a stripped down model, it is obviously going to cost less.

Assuming, you've been in the travel business for some years and have traveled extensiveiy. It would not be difficult for you to evaluate the value of one tour compared with another. By simply taking the. cost of the land arrangements and dividing it by the tntal number of nights, you'll arrive at a "daily average cost". Let's use the South Pacific in our illustration. If the average daily land cost of a 21 day tour is approximately $\$ 55$ to $\$ 61$ per day, I'll say you have a pretty good tour, provided all the uther ingredients (accommodations, meals, sightsceing, etc.) are good and in sulficient quantity.

If a similar tour is priced considerably lower, your alert light should be turned on. It obviously cannot contain as good or as much arrangements as the other tour selling for several hundred dollars more. Don't he taken in by that sales pitch that because of volume buying, one operator can do better than the other price-wise. Yes, volume might give one operator an edge, but not that much that the cost of land arrangements could be 
fice, he will move on to another easier target.

Most burglaries of travel agencies are part of a carefully drawn plan to produce financial gain. 'They are not crimes of passion, and they are not done on the spur of the moment. If the risk of committing the burglary appears greater than the gain, the burglar will pass you by.

The best liability insurance you callobtain is full compliance with Schedule B, Minimum Security of the $\Lambda$ TC Sales Agency Agreement. If you maintain good minimum security, and if you keep only the allowable number of air tickels on hand, you will not be fince or suspended, and you will not have to pay for any stolen tickets after your agency is burglarized.

If you are burglarized, touch nothing, telephone your local police, and after the police have taticn an inventory of your stolen tickets, teleplione quickly and then telegraph the information to the Executive Secretary of ATC.

\section{Tour Brochure}

(continued from page 57)

several hundred dollars less. Just remember that there are no bargains in travel. The old axiom that you get just what you pay for holds true also in travel.

- There is a certain amount of "dressing-up" of tour brochures especially in copy writing which tend to over-glamorize a particular destination, sightseeing tour or hotel. If you're experienced and well-traveled, you'll know these situations when they arise.

Then there are those who would do all most anything to make their product look better than it really is. For example, a tour may be advertised - and so stated in the brochure - to include two meals every day. But, in reading on, you find that inflight meals are also included in the two meals per day. In taking out the inflight meals, you might become disillusioned to find that not that many meals are included. Personally, I feel this is not the right thing to do as inflight meals are included in the cost of
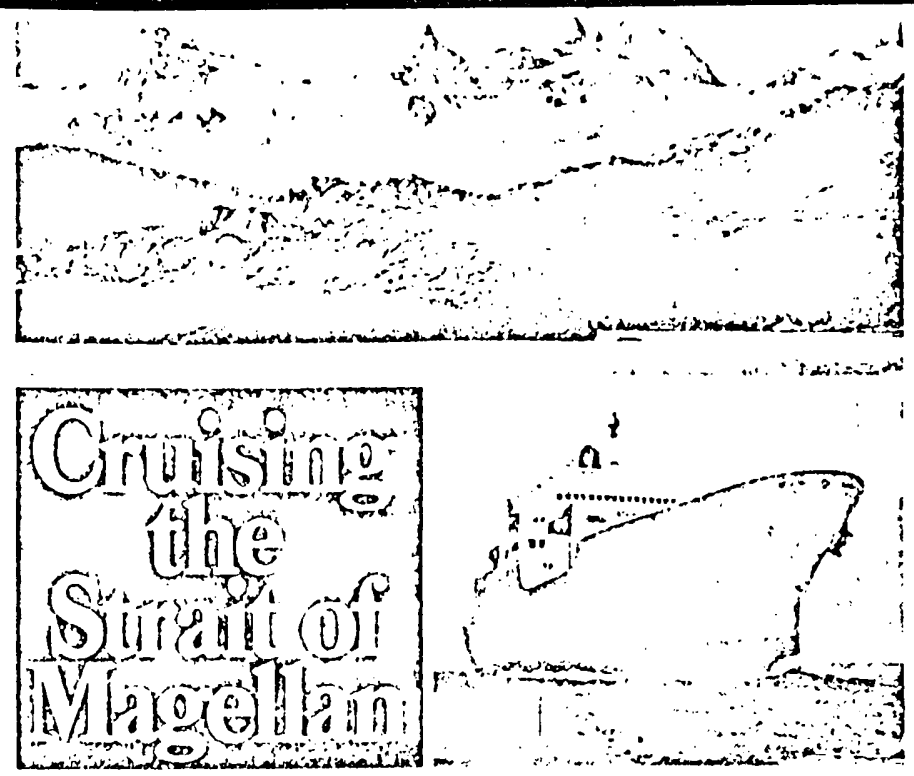

Sailings cuery two weeks. Only Prudential Cruises can show your clients the snowy splendor of the Strait of Magellan, which sumasses even Norway's fjords and Alaska's Inside Passage. Perhaps no other place in the world is as breathtaking. And it's just one of 16 destinations on our cruises to and around South America. Sailings from Vancouver, Tacoma, San Fran. cisco, and Los Angeles on modern American SANTA Lincrs. Tell your clients about Prudential's Join.Anywhere Leave. Anywhere Cruises.

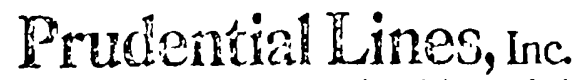

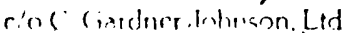

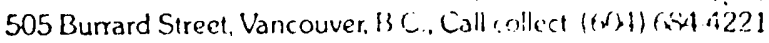

the air fare and should be separated from the ground content of the itinerary'.

As a professional travel counselor, it is your responsibility to place before your client the choice of several tours that may best suit his individual travel needs. Then, it is up to you to give him your professional guidance and experience in selecting the right one. However, before you cain give him your expert opinion and advice, you have an obligation to your client and yourself to thoroughly examine the brochures. In other words, you must know your product.

If you sell him a tour which does not fit his social stature for example, you're likely to lose all his future business.

Be open-minded in selecting a tour for your client and don't le! commissions or personal favorites influence your decision entirely. Remember, the client keeps you in business and it is his or her interests that yor: must consider above all things.

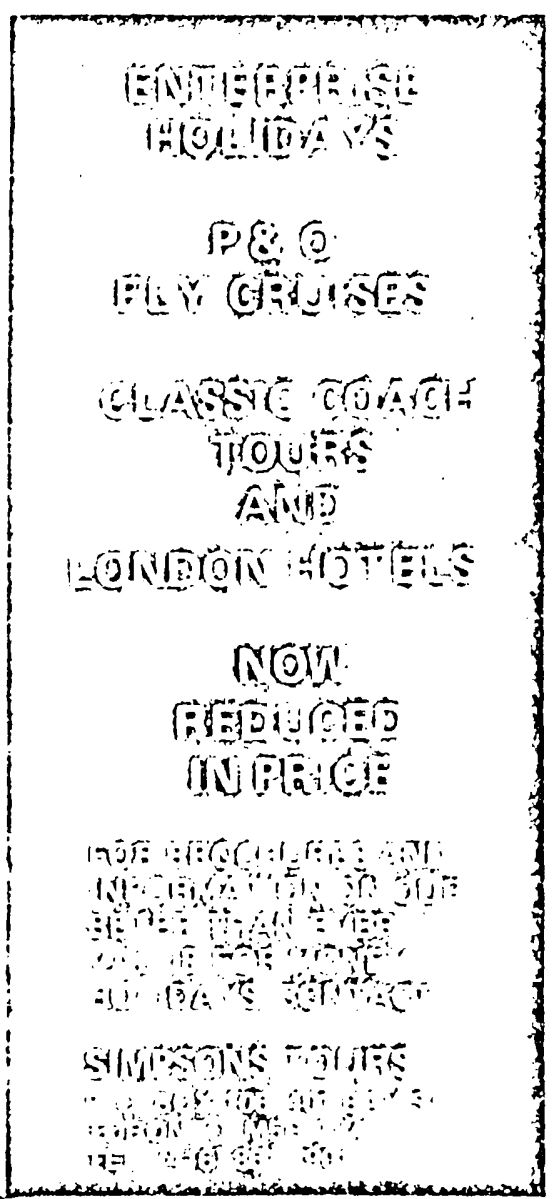


Lesson 11

1. By using the Product Study Checklist a counsellor will obtain what benefits?

2. Obtain three brochures of tours, F.I.T., I.T.C. and D.I.T. and complete the Product Study on each, using the Product study Checklist. Submit the brochures and your analysis for marking.

3. The Sweeney-Dolly system of costing a tour is used for what types of tours? Why is it used?

4. From the information on page 175 to 188 plan a 7 day tour to any destination. Calculate the selling price of the tour and the travel agent's commission using the SweeneyDolly system. Prepare the information you would present to your client and the information you would use at the travel agency. 
LESSON : $\quad$ Twelve

TOPIC: Airline Promotion of Tours and Reference Materials

OBJECTIVES: The student will know the reasons for airline participation in the tour industry and be able to recognize an ATC and IATA recognized tours and complete an Air Tour Sales Report Form.

REFERENCES: Principles and Procedures of Travel Counselling, Pages 194 to 208 .

INSTRUCTOR'S NOTES :

Read Airlines Promotion of Tours, Page 194 to 197.

A working knowledge of Group Inclusive Tours (GIT), Individual Inclusive Tours (IIT) and Contract Built Inclusive Tours (CBIT - pronounced see Bit) is essential to the travel counsellor. Read the section about the requirements of the tours thoroughly.

C.A.T.M. The Consolidated Air Tour Manual is a listing of ATC recognized Advertised Air Tours. Look at the examples on pages 199 to 208 .

Read Section 7, Key Sales Features, and Section 8, Reference Materials.

\section{ASSIGNMENT \\ Lesson 12}

1. What two general strategies are used by airlines to encourage travel agents to sell their tours?

2. Give the full name and explanation of th following:
a) G.I.T.
b) I.I.T. 
c) C.B.I.T.

3. Obtain a brochure for each of the following programmes: G.I.T., I.I.T. and C.B.I.T. Note the rules and regulation for each and submit for marking.

4. Choose any three ATC recognized tours and complete the attached facsimile of an Air Tour Sales Report form $(\mathrm{ATC}-4)$.

5. What is an override? How much is the override when an air ticket is sold in conjunction with an IATA approved tour?

6. What is the CATM? Who publishes it? What is it used for?

7. Explain the procedure in booking an Advertised Air Tour published in the CATM.

8. a) What is the cost of the CATM?

b) The CATM covers what geographical area?

9. Using the sample of the CATM pages 199 to 208, find tours suitable for the following clients. Write what you would explain to your clients.

a) A two day inexpensive tour to Vancouver for two persons.

b) A one week trip to Walt Disney World for a budget minded family of four, children ages 14 and 15 .

c) A luxury, one week trip, to Hawaii for a single elderly lady.

d) A tennis holiday for a young couple who are economy conscious.

e) A four night Hawaiian Island Tour of the outer islands. The party consist of three young school teachers.

f) A moderately priced tour of San Fransisco. 


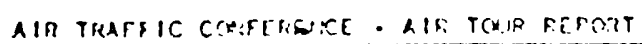

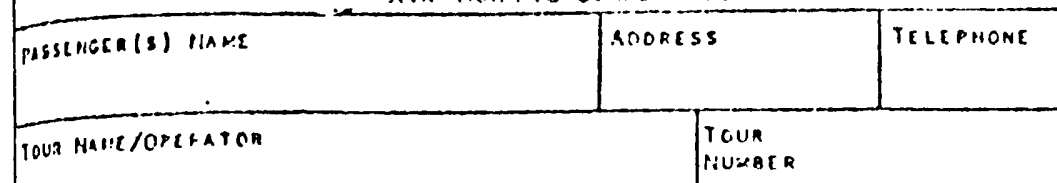

issuto in COMHECTION WITH

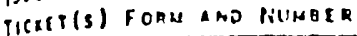

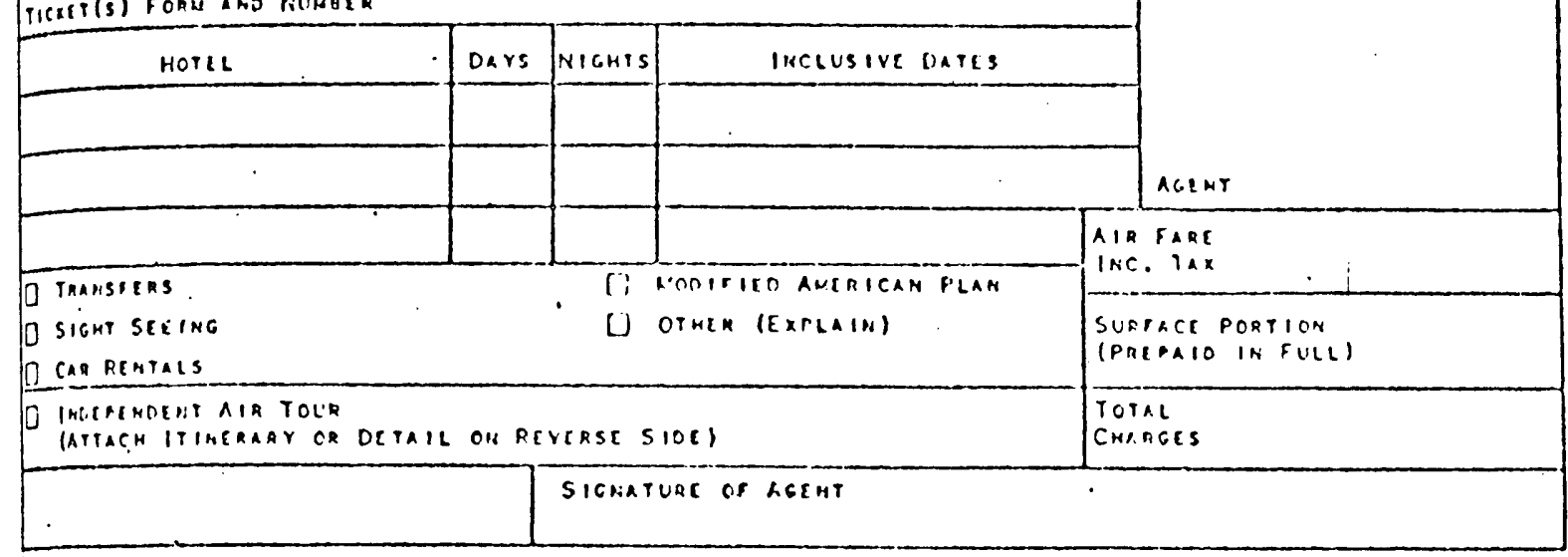

'Facsimile of an Air Tour Sales fieport Form (ATC.1). To be completed by selling counsellor and submitted with auditor's coupon's) of the Airline Ticket(s) issued in connection with the tour.

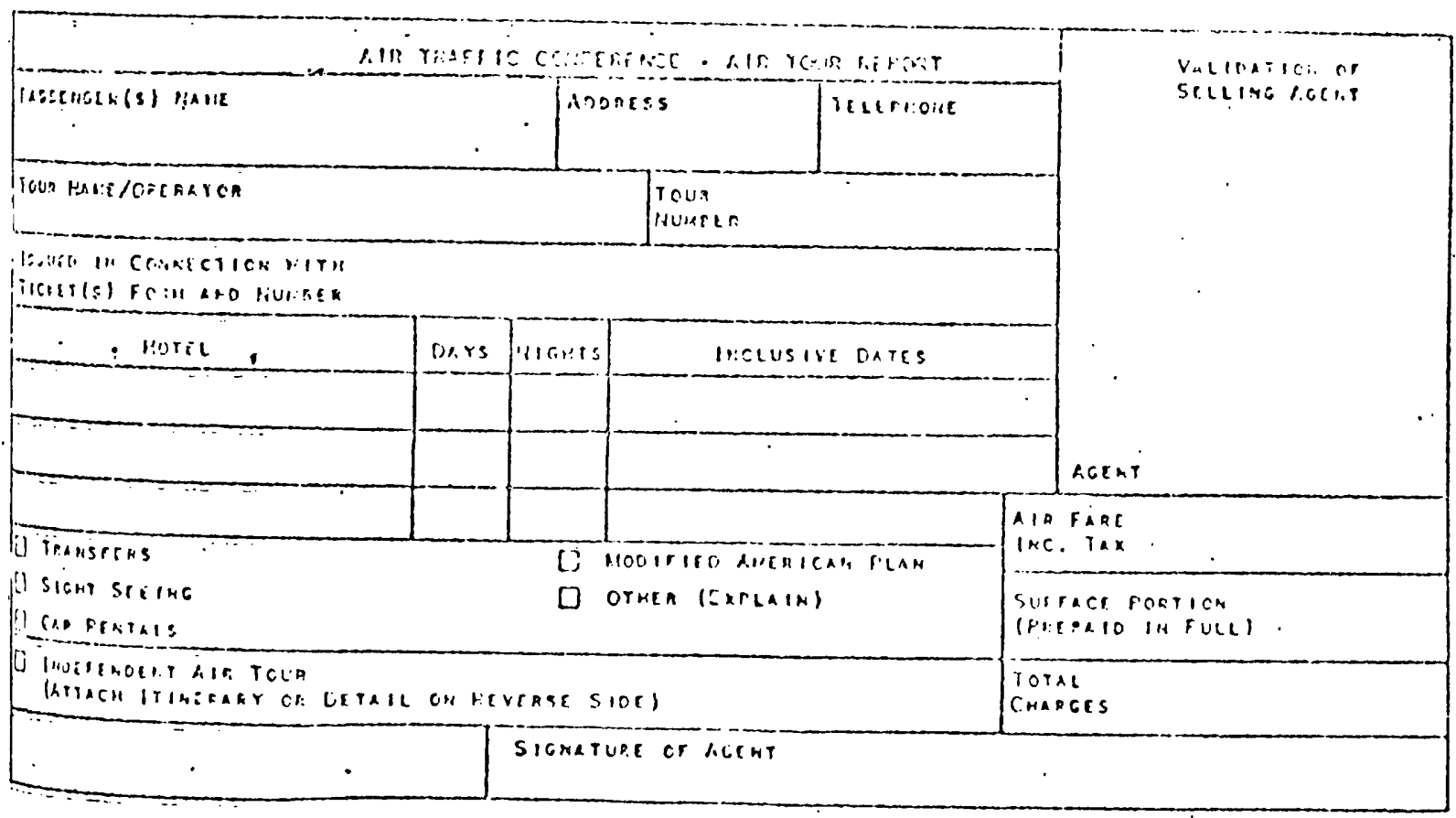

'Focsimile of aln Air Tour Sales Report Form (ATC-4). To bn compleied by sellinin coun.ellor and Wunitted with auditor's coupon's) of the Airline Ticket(s) issued in conncetion brith the tour. 
1. Mr. and Mrs. A. Cooper and their daughter, Susan, 9 years old, select the Royal Canadian Tour as described in the accompanying CATM page, with deluxe hotels, triple basis.

They wish to leave YYZ July 4, 1975 and commence the tour on that date. Using the accompanying OAG page reserve $\mathrm{Y}$ Class on the first nonstop $\mathrm{CP}$ flight in the day. They wish to come home on the day the tour finishes; reserve the last AC non-stop flight, Y Class, in the day for them. Use fare-sheet also accompanying this paper.

Issue all three tickets and one A.T.O. for the family. Form of payment is cash.

2. Re: Mr. \& Mrs. A. G. Ralston and Daughter Terry, nine years old. The family seeks your advise and assistance for reservations on the S.S. Doric Cruise, May 10, 1975. They wish an Upper Deck Stateroom with sitting bath, shower and toilet.

Upon requesting accommodation for the clients from the Home Lines Inc., the ship line offers a choice of Cabin \#107 or 134. (See accompanying deck plan and rate-sheet).

a) Which of the two cabins would you recommend the Ralston family accept? Why? 
EFFECTIVE: ARRIL 27, 1975. 2nd REVISION

CANADIAN INSTITUTLOE

TRAVEL COUNSELLORS OF ONTARIO

NORTH AMERICAN

\section{INTRA-CANADA FARES}

\begin{tabular}{|c|c|c|c|c|c|c|c|c|c|c|c|c|c|}
\hline & \multicolumn{2}{|c|}{$\begin{array}{l}\text { NORMAL } \\
\text { FARES }\end{array}$} & \multicolumn{2}{|c|}{$\begin{array}{l}\text { IAUILY PLAN } \\
\text { SPOUSE OR } \\
\text { FIRST CH!LD }\end{array}$} & \multicolumn{2}{|c|}{$\begin{array}{c}\text { FAMILY PLAN } \\
\text { CHILDREN } \\
12-21\end{array}$} & \multicolumn{2}{|c|}{$\begin{array}{c}\text { CHILDREN } \\
2-11\end{array}$} & \multirow{2}{*}{$\begin{array}{r}\text { EX } \\
8: 30 \\
\text { DAYS } \\
Y\end{array}$} & \multirow{2}{*}{\begin{tabular}{|c|} 
OFF \\
PEAK \\
FARE \\
$Y$ \\
\end{tabular}} & \multirow{2}{*}{$\begin{array}{c}\text { YOUTH } \\
Y \\
\end{array}$} & \multirow{2}{*}{$\begin{array}{l}\text { SENIOR } \\
\text { CIT. } \\
Y \\
\end{array}$} & \multirow{2}{*}{$\begin{array}{l}\text { GROUP } \\
\text { RATE } \\
Y\end{array}$} \\
\hline & $\mathrm{F}$ & Y & $\mathrm{F}$ & $Y$ & $\mathrm{~F}$ & $Y$ & $\mathrm{~F}$ & $Y$ & & & & & \\
\hline $\begin{array}{l}\text { CALACARY } \\
\text { CHARLOTTETOWN } \\
\text { EDNONTON } \\
\text { FRLDERICTON } \\
\text { GANDER } \\
\text { HALIFAX }\end{array}$ & $\begin{array}{r}174.00 \\
103.00 \\
174.00 \\
87.00 \\
145.00 \\
100.00\end{array}$ & $\begin{array}{r}120.00 \\
71.00 \\
12.0 .00 \\
60.00 \\
100.00 \\
69.00\end{array}$ & $\begin{array}{r}144.45 \\
8.5 .50 \\
144.45 \\
72.25 \\
120.35 \\
83.00\end{array}$ & $\begin{array}{l}99.65 \\
58.95 \\
99.65 \\
49.85 \\
83.05 \\
5730\end{array}$ & $\begin{array}{r}144.45 \\
35.50 \\
144.45 \\
72.25 \\
120.35 \\
83.00\end{array}$ & $\begin{array}{l}99.65 \\
58.95 \\
99.65 \\
49.65 \\
83.05 \\
5730\end{array}$ & $\begin{array}{r}116.05 \\
68.70 \\
116.05 \\
58.00 \\
96.70 \\
66.79\end{array}$ & $\begin{array}{l}80.00 \\
47.35 \\
30.00 \\
40.00 \\
66.70 \\
46.00\end{array}$ & $\begin{array}{r}168.00 \\
99.00 \\
168.00 \\
140.00 \\
97.00\end{array}$ & 42.00 & $\begin{array}{l}96.00 \\
57.00 \\
96.00 \\
48.00 \\
80.00 \\
55.00\end{array}$ & $\begin{array}{r}108.00 \\
64.00 \\
108.00 \\
54.00 \\
90.00 \\
62.00\end{array}$ & $\begin{array}{r}108.00 \\
64.00 \\
108.00 \\
54.00 \\
30.00 \\
62.00\end{array}$ \\
\hline $\begin{array}{l}\text { LONOON, ONT. } \\
\text { MONCTON } \\
\text { MONTREAL } \\
\text { NORTH BAY } \\
\text { OTTAWA }\end{array}$ & $\begin{array}{l}26.00 \\
94.00 \\
54.00 \\
42.00 \\
45.00\end{array}$ & $\begin{array}{l}18.00 \\
65.00 \\
37.00 \\
29.00 \\
31.00\end{array}$ & $\begin{array}{l}21.60 \\
73.05 \\
44.55 \\
34.90 \\
37.35\end{array}$ & $\begin{array}{l}14.95 \\
54.00 \\
30.75 \\
24.10 \\
25.75\end{array}$ & $\begin{array}{l}21.60 \\
78.05 \\
44.85 \\
34.90 \\
37.35\end{array}$ & $\begin{array}{l}14.95 \\
54.00 \\
30.75 \\
24.10 \\
25.75\end{array}$ & $\begin{array}{l}17.35 \\
62.70 \\
36.00 \\
26.00 \\
30.00\end{array}$ & $\begin{array}{l}12.00 \\
43.35 \\
24.70 \\
17.35 \\
20.70\end{array}$ & 91.00 & $\begin{array}{l}13.00 \\
26.00 \\
20.00 \\
22.00\end{array}$ & $\begin{array}{l}14.00 \\
52.00 \\
30.00 \\
23.00 \\
25.00\end{array}$ & $\begin{array}{l}16.00 \\
59.00 \\
33.00 \\
26.00 \\
28.00\end{array}$ & $\begin{array}{l}16.00 \\
59.00 \\
33.00 \\
26.00 \\
28.00\end{array}$ \\
\hline $\begin{array}{l}\text { OUEBEC } \\
\text { REGINA } \\
\text { ROUYN NORANDA } \\
\text { SAINT JOHN N.B. } \\
\text { ST. JOHNS NFLD }\end{array}$ & $\begin{array}{r}68.00 \\
141.00 \\
64.00 \\
88.00 \\
145.00\end{array}$ & $\begin{array}{r}47.00 \\
97.00 \\
44.00 \\
61.00 \\
100.00\end{array}$ & $\begin{array}{r}56.45 \\
117.05 \\
53.15 \\
73.05 \\
120.35\end{array}$ & $\begin{array}{l}39.05 \\
80.55 \\
36.55 \\
50.65 \\
83.05\end{array}$ & $\begin{array}{r}56.45 \\
117.05 \\
53.15 \\
73.05 \\
120.35\end{array}$ & $\begin{array}{l}39.05 \\
80.55 \\
36.55 \\
50.65 \\
83.05\end{array}$ & $\begin{array}{r}45.35 \\
94.05 \\
42.70 \\
58.70 \\
96.70\end{array}$ & $\begin{array}{l}31.35 \\
64.70 \\
29.35 \\
40.70 \\
66.70\end{array}$ & 140.00 & $\begin{array}{l}33.00 \\
31.00 \\
43.00\end{array}$ & $\begin{array}{l}3910 \\
78.00 \\
35.00 \\
49.00 \\
80.00\end{array}$ & $\begin{array}{l}12.00 \\
87.00 \\
40.00 \\
55.00 \\
90.00\end{array}$ & $\begin{array}{l}42.00 \\
37.00 \\
40.00 \\
55.00 \\
90.00\end{array}$ \\
\hline $\begin{array}{l}\text { SASKA TOON } \\
\text { SAULT STE MARIE } \\
\text { SEVEN ISLANDS } \\
\text { STEPHENVILLE } \\
\text { SUDBURY }\end{array}$ & $\begin{array}{r}149.00 \\
54.00 \\
99.00 \\
131.00 \\
44.00\end{array}$ & $\begin{array}{r}103.00 \\
37.00 \\
68.00 \\
90.00 \\
30.00\end{array}$ & $\begin{array}{r}123.70 \\
44.85 \\
82.20 \\
108.75 \\
36.55\end{array}$ & $\begin{array}{l}8550 \\
30.75 \\
56.45 \\
74.75 \\
24.95\end{array}$ & $\begin{array}{r}123.70 \\
44.85 \\
82.20 \\
108.75 \\
36.55\end{array}$ & $\begin{array}{l}85.50 \\
.30 .75 \\
56.45 \\
74.75 \\
24.95\end{array}$ & $\begin{array}{l}99.40 \\
36.00 \\
66.00 \\
87.40 \\
29.35\end{array}$ & $\begin{array}{l}68.70 \\
24.70 \\
45.35 \\
60.00 \\
20.00\end{array}$ & $\begin{array}{r}144.00 \\
95.00 \\
126.00\end{array}$ & 21.00 & $\begin{array}{l}82.00 \\
30.00 \\
54.00 \\
72.00 \\
24.00\end{array}$ & $\begin{array}{l}93.00 \\
33.00 \\
61.00 \\
81.00 \\
27.00\end{array}$ & $\begin{array}{l}93.00 \\
33.00 \\
61.00 \\
81.00 \\
27.00\end{array}$ \\
\hline $\begin{array}{l}\text { SYDNEY } \\
\text { THUNDER BAY } \\
\text { TIMMIINS } \\
\text { VALD'OR } \\
\text { VANCOUIVER }\end{array}$ & $\begin{array}{r}116.00 \\
78.00 \\
58.00 \\
64.00 \\
207.00\end{array}$ & $\begin{array}{r}80.00 \\
54.00 \\
40.00 \\
44.00 \\
143.00\end{array}$ & $\begin{array}{r}96.30 \\
64.75 \\
48.15 \\
53.15 \\
171.85\end{array}$ & $\begin{array}{r}66.45 \\
44.85 \\
33.25 \\
36.55 \\
118.70\end{array}$ & $\begin{array}{l}96.30 \\
64.75 \\
48.15 \\
53.15 \\
171.85\end{array}$ & $\begin{array}{l}66.45 \\
44.85 \\
33.25 \\
36.55 \\
118.70\end{array}$ & $\begin{array}{l}77.40 \\
52.00 \\
38.70 \\
42.70 \\
138.05\end{array}$ & $\begin{array}{l}53.35 \\
36.00 \\
26.70 \\
29.35 \\
95.35\end{array}$ & 112.00 & $\begin{array}{l}38.00 \\
28.00 \\
31.00\end{array}$ & $\begin{array}{r}64.00 \\
43.00 \\
32.00 \\
35.00 \\
114.00\end{array}$ & $\begin{array}{r}72.00 \\
49.00 \\
36.00 \\
40.00 \\
129.00\end{array}$ & $\begin{array}{r}72.00 \\
49.00 \\
36.00 \\
40.00 \\
129.00\end{array}$ \\
\hline $\begin{array}{l}\text { VICTORIA } \\
\text { WINDSOR } \\
\text { WINPIPEG } \\
\text { YARPIDUTH }\end{array}$ & $\begin{array}{r}212.00 \\
41.00 \\
112.00 \\
100.00\end{array}$ & $\begin{array}{r}146.00 \\
28.00 \\
77.00 \\
69.00\end{array}$ & $\begin{array}{r}176.00 \\
34.05 \\
93.00 \\
83.00\end{array}$ & $\begin{array}{r}12120 \\
2325 \\
63.95 \\
5730\end{array}$ & $\begin{array}{r}176.00 \\
34.05 \\
93.00 \\
83.00\end{array}$ & $\mid \begin{array}{c}12120 \\
2325 \\
63.95 \\
5730\end{array}$ & $\begin{array}{r}141.35 \\
27.35 \\
74.70 \\
66.70\end{array}$ & $\begin{array}{l}97.35 \\
18.70 \\
51.35 \\
16.00\end{array}$ & $\begin{array}{r}204.00 \\
108.00 \\
97.00\end{array}$ & 20.00 & $\begin{array}{r}117.00 \\
22.00 \\
62.00 \\
55.00\end{array}$ & $\begin{array}{r}131.00 \\
25.00 \\
69.00 \\
62.00\end{array}$ & $\begin{array}{r}131.00 \\
25.00 \\
69.00 \\
62.00\end{array}$ \\
\hline
\end{tabular}


APPLIES ON FIRST AND ECONOMY. CLASS YEAR ROUND. HEAD OF FAMILY, NORMAL ADUL.T FARE, ACCOMPANYING SPOUSE OR FIRST ACCOMPANYING CHILD $12-21,83 \%$ OF FULL ADULT FARE. ADOITIONAL CHILUREN 1 2-21, 83\% OF ADULT FARE. CHILDREN 2-11, 66-2/3\% OF ADULT FARE. HEAD OF FAMILY MAYY BE EITHER THE HUSEAND OR THE W'IFE. ONE INFANT MAY BE CARRIED FREE WITH EACH PASSENGER 12 YEARS OF AGE AND OVER.

BESIRICIIONS EAMULY FARE PLAN

- NOT VALID FOR TRAVEL FRIDAY AND SUNDAY

- NOT VALID DURING FOLL OWING HOLIDAY PEAKS, JUN $28-30$ AND JUL 1, DEC $20-24$, JAN 2 - 5, MAR. 27 AND 31.

\section{8-30 DAY ECONOMY EXCURSION - YEC 30}

RETURN PORTION OF TICKET APPLIES ON FLIGHTS SCHEDULED TO DEPART NOT EARLIER THAN 8 DAYS NOR LATER THAN 30 DAYS IN ADDITION TO THE DATE OF DEPARTURE FROM POINT OF ORIGIN OF THE OUTBOUND FORTHON OF THE TICKET.

END ON COMBINATION WILL NOT BE PERMITTED UNLESS TRAVEL IS VIA THE POINT OF COMBINATION.

RESTRICTIONS 8 - 30 DAY EXCURSION

- NOT VALIO FOR TRAVEL FRI AND SUN 1501 - 2059

- NOT VALID DURING FOLLOWING HOLIDAY PEAKS, JUN 1 - SEP 30, DEC $20-24$, JAN 2 - 5, MAR. 27 AND 31

- NO STOPOVERS PERMITTED INO CHILDREN'S DISCOUNTS/NO FAMILY FARE PLAN DISCOUNTS.

OFF-PEAK ECONOMY FARES - YW

THESE FARES APPLY ONLY BETWEEN THE POINTS SHOWN. ONE-WAY OFF-PEAK FARES MAY BE USED IN COMBINATION WITH OTHER ONE-WAY FIRST/ECONOMY CLASS FARES FOR NORMAL OR CIRCLE TRIP TRANSPORTATION.

\section{RESTRICTIONS OFF-PEAK FARES}

- ONLY VALID ON FLIGHTS SHEDULED TO DEPART BETWEEN MIDNITE FRIDAY UNTIL 1501 SUNDAY

- FAMILY FARE PLAN AND CHILDREN'S DISCOUNTS IVILL NOT APPLY

- END ON COMBINATION WILL NOT BE PERMITTED UNLESS TRAVEL IS VIA THE POINT OF COMBINATION - NOT VALID DURING HOLIDAY PEAKS OF JUN 28-29 DEC 21,22. JAN 4,5.

\section{YOUTH FARES - YZ}

20\% DISCOUNT FOR PASSENGERS AT LEAST 12 YEARS OF AGE BUT LESS THAN 22 YEARS OF AGE, WHO IS THE HOLDER OF A YOUTH FARE IDENTIFICATION CARD.

- NOT VALID FOR TRAVEL FRIDAY AND SUNDAY

- NOT VALID FOR TRAVEL DURING FOLLOWING HOLIDAY PEAKS, JUN 28 - 30 AND JUL 1, DEC 20 - 24, JAN 2 - 5, MAR. 27 AND 31.

- STANDBY BASIS ONLY, NO RESERVATIONS PERMITTED

SENIOR CITIZEN FARES - YCD

THESE FARES APPLY TO PASSENGERS WHO ARE NOT LESS THAN 65 YEARS OF AGE, AND MUST BE THE HOLDER OF A SENIOR CITIZEN IDENTIFICATION CARD. PASSENGERS MAY BOOK RESERVATIONS.

\section{RESTRICTIONS ON SENIOR CITIZEN FARES}

- NOT VALID FOR TRAVEL TRIDAY AND SUNDAY

- NOT VALIO FOR TRAVEL DURING FOLLOWING HOLIDAY PEAKS, JUN 28-30 AND JUL 1, DEC $20-24$, JAN 2 - 5, MAR. 27 AND 31

GROUP FARES - YG

10\% DISCOUNT FOR GROUPS OF 15 OR MORE TRAVELLING TOGETHER. GROUPS MAY EITHER ORIGINATE GR TERMINATE TOGETHER AND TRAVEL SEPARATELY IN THE OPPOSITE DIRECTION

\section{RESTRICTIOINS ON GROUP FARES}

- NOT VALID FOR TRAVEL FRI. AND SUN. 1501 - 2059.

- NOT VALID DURING FOLLOWING HOLIDAY PEAKS JUN. $28-30$, JUL. 1, DEC. $20-24$, JAN. 2 - 5, MAR. 27 AND $31 .^{\circ}$ 
TOLR: CANAIIAN VORTHWEST HOIII)AYS

NORTIIWEST SCFIC TOLR

WESTWIND AINENTLRE TOL RS

TOL'R: ITIST

ROYAL CANADIAN TOLR $\operatorname{ITRC} 9$

PER PERSON RATES FFFICTIVE: December 31, 1974 hrough December 31.1975

ITNS6

N(OR IIIWFST S(ENIC TOLR - 6 I)AIS - 5 NICIITS

Vancouver/hamloops/Lahe Louise/Banff/Calgary-or reverse

DAILY: June 5 to Sept. 15

ITINFRARY:

Ist Das: Arrive Vancouter, transfer to hotel, overnight.

Ind Day: Sightsecing of Vancouver, overnight.

Jrd Day: Trans Candal llighwaty escorted tour, dinner. overnght in Kamloops

th Daty: Breakfast. Contunue to Calgary via I.ake Louise. Banfl, overnaght Calgary.

Sth Day: Sightsecing in Calghry. aftermom free

toth Day: Transfer to Calgary airpore lor highte heme.

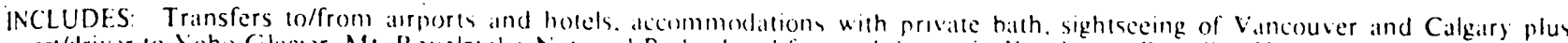

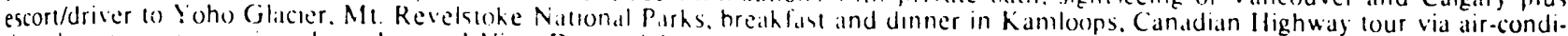
tioned, rest rooms. equipped coaches and Vista Dome sightseemg coaches.

\begin{tabular}{|l|c|c|}
\hline & Single & Double \\
\hline First Class Holels & S220.00 & Trinle \\
\hline Deluxe Hoteh & 248.00 & S198.00 \\
\hline
\end{tabular}

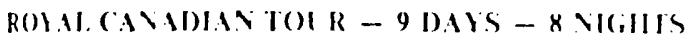

lancouser/tictoria/kambons/lahe Louise/Banff/Columbia leefield-or reverse.

TOUR: ITRC

DAlLY: June 2 - Septemiter 14

lat Day Arrice Vancouver, tranafer to hotel. overnght.

2nci bat Sightsecing of lincouser. orernight.

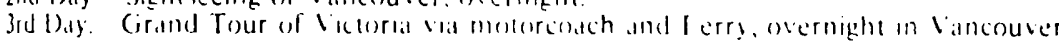

4h Daly: Trans Canada Highual escorled tour, dinner. overnght in kamloons.

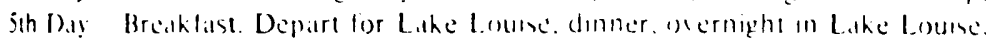

foth Bay: Breakfist, all day tour to Columbia leefield. continue to Banff. dinner. overnight in Banff

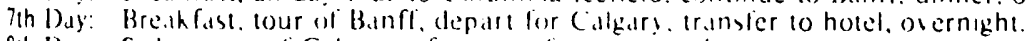

8ih Day: Sightseeing of Calgary, afternoon free. overnight.

9h Day: Transfer to Calgary for Highe home.

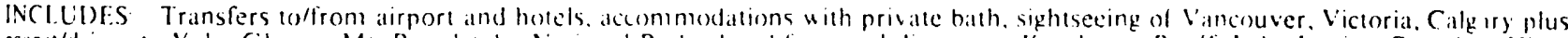
escort/driter to Yoho Glacier. Mt. Revelstoke Nattional Parks, breahfasts and dinners in Kamloops, Banfl. Lake Louise. Canadlian llighwaj tour via air-conditioned restrooms equipped coaches and Vista Dome sightseeing coaches.

\begin{tabular}{|l|c|c|c|}
\hline & Single & Double & Triple \\
\hline Deluxe Holels & $\$ 376.00$ & $\$ .358 .00$ & $\$ 3335.00$ \\
\hline
\end{tabular}

DAlty: January 1 to June 2, Sept. 15- Dec. 31. Trans Canada Highway Tours does not operate, add arrfare between Vancouver/ Calgary. Request rates.

FLY/DRIVE OPTION: Package rates for itinerary to the Northwest. On request.

FIRST CLASS HOTELS Sheraton Landmark (Vancouver). Stockmens Hotel (Kamloops) MAt. Rosal Hotel (Banfl). Deer Lodge Hotel (Lake Louise). Palliser Hotel (Calgary)

- DFHUXE HOTELS. Hotel Vancouver (Vancouver), Canadian Inn (Kamloops), Chateau Lake Louise (Lake Louise). Banff Springs (Banfl).

- (algary inn (Calgary).

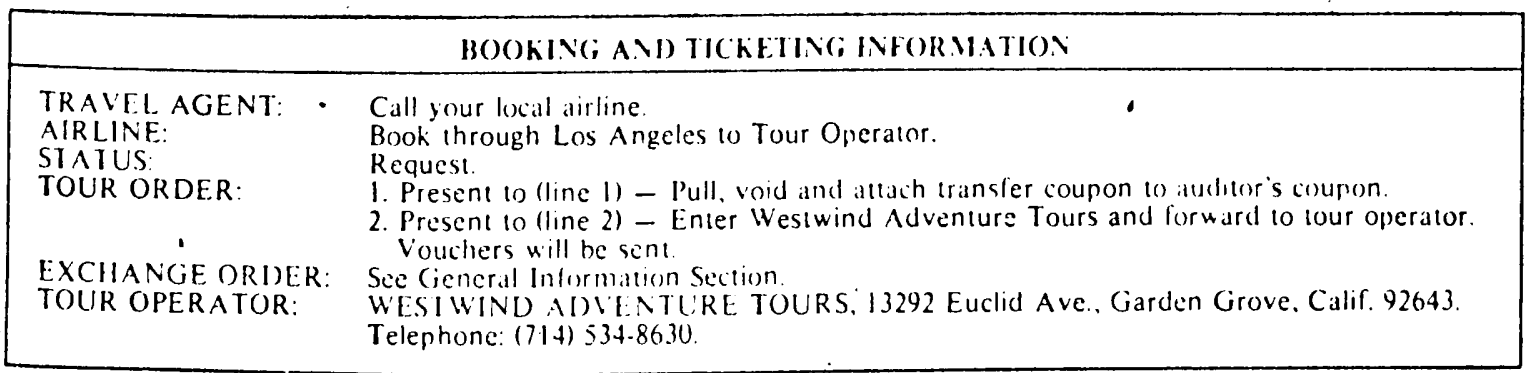


b) Show the per person fare plus port taxes, and the grand total of the Cruise fare and taxes for the family.

c) The tonnage of the Doric is 25,300 GRT, the Cruise capacity of the ship is 725 passengers. What is the space-ratio per passenger?

d) Miss Helen Smith asks for reservations for herself alone on the Upper Deck of the Doric, June 3rd Cruise, in an inside room. The Line confirms the Upper Deck accommodation to you on behalf of Miss Smith in a cabin with two beds; the fare quoted is $\$ 1,035$. The room is the nearest to the stern of the ship in the fare category quoted, and is on the starboard side. What is the room number?

e) Specify three likely extra expenses these cruise passengers might have to pay for while on the cruise which are not included in the fare.

f) Issue air ticket for Miss Smith assuming the following flights are confirmed.

$\begin{array}{llll}\text { June 03.75 } & \text { YYZ-LGA } & \text { AA442 } & \\ 0935 / 1048 & \text { Y Class: } & \$ 43.00 & \text { OW } \\ & & & \\ \text { June 15.75 } & \text { JFK-YYZ } & \text { AC781 } & \\ 1650 / 1815 & \text { F Class: } & \$ 60.00 & \text { OW }\end{array}$

Chargex Credit Care \#4510208244 402 is the form of payment.

2. Product Study

Three single ladies plan to reserve the WAIKIKI ADVENTURE 
TOUR, as described on the accompanying page which is a reproduction in part of an actual tour brochure.

a) What is the price for each of the three on a triple basis?

b) What is the price each person will pay if they decide on twin basis plus a single?

C) What is the period of validity of the brochure?

d) Specify the IT number?

e) Name the tour operator.

f) These clients wish to take the tour but travel to and from Hawaii on another carrier. Can they do so and still pay the same price?

g) Is a normal of an excursion fare used in connection with the tour? specify type used.

h) If the ladies decide to remain in Hawaii at the end of the tour for another few days before flying home, can they do so?

i) How many breakfasts are included in the tour package?

j) How much baggage will the tour operator undertake to handle for each passenger?

k) The ladies ask you for details as to the flight time (departure and arrival) in connection with the tour They are an ious to know what flights they would be booked on. How do you obtain this information?

1) They also ask the name of the Hotel they will be staying at in Honolulu. How do you obtain this information?

m) The ladies read over the brochure and see mention is 


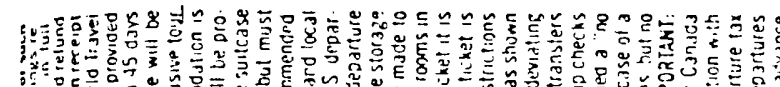

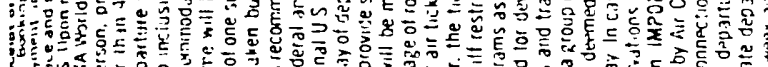

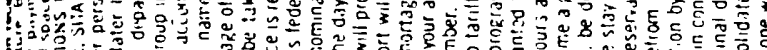

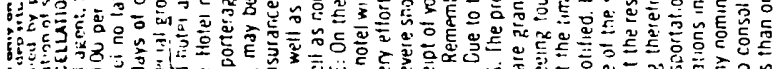

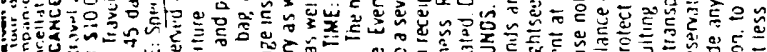

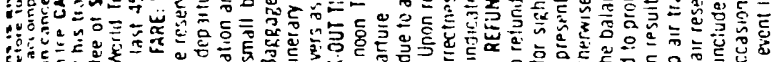

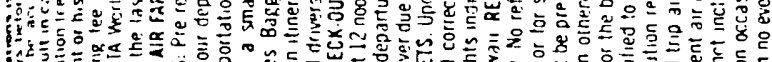

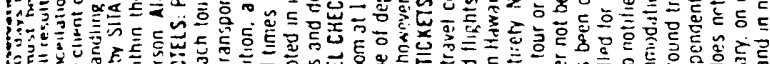

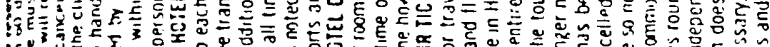

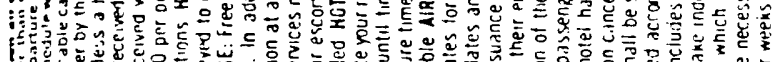

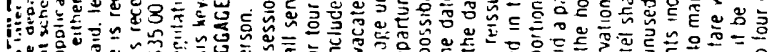

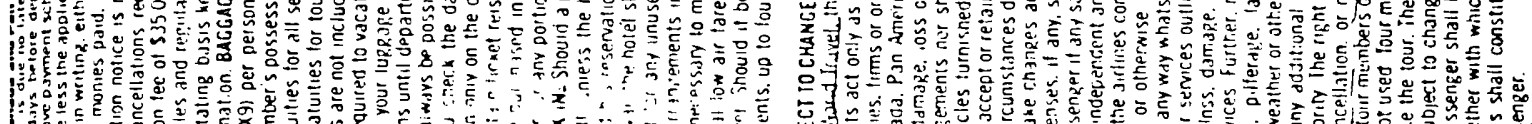

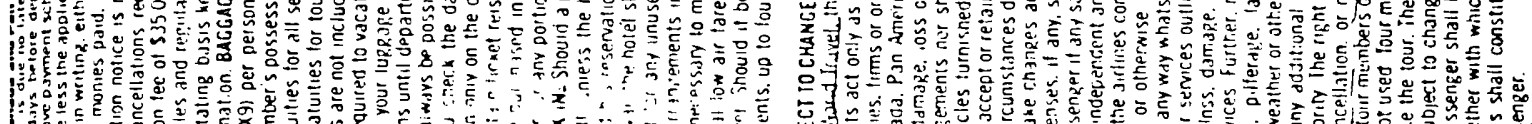

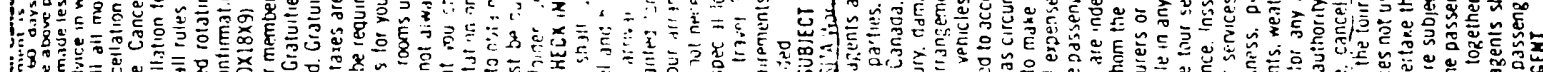

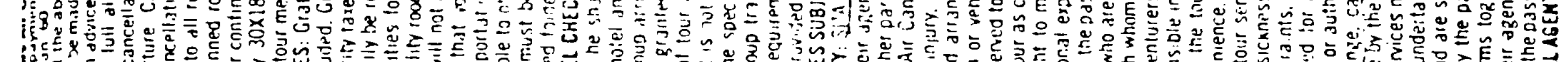
界 When

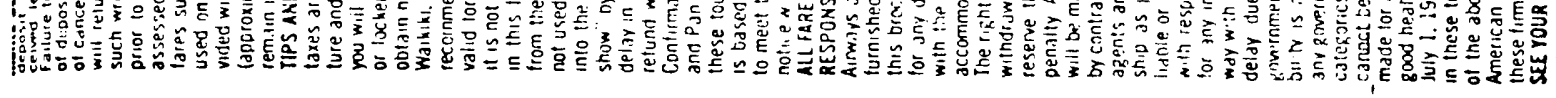

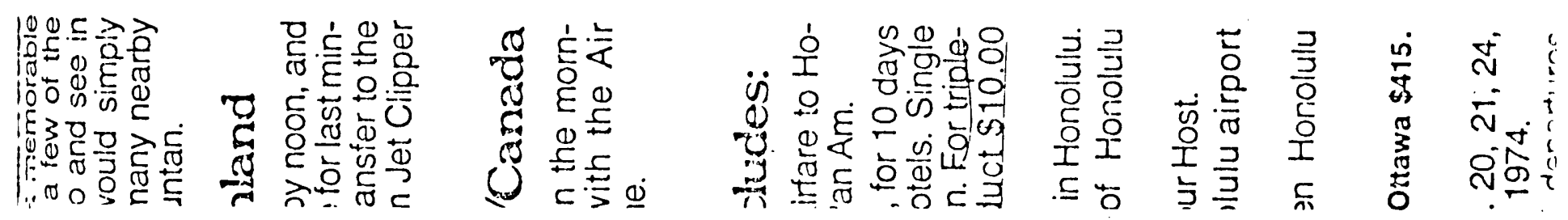


made about the "luau", the traditional Hawaiian feast, and a cruise to Pearl Harbour. Are these items included in the tour?

n) Before the tour operator will confirm reservations for your clients, what does he require?

4. Using the tariff material provided with this paper, prepare a cost-sheet for a London Tour for a group of eleven Rotary Club members and their wives. Arrival date in London is June 05. You may design the tour to include the specified sightseeing on any day you wish; be sure to show the dayby-day items included. Remember, this is a Cost-sheet for internal use by a travel agency; no descriptive copy is required.

The Specifications are:

- TWB with breakfast and S/C and VA tax at the London-TARA Hotel for three nights (departure from LON June 08).

- Round trip transfers between LHR and the London-TARA Hotel.

- Full-day London sightseeing.

- Half-day Windsor Castle Tour.

- $10 \%$ profit to be added to the total. (for ease in calculation, determine total of the above costs for one PAX and multiply by eleven). 


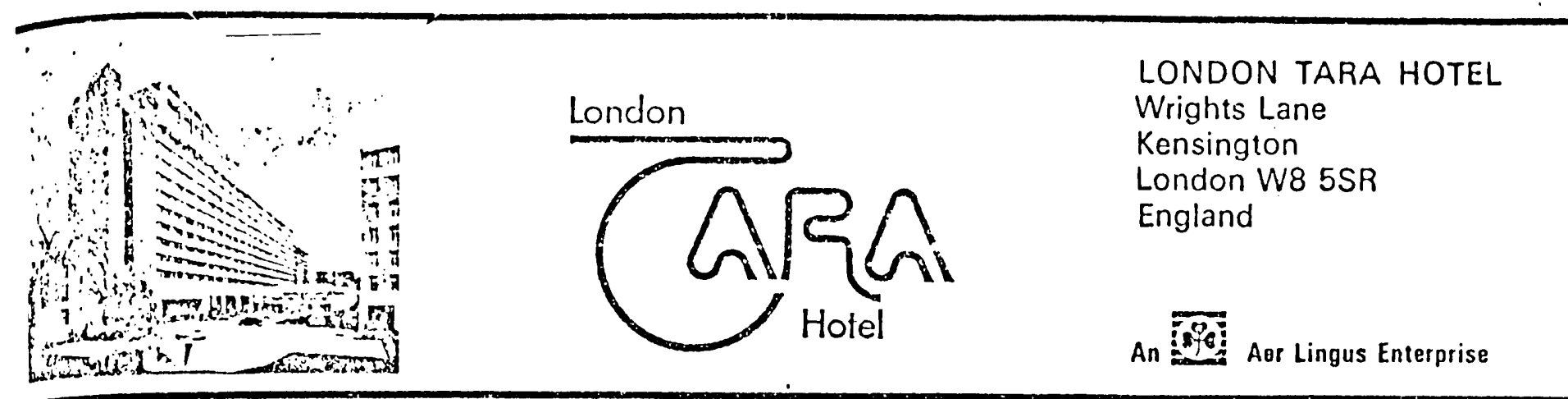

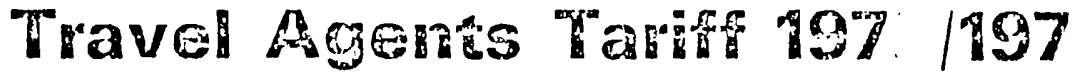

The London Tara Hotol opened February 1973 850 rooms: extensive conference \& banquet rooms

\begin{tabular}{|c|c|c|c|c|c|}
\hline \multicolumn{2}{|c|}{$\begin{array}{l}\text { INDIVIDUALS (F.I.T.) } \\
\text { DAILY ROOM RATE (European Plan) }\end{array}$} & \multicolumn{2}{|c|}{$\begin{array}{l}1 \text { APR } 1973 \text { to } \\
31 \text { OCT } 1973\end{array}$} & \multicolumn{2}{|c|}{$\begin{array}{l}1 \text { NOV } 1973 \text { 10 } \\
31 \text { MAR } 1974\end{array}$} \\
\hline \multirow[t]{2}{*}{ SINGLE ROOM } & \multirow{2}{*}{$\begin{array}{l}\text { min. } \\
\text { med. }\end{array}$} & $\begin{array}{l}\mathrm{f} \\
6.75\end{array}$ & $\begin{array}{l}\text { US \$* } \\
16.90\end{array}$ & $\begin{array}{l}\varepsilon \\
6.00\end{array}$ & $\begin{array}{l}\text { US \$ } \\
15.00\end{array}$ \\
\hline & & 7.75 & 19.35 & 7.00 & 17.50 \\
\hline EXECUTIVE SINGLE & $\max$. & 10.00 & 25.00 & 9.00 & 22.50 \\
\hline DOUBLEBEDDED ROOM & (2 persons) & 8.50 & 21.25 & 7.50 & 18.75 \\
\hline TWINBEDDED ROOM & (2 persons) & 9.50 & 23.75 & 8.50 & 21.25 \\
\hline EXECUTIVE ROOM & (2 persons) & 13.50 & 33.75 & 11.00 & 27.50 \\
\hline SUITES & from & 24.00 & 60.00 & 20.00 & 50.00 \\
\hline THIRD BED RATE & & 2.25 & 5.60 & 2.00 & 5.00 \\
\hline
\end{tabular}

BREAKFAST RATE (Additional to the room rates shown)

Continental 55p. $\$ 1.40$

Continental Breakfast is available in the room or in the Coffee Grill.

\section{ALL RATES ARE INCLUSIVE OF SERVICE}

ALL ROOMS HAVE TWO BEDS OR DOUBLE BED SUITABLE FOR TWIN OCCUPANCY ALL WITH BATH, SHOWER, DIRECT DIALLING TELEPHONE, AUTOMATIC CALL SYSTEM, T.V. AND RADIO
English 90p. $\$ 2.25$

English breakfast is only available in the Tara Coffee Grill

AGENTS COMMISSION: $10 \%$ on room rate which is inclusive of Service.
GROUP RATES (non commissionable) inclusive of continental breakfast and service
All group rates are per person and available only to bona fide tour operators and travel agents PAYABLE NET TO HOTEL 
All rates are net, in pounds sterling, and include VAT

\section{Transfers}

The rates quoted are net per person in Pounds Sterling and include the following elements:

* Transportation by luxury chartered motorcoach

* Services of Supertravel's uniformed representatives

* Porterage of $\mathbf{2 0 . 4 0}$ per person to cover ino bags per person at both pick-up point and destination (not applicable to Evenıng Transfers)

is Coach Driver's gratuity *Value Added Tax (VAT)

Airports, Docks etc per person

1 Railioad Station or City Termınal

'2. I rndion (Heathrow) Airport

3 London (Gatwick) Airport

4 Dover Marine or Harwich Docks

Combination Transfer pernerson Heathrow transfer combined with half day

Windsor sightseeing (incl entrance fees)

Evening Theatre Transfers per person

Allowing 5 hours and 20 miles

Allowing 6 hours and 60 miles

$\begin{array}{rrrr}15-24 & 25-34 & 35-49 & 50 \ldots \\ \mathrm{f} 1.95 & £ 1.80 & £ 1.25 & £ 1.15 \\ 2.25 & 2.00 & 1.55 & 1.25 \\ 2.70 & 2.30 & 1.80 & 1.40 \\ 4.15 & 3.00 & 2.35 & 1.80 \\ 15-24 & 25-34 & 35-49 & 50- \\ £ 3.25^{\circ} & £ 2.55 & £ 2.15 & £ 1.85 \\ 15-24 & 25-34 & 35-49 & 50+ \\ f 2.15 & £ 1.45 & £ 1.05 & £ 0.95 \\ 3.10 & 1.85 & 1.35 & 1.10\end{array}$

\section{Sightseeing}

The rates quoted are net per person in Pounds Sterling and include the following elements:

* Transportation by luxury chartesed motricoach

* Services of Supertravel's uniformed trillind quide

* Entrance Fees - in London at places mentioned, outsude 1 ondon at all places of major interest on the tour.

* Coach Driver's gratuity * Value Added Tax (VA1)
London Area per person

1 Half-day London West End

(Including entri - cos at Westminster Abber)

2 Half-day London-City

(Including entrancers at Tower of London and Jewel House)

3 Full-day London

(Including entrances 101 and 2 above)

4 Half-day Windsor

(Includingentrance in Castle State Anariments and Si rie cars Chapel)

5 Full-day Windsor and Hampton Court

(including Hampion Court Palace and 4 above)

Outside London per person

1 ininhirn Ahhou,
$15-24$

£2.15

25-34

£1.60

35-49

£1.30

50.

\subsection{5}

2.00

1.65

£1.15.

4.30

2.95

2.45

1.45

3.10

2.15

1.85

2.25

4.70

3.20

2.55

1.70

2.20

15-24

$25-34$
เ 2 ก

35-49

คว $\Delta$ ก

$50+$

$f 1$ an 
5. Mr. \& Mrs. Fred Henderson consult with you to arrange cruise rservations aboard the S.S. Doric (see accompanying material provided with this exam paper) for the May 10, 1975 sailing. They are interested in obtaining a stateroom on the Upper Deck with sitting bath, shower and toilet. The ship line offers them a choice of reservation in either room \#107 or \#133.

a) Which of the two staterooms would you advise the Hendersons to accept? Why?

b) Assume that the Hendersons take along their 9 year old daughter, show the per person cruise fare, plus port taxes and the grand total of the fares and taxes that you would collect from them.

c) State commission earned on the above sale.

d) Three singles are confirmed in U-184k April 29 cruise. Show individual fares to collected. (Port taxes not required to be shown).

e) A single lady asks for a reservation on the Upper Deck June 3rd sailing, in an inside room all to herself. The ship line confirms accommodation in a state room with two beds, the fare quoted being $\$ 1035$. The room is the nearest one to the stern of the ship in the fare category quoted, on the starboard side. What is the room number?

6. Mr. \& Mrs. R. Walker and son Ted 15 years selct the walt Disney World package described in the accompanying CATM page. They select delux accommodation, triple basis, checking in 
PER PERSON RATES EFFECTIVE: October 15, 1974 to December 15, 1975

RATES INCLUDE HOTEL TAXES

\begin{tabular}{|l|c|c|c|c|c|}
\hline & Single & Double & Triple & Quad & $\begin{array}{c}\text { Child } \\
\text { under 12 }\end{array}$ \\
\hline $\begin{array}{l}\text { Economy - 3 Days - 2 Nights } \\
\text { ITSHOH200 }\end{array}$ & $\$ 85.00$ & $\$ 49.00$ & $\$ 37.00$ & $\$ 31.00$ & $\$ 12.00$ \\
\hline EXTRA NIGHT & 35.36 & 17.68 & 11.80 & 9.00 & Free \\
\hline $\begin{array}{l}\text { Deluxe - 4 Days - 3 Nights } \\
\text { ITSHOH300 }\end{array}$ & 133.00 & 79.00 & 61.00 & 52.00 & 20.00 \\
\hline EXTRA NIGHT & 35.36 & 17.68 & 11.80 & 9.00 & Free \\
\hline
\end{tabular}

ECONOMY TOUR INCLUDES:

1. Two nights deluxe accommodation at the Orlando Hyatt House.

2. Round trip airport/hotel transfers.

3. Admission and 8 attraction tickets to Walt Disney World including unlimited use of Monorail System.

4. Free transportation to and from Walt Disney World and Hotel.

5. Children under 12 years free (when sharing existing bed space with adults - Hotel only).

\section{DELUXE TOUR INCLUDES:}

All the above plus!

1. One extra night at the Orlando Hyatt House.

2. One more admission and 8 attraction tickets to Walt Disney World.

3. Admission to Sea World of Florida and its 125 acres of live marine animal shows.

\section{BOOKING AND TICKETING INFORMATION}

TRAVEL AGENT: Call your local airline office.

AIRLINE:

Hyatt Reservations (800) 228-9000.

STATUS:

Request.

TOUR ORDER: - 1. Present to (line 1) - Hyatt Representative at Orlando Airport Information Center.

2. Present to (line 2) - Hyatt Hotel Desk.

EXCH.ANGE ORDER: See General Information Section.

TOUR OPERATOR: ORLANDO HYATT HOUSE, 1-. \& U.S. 192 East, Kissimmee, Florida 32741. Telephone: (305) 846-4100. WATTS Line: (800) 228-9000. 


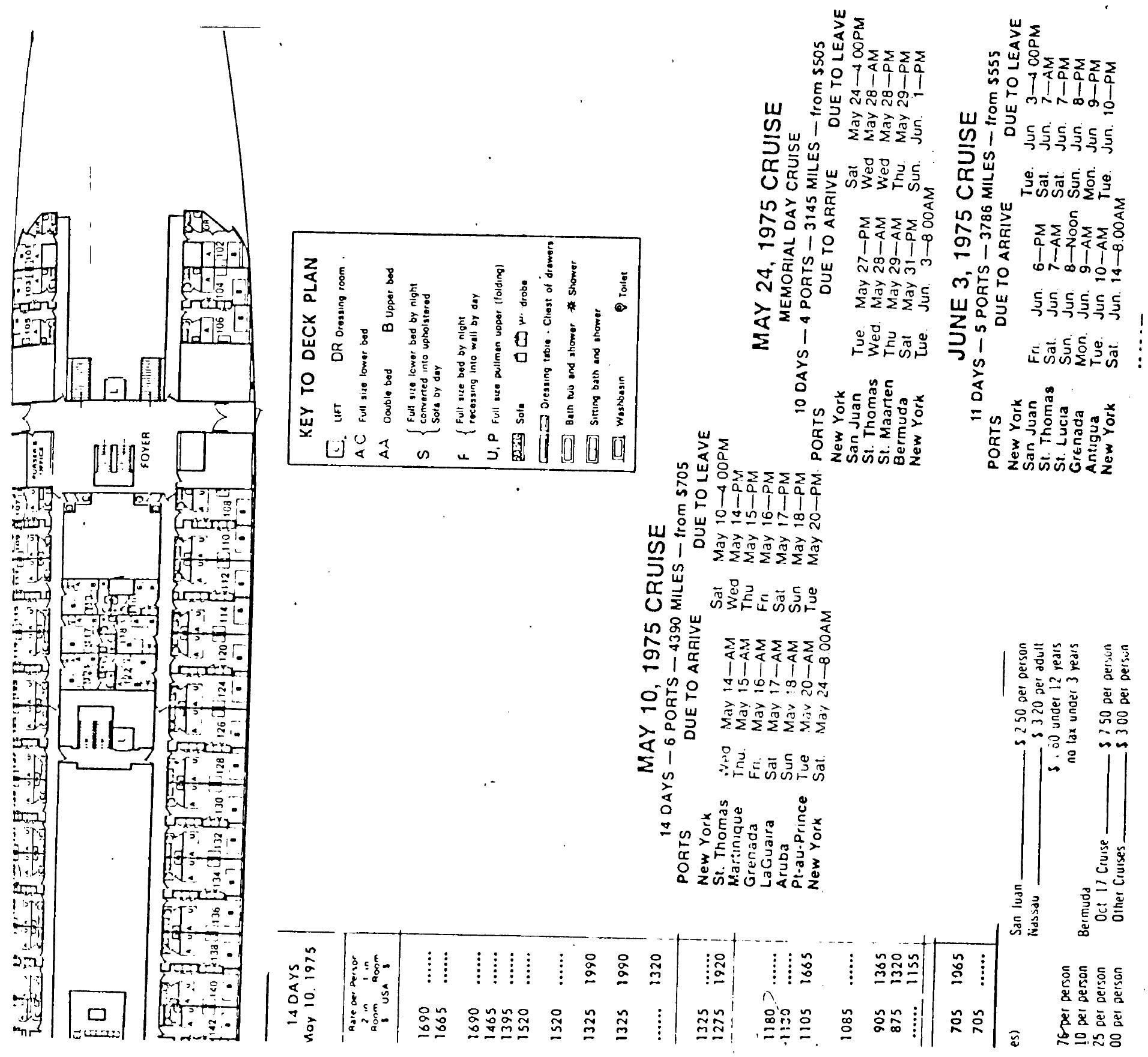


on May 30, 1976, checking out on June 3, 1976.
a) Show clearly all your calculations.
b) Issue an airline Tour Order for the package. Assume arrival flight at Orlando is EA 481, departure flight WA239.

7. Using the material in your textbook, show the departure time from Venezia S.L. (Venice) and arrival time at Gare de Lyon, Paris, of the TRANS EUROP EXPRESS train CISALPIN.

What is the applicable fare in USD to be collected for this journey ow? Describe a Eurailpass: What is it? Who is eligible to use it? Where can it be purchased? Where can it be used? What class of travel does it provide?

8. Mr. \& Mrs. Jones plan a trip, with your help, to Europe. They purchase a 45-day excursion fare between Toronto and Barcelona and you make flight reservations for them to leave on May 29. They do not require any accommodations in BCN. They plan to arrange ship transportation on their own to the Island of Palma de Mallorca. The Jones ask you to reserve accommodation for them in a superior TWB at the Hotel SON VIDA on Palma, commencing with their arrival on the early afternoon of June 02 for a stay of six nights, full AP. The desired reservation is confirmed to you by the Hotel Rep., subject to a full prepayment of the accommodation, AP, service charges and taxes.

a) At the outset, what documents do you ensure that these 
clients will have in their possession for their trip?

b) Using the Hotel San Vida tariff in the CITC textbook (figure 78), show the total prepayment you would collect from the Joneses, in pesetas.

c) Using your OAG, select suitable flights for the Jones family between $\mathrm{YYZ}$ and $\mathrm{BCN}$ in accordance with the above flight dates and record the complete itinerary on a Yellow Route-Sheet. Issue only one ticket, for Mr. Bill Jones.

Obtain and use the fare shown in the Trans Atlantic Air Tariff sample page in the CITC Textbook. (Figure 20) State the date of publication of the OAG that you are using •

9. Using the accompanying Hilton International rate schedule, determine the following; be sure to show all calculations:

a) At the Kensington-Hilton, London, England, what is the total in Pounds sterling for a top-rate TWB, including s/c and taxes, check-in February 27, 1975; check-out March 02, 1975. No meals.

b) Minimum-rate triple at the Jerusalem-Hilton with Continental breakfasts (CB), check-in May 14, 1975, check-out May 16. Total should include service-charges and should be in Israeli Pounds.

c) Show commission earned in (c) abové. 
10. A young couple come to your office to enquire about a holiday to Mexico (their first visit to that country). They are interested in booking reservations on a popular ITC package tour and ask your advice as to whether the tour would suit them or whether they would be happier travelling independently.

From the passengers' point of view, name three advantages ITCpackages over FIT, and also state three advantages that FIT has over ITC. 
$\mathrm{V}$ UNIT 4: TECHNIQUES OF SELLING TRAVEL; HOTELS AND RESORTS

Unit 4 consists of ten lessons and a Unit Project. The following materials are needed in order to complete the unit.

1. Instructor's Notes

2. Principles and Procedures of Travel Counselling

UNIT 4: PROJECT

Create a Travel Agent modeled after one in your area and prepare a promotional campaign for a one year period.

The programme should include an account of all expenditure of time and money by the manager and staff of the agency. The programme should include advertising, publicity, human relations and staff training.

The project is to be completed over the period taken to do Unit 4. It is to be submitted with the last lesson. Marks will be given for the following:

1. description of Travel Agency

2. completeness of promotional campaign

3. aims of the promotional campaign

4. understanding of the expense of a promotional campaign

5. neatness and presentation 
TOPIC: Understanding the Client

OBJECTIVES: The student will have a basic knowledge of human psychology in the area of what motivates people; the student will link motivation to selling travel. REFERENCES: Principles and Procedures of Travel Counselling Pages 243 to 245 .

INSTRUCTOR'S NOTES :

Read Introductory paragraphs, page 245.

Before anyone attempts to embark on a sales career, they must appreciate the fact that their customers are people and in order to sell to them you must first be able to convince them to buy. A successful sales person must be able to select a product which matches his client's needs.

Read Section 1 .

The reason why a person thinks or acts in a given manner stems from a complicated mixture of inner urges. Furthermore, people with the same motives may respond to them very different. It is the duty of a good travel counsellor to read his client's motives and to match it to the rest of his personality.

A travel counsellor can partly mould his client's attitude by giving him the type of information to cause a positive response to suggestions. Many of the fears or doubts of the would be traveller can be set at ease by the informed counsellor. For example, by telling them that news stories of student demonstrations in Paris will not affect their holiday on the French Riviera. Travel agencies serve an important 
role in informal education and the travel counsellor is in a strong position to wield influence on a client's choice of destination, by giving him the necessary information to persuade him to buy one destination over another.

In a small community the travel counsellor can also keep tabs on some of the reference groups, especially organizations and clubs, which are likely to influence his clients, thereby being in agood position to understand their fears.

\section{ASSIGNMENT}

Lesson 1

1. What is the difference between a primary motive and a secondary motive?

2. List fifteen things which determine the fact that it is unreasonable to assume that people will act alike.

3. There are eight primary and nine secondary motives listed in the text. List two holiday destinations which would satisfy each of the motives and give a reason for each. 


\section{LESSON : $\quad$ TwO}

TOPIC: Salesmanship

OBJECTIVES: The student will differentiate between the three types of traveller encountered in direct sales:

-the specific

-the non-specific

-the uncommitted traveller

The student will know the different sales approaches required by each, and the basic information necessary to make a booking.

REFERENCES: Principles and Procedures of Travel Counselling. Pages 245 to 249 .

INSTRUCTOR'S NOTES :

Read Section 2, page 245 .

The specific prospect is the easiest sale usually requiring only a minimum amount of the travel counsellor's time. However, the student should note that opportunities do arise to increase the sale as well as enhance the image of the agency. No sale is too small or straightforward for the counsellor not to give thought to ways of easing the client's burden. while making a bit more income.

The non-specific prospect is very typical of many holiday makers who have been exposed to travel sections in the newspaper or who have read travel guide books. Their appetite has been whetted and they are looking for direction. Here is the situation where the counsellor must read the motivation forces and influences such as finance, which are affecting this particular client. It many require considerable discussion and several 
suggestions may be made before the would-be traveller selects one. One very good method of advising is for the counsellor to be able to say "Iwent there myself". For this reason the working counsellor will try, once or twice a year, to make a familiarization tour (Fam Tour) to get first hand knowledge of popular destinations. This sales aid is sponsored by national tourist organizations, national air carriers, hotel associations and other interested groups.

The uncommitted prospect, even if this person never goes anywhere but merely comes in to collect an armful of literature, remember that all is not lost, through him it may come to the attention of someone else who is genuinely interested in travelling! Tourist literature is free and the more brochures which leave the travel counsellors desk, the more likely the chance of being seen by other prospective travellers. Brochures which sit in an agent's rack are of no value.

Read Section 3 .

Always bear in mind that vacations are meant to be HAPPY events in the life of your client, when you smile you invoke the promise of happy times and you put the client at ease. SMILE AND BE CHEERFUL, they are important!

The basic formula for the information you should obtain from your client is:

WHO will be in the party
WHAT price range
WHEN can they travel
WHY or what are the motives
WHERE would they like to go


Note the importance of LISTENING to your client, it will sometimes happen that he will ask you a question to clarify his own thoughts before he can answer your question. It has been said, with justification, that two thirds of the sales process is listening:

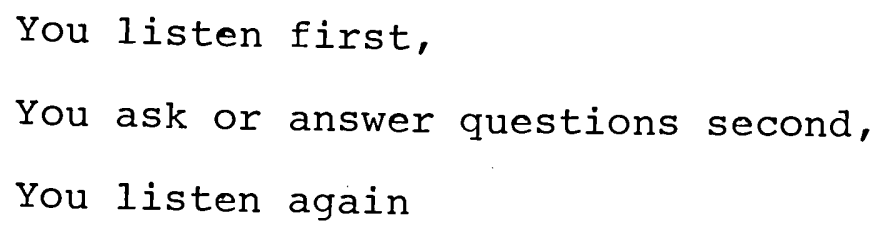

Avoid interrupting your client, neither of you will hear what the other has said. And avoid butting in if he is studying your proposals or brochure and trying to decide, interrupting his train of thought will not speed the sale. Indeed, it is a good technique to ACTIVELY INVOLVE your client in the consultation of brochures because it gives him the feeling that he has helped to make the decision, therefore it must be right.

Travel brochures have been designed at great cost to help sell travel. Use them, but do not confuse the issue by using too many of them.

When you begin quoting prices, be absolutely sure that you are quoting the correct prices. Where there are conditions which affect the price such as advance purchase, the client must be informed. If your client requests flights on a specific airline, it is still your duty to inform him if more convenient connections or non-stop routes are available by other carriers and let him decide.

Finally, you should bear in mind, that, by the technique of putting yourself in your client's shoes, you could demonstrate your interest and understanding. One must never use tech- 
nical jargon which means a lot to you but leaves the client bewildered and does not help to sell.

\section{$\underline{\text { ASSIGNMENT }}$}

Leseon 2

1. Counsellor: Good morning Sir, may I help you?

Client: Yes, I was passing your window and saw the advertisement for the cruise to Greece. I would like to book seats for myself and family.

What information should the counsellor then seek from the client?

2. The counsellor then proceeds to book the cruise to Greece for the client. What other action could he have taken Lefore making the booking? Give reasons for your answer.

3. A customer has returned from a trip abroad and complains to you that his return flight was delayed five hours and it caused him to miss an important business appointment. Write what your reply would be, using the first person in the present tense. (your direct reply to him)

4. You have been talking with a prospective client and have obtained a good idea of his travel desires. You mention a tour which he seems interested in, but when you inform him of the price he states it is too expensive. How would you react to this?

5. You have offered a prospect an F.I.T. and he is very impressed. However, when you mention that the total cost must be prepaid in advance, he askes that he be 
permitted to pay for the hotel as he travels. What would be your reply.

LESSON: $\quad$ Three

TOPIC: Telephone Sales

OBJECTIVES: The student will be able to use the telephone to sell travel and maintain good customer relations. REFERENCES: Principles and Procedures of Travel Counselling pages 249 and 250 .

INSTRUCTOR'S . NOTES :

Read Section 4 .

The most important thing to remember about telephone sales is that your voice becomes your personality and you have not selling aids to lean on. No brochures. No smiles, no wellgroomed appearance. Only your voice.

What the travel counsellor must attempt to do, in the cases of the non-specific or uncommitted prospective client is to try and get him into the travel agency where the other sales techniques can be used. You need to generate enthusiasm and make the caller want to come to your office. Tell him who to ask for (also that anyone in the office would be happy to assist him). And try to get the basic facts about his query so that you can immedicately start off his visit on a more personal basis.

Some of the things you should try to do in a telephone conversation are:

1. Listen 
2. Answer the telephone as soon as it rings.

Do not make the caller wait while it rings

on and on; and once you have answered, do not go shuffling off to find information while having him hold a silent line for countless minutes.

3. If your search for information will time consuming, suggest you call back which means you get the caller's number. And remember to call back as promised.

4. In cases where you have already got a personal caller seated at your desk, still give the telephone call priority. Say a polite "Please excuse me", remember that the seated client is already in your office. The telephone caller you have yet to reach.

Read Section 5 .

\section{$\underline{\text { ASSIGNMENT }}$}

Lesson 3

1. "Courtesy, service and a willingness to please are the distinguishing attributes of a travel agency whose clients retujnn again and again." Give an example of each of these factors in telephone sales and discuss fully the merits of your examples.

2. What are five irasic points to remember, when making telephone sales? 
Make a recording of your normal speaking voice by recording section 4 , page 249. Listen to how it sounds. Make critical remarks about its tone, clarity, speed, manner, enthusiasm, as you hear it. Rehearse the phrases of greeting, regret and closing a sale. You may need to repeat this exercise if at first you do not feel relaxed using a tape recorder. 
LESSON : $\quad$ Four

TOPIC: $\quad$ Product Knowledge and Success in Sales

OBJECTIVES: The student will take steps to acquire sound knowledge of travel products and use it to make an imaginary sale.

REFERENCES: Principles and Procedures of Travel Counselling Pages 250 to 252 .

INSTRUCTOR'S NOTES :

Read Section 6, page 250 .

To back up the techniques of making a sale, the travel counsellor must know what he is selling and understand the motives of people.

The importance of KNOWING YOUR PRODUCT cannot be overemphasized and the student must spend as much time as possible to acquire a working familiarity with places, names, events and conditions around the globe. To acquire this knowledge you must be highly motivated, wanting to find out for the sheer interest of knowing.

Read extensively. Keep your eyes and ears open, in the subway, walking along the streets, flicking through books or magazines, reading advertisements. All of these are informal ways of acquiring information.

Note, however, that in addition to absorbing facts the travel counsellor must be able to assess them. Some important facts may come to your notice indirectly, a line in a news story that an oil slick has been located near to a popular seaside resort, this could have a serious effect on your client's heading there. 
One way to obtain a sound knowledge of the globe is to sit with a political map of a region or continent and simply read it. Read the names. See where familiar places are, see how they relate to unfamiliar places.

Another method is to put up a large world map on the wall of your study area in such a position that you see it frequently. You will be surprised at how samll the world will become, how familiar the names sound in a short time!

Once you have acquired a familiarity with places and names then you can set about putting this knowledge to use! You can combine it with knowledge of other things such as schedules, and you will arrive at the product knowledge needed to counselL. Similarly, by frequently referring to cruise brochures showing deck plans and tariffs you will become used to the phraseology used and obtain skill in reading a deck plan.

In short, KNOWledge is the basis for counSELIING.

\section{ASSIGNMENT}

Lesson 4

1. Draw up two lists of sources of informtion about destinations. (One list to consist of printed sources of information; the other list to be of sources of all other types of information).

2. You have had several requests recently for travel arrangements to Australia. Describe how you would attempt to gain information about Australian tours and tour operators. 
LESSON :

\section{Five}

TOPIC :

OBJECTIVES

Travel Promotion and Public Relations

The student will understand the elements of a promotion campaign; how to use advertising, publicity and human relations to increase the public image of his travel agency.

REFERENCES: Principles and Procedures of Trave; Counselling. Pages 252 to 256 .

INSTRUCTOR'S NOTES :

Read Section 7 page 252 .

Promotion: All promotional activities are aimed at increasing the acceptability and use of the products being promoted. Thus, individual countries promote their interest by holding Familiarization Tours for aqents by slide and pictoral displays and most commonly by distributuion of advertising brochures. The travel counsellor in turn uses these promotional aids to obtain the informtion needed to sell travel to his clients. Very often there is a wholesaler who organizes package tours on a wholesale basis which is then sold by the cousellor in his retail trade. They all aim to increase business and sales. Advertising: It is very costly. It therefore needs to be budgeted for and a plan of execution of the campaign must be drawn up. It is costly and wasteful to undertake sporadic, unplanned advertising. The other element involved is measurement of the success of the advertising campaing, usually the cost of the campaign as compared with the sales resulting from it. Many different techniques can be used to arrive at an estimate of how many callers resulted from advertising: 
-by asking the client derectly

-by using reply coupons in the press

-by asking clients to quote a particular reference

Publicity: It is the well-timed, well written news story can be a big seller over the paid advertisement simply because many readers "blank" their minds and do not see or read advertisements. However, the newspaper earns most of its revenue from sale of advertisement space and will certainly not fall for a "story" which is just a disguised advertisement! A news story must have some significant news of interest to readers. The travel counsellor who thinks he has a genuine news story could write down the basic facts on paper and call the newspaper office where newsmen will do the story.

Human Relations: There is one kind of advertisement which is unbeatable. It is the "word of mouth" or personal recommendation. A client who has had a fabulous holiday will not stop thinking or talking about it, he will tell his family, his fellow workers, his friends and evern casual acquaintences. To the travel agent, it is good and it is free, it cannot be measured and it cannot be bought.

\section{$\underline{\text { ASS IGNMENT }}$}

\section{Lesson 5}

1. Examine the scope and limitations of travel promotion through mass advertising as opposed to word of mouth comments of a client.

2. Describe the image a travel agency would try to project if it was selling, in the main, Inclusive Tour Charters and 
Advance Booking Charters.

3. What is the most effective mass media used by the travel agent? Explain the reason for your choice.

4. What are the differences between publicity and advertising? 
LESSON :

$\operatorname{six}$

TOPIC: The Hotel Jndustry

OBJECTILES: The student will know the history and background of the hotel industry and be able to distinguish between different types of hotels.

REFERENCES: Principles and Procedures of Travel Counselling. Pages 209 to 211.

INSTRUCTOR'S NOTES :

Read Section 1 page 209.

A hotel is regarded as a "home away from home" and the rapid development of hotels in the last 200 years has been directly due to the need for weary travellers to find a home away from home whether they travel for business or pleasure.

Read Section 2 .

The tourist or business visitor spends a large amount of money on his hotel accommodation and sometimes a considerable amount of his time! Therefor the travel counsellor must protect his client by being certain of the quality and type of hotel accommodation he recommends.

Read Section 3 .

For convenience, hotesl can be classified. Remember, however, that classifications are only descriptions and do not imply restrictions on the type of clientele. For example, a commercial hotel will accept a guest on a three week stay as well as a guest on an overnight business stop. One distinction arising from the difference in clients at a commercial hotel from a resort hotel is that guests will use the commercial hotel very little but may spend all day in or near a resort 
the resort hotel. Consider the airport hotel as compared with the ski lodge resort.

One generally approved way of assessing a hotel is to judge the EXTRAs which it provides, swimmingpool, tennis courts, dining rooms, shopping facilities, and night entertainment.

Resort hotels are often self contained areas where the guest may find all he wants right on the premises so he may never leave the hotel! It requires good variety in what the hotel provides because guests spend one or two weeks at a single hotel. By arrangement some hotels agree to allow their guests to use each other's facilities thereby increasing the amenities available and increasing guest satisfaction.

\section{ASSIGNMENT}

Lesson 6

1. List five hotels which could be classified as:
a) Commercial
b) Resort
c) Combination

2. List ten hotels in your area and state the chain or group to which they belong.

3. Using travel vouchures, list five resort hotels and their location which fall under the following sub-classifications:
a) summer resorts
b) winter cold resorts
c) winter warm resorts
d) year-round resorts 
LESSON :

Seven

TOPIC:

Hotel Rates and Deposits

OBJECTIVES: The student will be able to read hotel tariff sheets, interpret additional charges, meal plans and deposit policies.

REFERENCES: Principles and Procedures of Travel Counselling Pages 211 and 212,221 to 236 .

INSTRUCTOR'S NOTES :

Read Section 4, page 211

Hotel rates may vary with:

a) Type of Hotel - luxury, first class

b) Type of guest room - delux, standard, cottage

c) Provision of amenities - T.V., bar facilities in room, sun lamps, telephones

d) Location in Hotel - beach view, courtyard, near swimming pool

e) Location of Hotel - city centre, beach front

f) Number of occupants - single, double, triple

g) Seasonality - peak, low, shoulder.

Note well that a hotel sells NIGHTS or beds. Thus in the hotel world a guest stay is calculated as 7 nights and not 8 days in the period March lst to 8 th. Be very careful in calculating room charges for your client, and do not be deceived by the advertisements offering 8 glorious days and 7 enchanting evenings.

The student counsellor must also be vẹry careful in reading tariffs:

- note the currency quoted 
- note charges such as "extra person" and at what stage it applies

- note what meals if any are included

- note if the rate is per room or per person.

Study extensively the tariff sheets shown on pages 221 to 236 .

Read Section 5:

A deposit (pre-paid money) serves as guarantee that the guest will arrive at the hotel and that the hotel will keep a room for the guest. There are individual variations to hotel deposit policies designed to suit the needs of the hotel, and clauses concerning cancellation at the last minute.

Read Section 6:

Often the printed hotel tariff will NOT include service charge or local taxes because it increases the price figure. The travel counsellor must be on the lookout for this, the tariff will specify what is included in the price.

Read Section 7:

Most hotels provide restaurant service, some include one or more meals in their tariff.

The abbreviation used are fairly standardized:

EP European Plan, -no meals, room charge only
CP Continental Plan, -room and breakfast
MAP Modified American Plan, -room, breakfast
and dinner
AP American Plan, room and all meals.


Lesson 7

Consult the tariffs on pages 221 to 236 in Principles and Procedures of Travel Counselling.

1. Which hotels have already added service charges and taxes to their tariff?

2. Make a list of the various descriptions of rooms which are given in the tariffs.

3. What meals are included in Hotel Edison rates?

4. Are meals included in Hotel Ambassador rates or individual bookings?

5. What would you pay for a room, superior twin on MAP during the winter season at the Jamaica Pegasus? Calculate the service charge and Government tax, using both currencies.

6. Calculate your client's bill for a one night stay at Hotel Neptune in single accommodation no meals. How much will he pay in addition if he took all meals? If your client checks in at 1:00 PM on March 5th and checks out March 12, at 11:00 AM how many nights will he have stayed? How much will his bill total at the end of his stay if all meals, service charge and taxes are added?

7. Based on the Elbow Beach Surf Club information and rate sheet, specify the following:

a) for a group totalling 45 persons, how many free adults will be accommodated?.

b) What is the total deposit requirement for the booking arriving April 30th, leaving Mary 6th? 
c) What is the minimum number of rooms needed?

d) Calculate the total charges for ONE day for the group, include room, gratuities and tax.

e) Calculate the agent's commission on a day's charges.

8. What does Hotel Villa San Michele charge for 2 persons in a double with bath (DWB) with breadfast and dinner?

9. What is the charge (specify currency used) for a single room only without meals at the Barbados Holiday Inn during July. 
TOPIC :

Hotel Standards, Grading and Quality

OBJECTIVES: The student will distinguish the classes of hotels and judge the quality of a given hotel.

REFERENCES: Principles and Procedures of Travel Counselling Pages 212 to 214 .

INSTRUCTOR'S NOTES :

Read Section 8 , page 212 .

Classification systems vary from country to country. In some countries they are legally established grades, in others they are only voluntary guide lines. Variety also exists in designation of grades:
Alphabetic $-A, B, C, D, E$
Stars
-5 star, 4 star etc.
Categories
-Delux, First Class, Tourist
Location
-City, Airport, Douwntown

Combinations of designations.

In the WTO (formerly IUOTO) classification, the caregoriesstylè grading is recommended. Amenities and facilities and quality of staff are the broad criteria for grading. A sponsored tour to familiarize themselves with the total tourist picture of a destination will give counsellors the true picture of how classification actually works in the area. A grading check can be done on the tour.

Read Section 9. 


\section{ASSIGNMENT}

\section{Lesson 8}

1. Select two dissimilar hotels in your area. Compile a checklist that you would use if you were visiting hotels on a familiarization tour.

2. Arrange with the hotel management to inspect the hotel and talk with him.

Write a report on your findings at each hotel.

Submit for marking:
a) The hotel checklist
b) The report on each of the hotels. 
TOPIC :

\section{Hotel Reservations and Commissions}

OBJECTIVES: The student will know the information needed to make a reservation for an individual or group, how to use a hotel representative, and the conditions on which commissions are payable.

REFERENCES: Principles and Procedures of Travel Counselling Pages 214 to 217 .

INSTRUCTOR'S NOTES :

Read Section 10, page 214 .

The travel counsellor interprets his information about the hotel for his client. In turn, the client selects according to his taste and requests the counsellor to make a reservation or booking for him. It is crucially important that in conveying the client's request to the hotel that the counsellor is ACCURATE and SPECIFIC.

The hotel must be informed of the following:

a) Date and time of arrival

b) Length of stay, give actual dates to be certain no error arises

c) Name of guest

d) Number in party

e) Accommodation required, be specific, mentioning choice of room type, rate, view etc.

f) Special Needs, especially where the hotel may need to pre-plan, such as a special diet.

g) Name of Cousellor and Agency handling reservation The counsellor must wait for a reply from the hotel before 
he can confirm the reservation for the client. If the hotel can confirm the reservation for the client. If the hotel can fill the request they will reply stating what they are confirming. If they cannot supply the requested room type they will make an alternate offer, which must then be conveyed to the client who has the choice of taking it or rejecting it. Where time is running short a cable or telephone call might be needed, sometimes at a cost to the client, so this must be explained to him.

Read Section 11.

With the integration of hotels and airlines, shipping or rail companies, more efficient and speedy systems have been developed using telecommunications which process data fed to a central reservations clearing house. In minutes a request can be made, confirmed and relayed to the client, at no extra cost.

Read Section 12 .

Hotel Representatives are agents for specific hotels. They will only sell the hotels they represent and of course many hotels do not have a representative. The advantage of using a representative is that they are in close contact with their hotels and counsellor can be spared the slowness of mail services in remote resort areas, by dealing directly with the representative.

Read Section 13.

The counsellor with imagination and a flair for organizing groups can do good business with group bookings, even if room charges are not commissionable. Increasingly hotels are seek- 
ing convention group business, especially during their slack period.

Read Seztion 14.

Although the standard commission paid to travel agents is $10 \%$ there are variations above or below that figure. One snag which may hinder payment of the agent's commission is inconsistency between the agent's voucher and what the guest has run up on his bill.

The Voucher or Coupon

1. When a client books and pre-pays for the services he needs on his travels, he is issued with a receipt stating what he has paid for. When he arrives at the service point (hotel, sightseeing tour) he exchanges the relevant receipt or voucher for the service. This is his payment. It is now left to the hotel or tour operator to submit his claim for payment, less commission.

2. Alternatively, the voucher may be a part-payment such as a deposit. to guarantee a room reservation. In this case the agent has already forwarded the sum of money which the hotel will put to the credit of the guest's account. After services have been rendered to the value of the deposit, the guest begins to accumulate charges which he will pay the hotel.

Confusion can arise where the hotel, in the case of 1 above, erroneously omits to collect direct from the guest any incidental services not covered by the voucher, ie. telephone, laundry, bar. Or if the guest paid for accommodation only, the hotel 
may overlook meal charges then attempt to collect from the agent.

It is extremely important to state specifically what the voucher payment covers. In the event of a misunderstanding with the hotel the agent could use his good office with the guest to try to obtain the amount, in the interest of having good relations with the hotel.

\section{ASSIGNMENT}

Lesson 9

1. Why is it necessary for the counsellor to go over the voucher with his client?

2. You client request you to reserve a room for himself and his wife with breakfast and dinner included in the price. Which of these codes signify his needs? BS CP MAP B\&B D AP DP EP IstCl.

3. What essential information is needed to book a room for a client?

4. State whether these statements are true or false.

a) A request for a reservation is a confirmation of a booking .

$$
\text { TRUE }
$$

FALSE

b) Hotel representatives sell rooms for all hotels. TRUE FALSE

c) Usirg a hotel representative means an agent will get the room he wants. 
d) All group bookings for a hotel are commissionable. TRUE FALSE

e) A voucher does not represent payment of any sort. TRUE FALSE

5. You have been asked to quote rates for the following group at the Barbados and St. Kitts Holiday Inns (use information on page 236). The group consists of 12 double rooms and 6 singles for a total of 30 persons. They want the best accommodation on the Modified American Plan. They will be staying 7 nights.

Prepare your answer as if you were presenting it to the group organizer.

6. Prepare an organized visit for 45 students to the Elbow Beach Surf Club (use information, page 224).

This preliminary preparation because of a telephone inquiry resulting in an appointment with the organizer. Prepare the information you will present to the organizer. You will have to make some assumptions, note these on the presentation. 
LESSON : Ten

TOPIC: $\quad$ Hotel Terminology

OBJECTIVES: The student will use hotel terminology, realize the significance of hotel procedures and appreciate the need for good working relations with hotels.

REFERENCES: Principles and Procedures for Travel Counsellors Pages 217 to 219 .

INSTRUCTOR'S NOTES :

Read Section 15, page 217

As with all job titles there are variations from place to place, however the job functions are similar and the counsellor will soon recognize them.

The main departments in a hotel are:

Accounts Office

Front office - reservations and reception

Food and Beverage - Restaurant, Banquet and Bars

Sales and Marketing

Kitchens

Housekeeping

Engineering

Security

Read Section 16

The travel counsellor needs to be acquainted with hotel terms if he is to negotiate with hoteliers. Areas of special concern include terms used for meals, tariff structure and room types.

Read Section 17 . 
Many hotels will be flexible with guests whose check out or check in times vary from the hotel's desired times. However, it cannot be counted on and the client may feel harassed if he must sit and wait two hours in the lobby before seeing his room.

Read Section 18 .

A good travel counsellor is a person who perceives human behavior and works with it. He works with clients, transportation services and hotels. Clearly the benefits of cooperation will go to both parties and it is futile to be at loggerheads with your principals. Just as the word gets around about tiresome airlines or hotels, so too a tiresome agency becomes known and business will decline.

Read Section 19.

Obtain access to copies of the major reference manuals. Consult them and acquire a working acquaintence with each. One method of doing so is to consult the same topic in all the manuals, noting differences in information, ease of use, etc.

\section{$\underline{\text { ASSI GNMENT }}$}

Lesson 10

1. Define these terms:
a) Concierge
b) Continental breakfast
c) Pre-registration
d) Hospitality Suite
e) Run of the House
f) Rack Rate 
2. What is the purpose of a hotel check out time? Are they the same at each hotel?

3. What are six areas where cooperation with hotels will help maintain good working relations between a travel agency and a hotel?

4. What is the difference between an "a la carte" and "table d'hote" menu"?

5. Submit your Unit 2 and Unit 4 Project with this assignment. 
1. Using the accompanying Hilton International rate schedule, determine the following; be sure to show all calculations:

a) At the Kensington-Hilton, London, England, what is the total in Pounds sterling for a top-rate TWB including $\mathrm{s} / \mathrm{C}$ and taxes, check-in February 26, 1975; check-out March 02, 1975. No meals.

b) Minimum rate triple at the Jerusalem-Hilton with continental breakfasts (CB), check-in May 14, 1975, check-out May 16. Total shoüld include service charges and should be in Israeli Pounds. c) Show commission earned on (b) above.

2. a) Name five initial questions which must always be asked of prospective clients to enable you to properly counsel them.

b) Describe "selling-up" or up-grading. What does it mean? Name three ways you can try to sell-up.

c) Closing the sale has been described as getting the prospective client to make a definite booking with you. State three ways one can try to close a sale.

d) Specify what you believe is wrong in the following examples as spoken by a travel counsellor to a prospective client:

i) "You're thinking of a holiday in Mexico? Well, here's a bunch of folders you can look through. 
U.S. $\$ 1.00=14.00$ Room

Prices

nd

London, England

KENSINGTON HILTON

U.S. $\$ 1.00=.42$

CB 2.10

AB 2.90

1. 4 ns
D. 5.95

Turkish Lire

Jan. 1. 1974.Mar. 31.1975-E.P. Room Only

$\begin{array}{llll}\text { Single } & 19.05 & 20.25 & 21.40\end{array}$

$\begin{array}{lccc}\text { Single } & (23.55) & (2500) & (26.50) \\ \text { Double/Twin } & 2500 & 25.20 & 2735\end{array}$

Double/Twin $2500 \quad 25: 0202735$

\begin{tabular}{|ccc|c|c|} 
Oouble/Twin $(30.90)(32.40)(33.851$ & - & 06.55 \\
\hline Pounds Sterting & -
\end{tabular}

Jan. 1. 1974-Mar. 31, 1975-E.P.Room Oniy

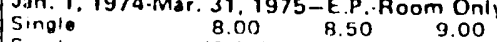

$\begin{array}{llll}\text { Single } & (9.90) & (10.51) & (11.14)\end{array}$

\begin{tabular}{llll} 
Oouble/Twin & 10.50 & 11.00 & 11.50 \\
Oouble/Twin 112.991 & 113.611 & 114.231 \\
\hline
\end{tabular}

Foom Rates in Parenthesis inclucte $12^{\prime},{ }^{\circ}$, Service Charge Plus 10\% Adred

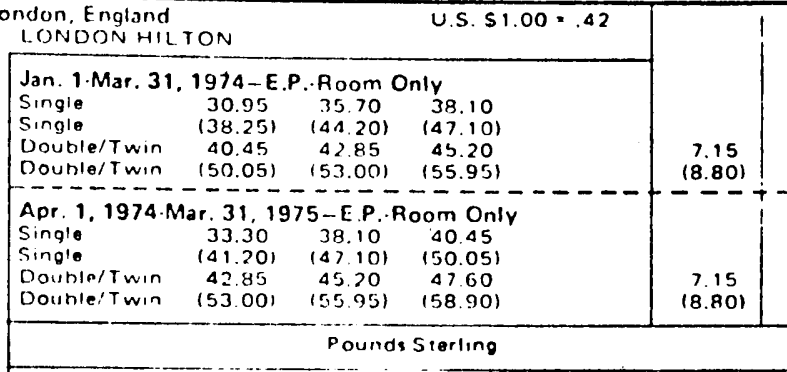

Jan. 1.Mar. 31, 1974-E.P.Room Oniv

Single $\quad 13.00$ 1500 16.00

Single $(15.08) \quad 1857) \quad(19.80)$

$\begin{array}{lccc}\text { Double'Twin } & 17.00 & 1700 & 19.00 \\ \text { Doubla/Twin } & (21.03) & (22.27) & (23.501\end{array}$

Apr. 1. 1974.Mar. 31. 1975-E.P.Poom Only

Single $14.00 \quad 16.00 \quad 17.00$

Single $\quad(17.32) \quad(19.80) \quad(21.03)$

$\begin{array}{llll}\text { Doubig Twin } 18.00 & 18.00 \quad 2000\end{array}$

Double/Twin (22.27) $(23.501 \quad(24.75)$

CB.0.85

AB. 1.35

0.2.75

C. 2.85

0.35
1.70 .35

D 10.35

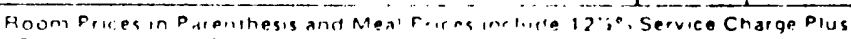
10 Arsiest Villio 1 ind

\section{Luxor, Egypt, U A.R}

MS. ISIS. MS (1)

E.P.Poom Oniv

Single 7.00

CB 0.65

Dowile/twin 8.15

The N.S. Isis and the M.S. Csirs overale ien ild, cruise schedules berween Luxor occupiaj one exira inght betore and one extra night atter inecruise. Rates are shown above

- Flus 5\% Tax dirrina Winier Season and 10 " Service Charge.

Tourst Rate av walite when hoipl inarges are oald in converteble currener Normal ronversiontale US. Si 0039.

\begin{tabular}{|c|c|c|c|c|c|}
\hline $\begin{array}{l}\text { Room Only } \\
\text { ile } \\
\text { itie'T win }\end{array}$ & $\begin{array}{l}20.55 \\
25.50\end{array}$ & $\begin{array}{l}24.25 \\
29.20\end{array}$ & $\begin{array}{l}28.00 \\
32.90\end{array}$ & 4.95 & 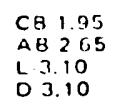 \\
\hline \multicolumn{6}{|c|}{ Molarsian Dollara } \\
\hline $\begin{array}{l}\text { Anom Only } \\
\text { yle } \\
\text { fblo/Twin }\end{array}$ & $\begin{array}{l}50.00 \\
62.00\end{array}$ & $\begin{array}{l}59.00 \\
71.00\end{array}$ & $\begin{array}{l}68.00 \\
80.00\end{array}$ & 12.00 & $\begin{array}{l}\text { CB.4.75 } \\
\text { A } .6 .50 \\
L .7 .50 \\
0.7 .50\end{array}$ \\
\hline \multicolumn{6}{|c|}{ Room and Meal Prices Plus $10 \%$ Service Charge and $3^{n}$; Tax. } \\
\hline $\begin{array}{l}\text { Kuwait } \\
\text { WAIT HILTO }\end{array}$ & & & U.S. $51.00=.294$ & & \\
\hline $\begin{array}{l}\text { Room Only } \\
\text { Nole/Twin }\end{array}$ & $\begin{array}{l}2380 \\
34.00\end{array}$ & $\begin{array}{l}28.90 \\
37.40\end{array}$ & & - & $\begin{array}{l}C B \quad 1.55 \\
A B \cdot 2.55 \\
L \cdot 5.80 \\
D \cdot 5.80\end{array}$ \\
\hline \multicolumn{6}{|c|}{ Kuwait Dinars } \\
\hline $\begin{array}{l}\text { Anom Onlv } \\
\text { Wilo/Twin }\end{array}$ & $\begin{array}{r}7.000 \\
10.000\end{array}$ & $\begin{array}{r}8.500 \\
11.000\end{array}$ & & - & $\begin{array}{l}C B 0.450 \\
A B-0.750 \\
L \cdot 1.700 \\
D-1.700\end{array}$ \\
\hline
\end{tabular}

hoom and Meal Prices Plus 15 'n Service Charge

\section{Egvotian Pounds}

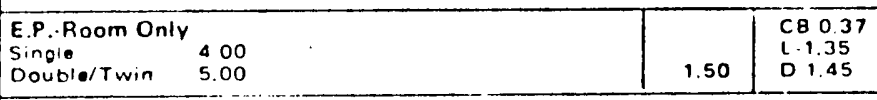

The M.S. Isis and the in, S. Osiris operate requiar cruise schedules betveen Luxor The Aswan Cruise tates shouvn at the bottom of this nage. The ships may be accubied one extra night netore and one extra night after the cruise. Rates are shown above.

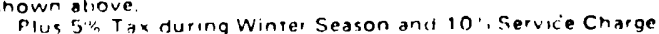

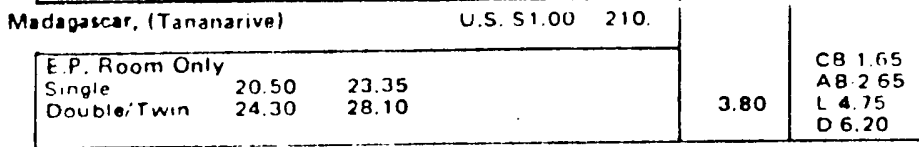

Beir

Egypt, U.A.R

U.S. $\$ 1.00=.57^{\circ}$

\section{ALL PAICES PER PERSON}

luxar-Dendara-Abvoos.Luxne - 3 nighes/4 dovs

Wror Aswan of Asivan.Lixor - 4 nighes. 5 dav.

uxor-Dendar Anvoos Luxor. Aswan or vice verso ... I nights/B anye

Molagasy Francs

\begin{tabular}{lll|l|l}
\hline E.P. Room Only & & & & CB 350 \\
Single & 4.300 & 4.900 & & \\
Double/Twin & 5.100 & 5.900 & 800 & L. 1.000 \\
1.300
\end{tabular}

All Room Prices Plue 10". Tax alld 10\% Service Charge.

All Meal P. os olu: 10\%, Service Change

\begin{tabular}{|c|c|c|c|c|c|c|}
\hline \multicolumn{6}{|c|}{ M.S. ISIS - M.S. OSIRIS - All Inclusive cruise rates } & \\
\hline \multicolumn{3}{|c|}{ Nov. 16 to Apr. 30} & \multicolumn{3}{|c|}{ May 1 to Nov. 15} & \\
\hline Single & Double & - Trinle & single & Dounle & Triple & \\
\hline $\begin{array}{l}174.50 \\
235.6 .0 \\
349.00\end{array}$ & $\begin{array}{l}122.15 \\
157.00 \\
235.60\end{array}$ & $\begin{array}{l}104.70 \\
13960 \\
13: \text { ro }\end{array}$ & $\begin{array}{l}157.00 \\
218.15 \\
314.15\end{array}$ & $\begin{array}{l}104.70 \\
148.35 \\
209.40\end{array}$ & $\begin{array}{r}96.00 \\
130.90 \\
174.50\end{array}$ & 1 \\
\hline \multicolumn{6}{|c|}{ mal conversion male U.S. $\leq 1.00-39$} & \\
\hline \multicolumn{3}{|c|}{ Nov. 16 to Apr. 30} & \multicolumn{3}{|c|}{ May 1 to Nov. 15} & \\
\hline Single & Double & Triple & Single & Double & Triple & \\
\hline $\begin{array}{l}100 \\
135 \\
200\end{array}$ & $\begin{array}{r}70 \\
90 \\
135\end{array}$ & $\begin{array}{r}60 \\
80 \\
110\end{array}$ & $\begin{array}{r}90 \\
125 \\
180\end{array}$ & $\begin{array}{r}60 \\
85 \\
120\end{array}$ & $\begin{array}{r}55 \\
75 \\
100\end{array}$ & \\
\hline
\end{tabular}


ii) "Those cabins on the Main Deck cost a fortune!"

iii) "We may have to book you on another carrier for the first leg of the trip because of availability, especially for F.I.T. passengers."

iv) "Bermuda is just fantastic at this time of the year and the Princess is fabulous and I know you'll find it really great."

v) "The weather in Casablanca in January? Oh, I think it is okay."

vi) "The minimum rate room for that hotel is $\$ 40.00$ and I'm sure you will find that it is good enough."

3. Define and explain as fully as you can the following industry terms:
a) Stopover (North American air travel)
b) Stopover (International Flight)
C) Minimum connecting time
d) Deni-pension
e) Hotel service charges
f) M.A.P.
g) F.I.T.
h) M.P.M.
i) Print fare
j) Porterage

4. "Up-grading" or "selling-up" is acceptéd practice in travel agencies as it is in most retail businesses. It does not 
mean using high-pressure selling tactics. Selling up means that after you determine what the prospective client really wants, you then make suggestions to increase the value of the client's enjoyment of his holiday trip. Specify four opportunities for selling-up.

7. Using the accompanying Hilton International Tariff sheet, determine the following, including any service-charges or taxes which might apply. All your calculations must be clearly shown:

a) Caracas-Hilton, 4 nights, minimum triple in U.S. dollars

b) Delux (best available) DWB at Curacao-Hilton, check-in April 17, 1976, check-out April 21, in Netherlands Antilles Guilders, modified American Plan.

c) Determine only the total commission earned in U.S. dollars by your travel agency on a booking for a group of thirty persons, all married couples, at the Caracas-Hilton, arrival June 5, 1976 for a stay of two nights. 


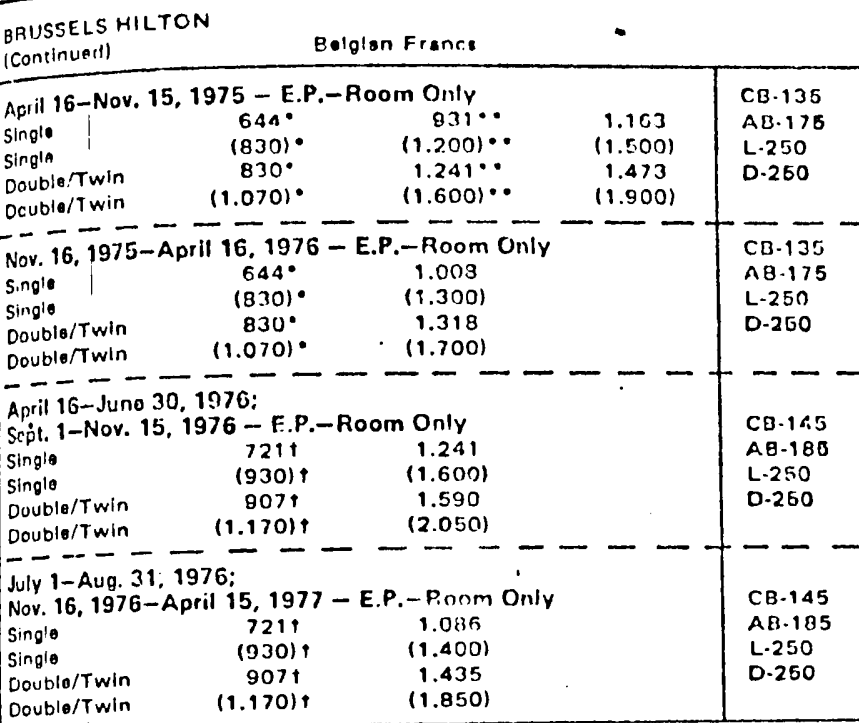

Room Rates in Parenthesis include 16\% Service Charge, 6\% Tox Plus 6\% Added Volve Tox.

- Rates avoilable Friday, Saturday and Sundoy, 1975.

- Availoble July and August, 1975.

i Rates ovailable Friday, Soturdoy and Sundoy, 1976

Cairo, Egypt, U.A.R.

U.S. $\$ 1.00=.585^{\circ}$

NILE HILTON

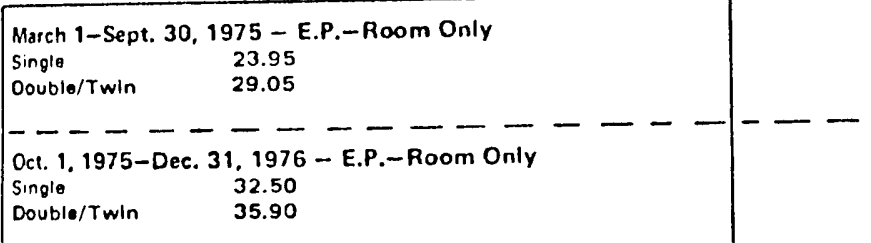

All Room Prices Plus S.09 Tox per person per day Plus 2\% Municipaliey Tox on Total Bill. All Room Prices Plus $10 \%$ Service Chargo.

- Tourist finte ovalinble when hotel charges ere paid in convertible currency. Normal conversion rate U.S. $\$ 1.00=39$.

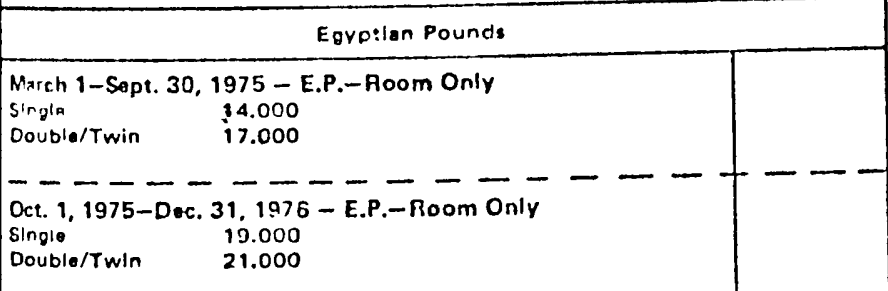

All Room Prices Plus Pt. 5 Tax per person por dav. Plus $2 \%$ Municipality Tox on Total Bill. Fates subject to Government Approval.

All Room Prices Plus 10\% Service Charge.

airo, Egypt, U.A.R.

U.S. $\$ 1.00=.585^{\circ}$

AIS ISIS* - A FLOATING HOTEL

Jan. 1-Doc. 17, 1975 - E.P.-Room Only

7.70

CB-.95

Double/Twin $\quad 10.25$

$-3.25$

D.3.85

Dec. 18, 1975-Dec. 15, 1976 - E.P.-Room Only

Single

3.70

Double/Twin $\quad 17.10$

All Foom Prices Plus \$.09 Tax per person per day, Plus 10\% Service Charoe.

Plus $2 \%$ Municipalley Tax on Total BIII

- Tourlst Hate avaloble when hotei chergas ere peld in converelble currency. Normal conversion rate U.S. $\$ 1.00-39$.

- For Aates on Crjises betwaen Colro-Luxor end Aowen - see Luxor.
M.S. ISIS- -A R.LOATING

HOTEL (Conilnued) Eavrien Pounds

Jan. 1-Dex. 17, 1975 - E.P.-Room Only

Singlo 4.500

CR.0.55

L. 1.905

D-2.245

- - - - - - - - - - - - - - - -

Doc. 18, 1975-Dec. 15, 1976-E.P.-Hoom Only -

Single R.000

Doublertwin 10.000

L.2.245

0.2 .805

All Room Prices Plus $\mathrm{Pe}, 5 \mathrm{Tax}$ per person per day, Plus $10 \%$ Servico Charge,

Plus 2\% Municipality Tax on Total Bill.

- For Rates on Cruises between Calro-Luxor and Aswan - see Luxor.

Canoda

Soe Montroal (2), Quebac Clty, Toronto, Vancouver.

Caracas, Vennzuola ; U.S. $\$ 1.00-4.20$

CARACAS HILTON

May 1-Sept. 30, 1975 - E.P.-Room Only

Single 26.20

\begin{tabular}{ll|l} 
Doublo/Twin & 32.15 & L-5.10
\end{tabular}

Oct. 1, $\overline{1975} \overline{\text { Dec. }} \overline{31}, \overline{1976}-\overline{\text { E.P. }} \overline{- \text { Room }} \overline{\text { Only }}----$

Single 28.60

Double/Twin $\quad 34.50$

L.5.10

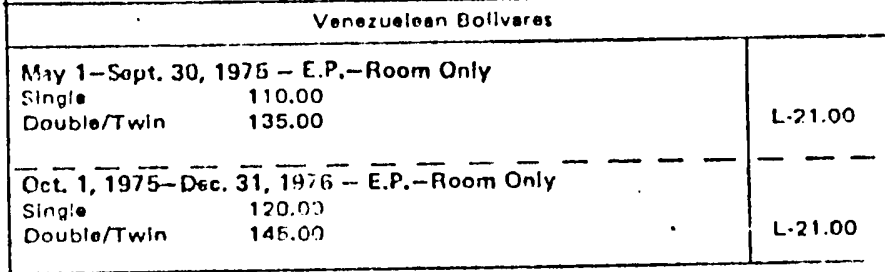

Colombia

Sce Rognte

Curacao. N.W.I

CUPACAO HILTON

April 16-Dec. 20,1975 - E.P.- Room Only

Single 21.00

Double/Twin 26.00

April 16-Dec. 20, 1975 - M.A.P.

Single $\quad 36.00$

Double/Twin $\quad 56.00$

Doc. 16-31, 1975; Feb. 1-29, $197 \overline{6}-\overline{E . P} .-\bar{R}$ - $\overline{\text { Rom Only }}$

Single $\quad 42.00$

Double/Twin $\quad 52.00$

Dec. 16-31, 1975; Feb. 1-29, 1976 - M.A.P.

L-7.00

Single $\quad 58.00$

Double/Twin 84.00

- - - - - - - - - - - - -

Jan. 1-31, 1976: March 1-April 18, 1976 - E.P.-Room Only

Single 36.00

Double/Twin $\quad \mathbf{4 5 . 0 0}$

Jan. 1-31. 1976; March 1-April 18, 1976 - M.A.P.

L-7.00

Single 62.00

Double/Twin $\quad 77.00$

April 19-Aug. 31. 1976

Oct. 1-Doc. 15, 1976 - E.P.-Room Only

Sinale 24.00

Double/Twin 29.00

Arril 19-Aug. 31, 1976:

Oct. 1-Doc. 15, 1976 - M.A.P.

Single $\quad 40.00$

Double/Twin , 61.00

- - - - - - - -

Sapt. 1-30, 1976 - E.P. - Room Only

$\begin{array}{ll}\text { Single } & 21.00 \\ \text { Double/Twin } & 26.00\end{array}$

Sopt. $1-30,1976$ - M.A.P. 